\title{
MARKET ASSESSMENT AND DEMONSTRATION OF LIGNITE FBC ASH FLOWABLE FILL APPLICATIONS
}

Final Report

By

Alan E. Bland

September 2003

Work Performed Under Cooperative Agreement

DE-FC26-98FT40323 Task 6

For

North Dakota Industrial Commission

Bismarck, North Dakota

Montana-Dakota Utilities

Bismarck, North Dakota

And

U.S. Department of Energy

National Energy Technology Laboratory

Morgantown, West Virginia 


\section{DISCLAIMER}

This report was prepared as an account of work sponsored by an agency of the United States Government. Neither the United States Government nor any agencies thereof, nor any of its employees makes any warranty, expressed or implied, or assumes any legal liability or responsibility for the accuracy, completeness, or usefulness of any information, apparatus, product, or process disclosed or represents that its use would not infringe on privately owned rights. Reference herein to any specific commercial product, process, or service by trade name, trademark, manufacturer, or otherwise does not necessarily constitute or imply endorsement, recommendation, or favoring by the United States Government or any agency thereof. The views and opinions of authors expressed herein do not necessarily state or reflect those of the United States Government or any agency thereof.

\section{ACKNOWLEDGMENTS}

The authors would like to acknowledge the U.S. Department of Energy, National Energy Technology Laboratory (DOE/NETL) funding, the North Dakota Industrial Commission (NDIC) funding through Contract No. FY97-XXVI-73, FY99-XXXIII-90, and the funding of the Montana-Dakota Utilities. The authors would also like to acknowledge the assistance of Dr. Kamalendu Das and Dr. Robert Patton of DOE/NETL and Mr. Clifford Porter of the NDIC. 


\begin{abstract}
Montana-Dakota Utilities (MDU) and Western Research Institute (WRI) have been developing flowable fill materials formulated using ash from the Montana-Dakota Utilities R. M. Heskett Station in Mandan, North Dakota. MDU and WRI have partnered with the U.S. Department of Energy (DOE) and the North Dakota Industrial Commission (NDIC) to further the development of these materials for lignite-fired fluidized-bed combustion (FBC) facilities. The MDU controlled density fill (CDF) appears to be a viable engineering material and environmentally safe. WRI is pursuing the commercialization of the technology under the trademark Ready-Fill ${ }^{\mathrm{TM}}$.
\end{abstract}

The project objectives were to: (1) assess the market in the Bismarck-Mandan area; (2) evaluate the geotechnical properties and environmental compatibility; and (3) construct and monitor demonstrations of the various grades of flowable fill products in full-scale demonstrations. The scope of initial phase of work entailed the following:

- $\quad$ Task I. Assess Market for MDU Flowable Fill Products;

- $\quad$ Task II. Assess Geotechnical and Environmental Properties of MDU Flowable Fill Products; and

- Task III. Demonstrate and Monitor MDU Flowable Fill Products in Field-Scale Demonstrations.

The results of these testing and demonstration activities proved the following:

- $\quad$ The market assessment indicated that a market exists in the Bismarck-Mandan area for structural construction applications, such as sub-bases for residential and commercial businesses, and excavatable fill applications, such as gas line and utility trench filling.

- $\quad$ The cost of the MDU flowable fill product must be lower than the current $\$ 35-\$ 45 /$ cubic yard price if it is to become a common construction material. Formulations using MDU ash and lower-cost sand alternatives offer that opportunity. An estimated market of 10,000 cubic yards of MDU flowable fill products could be realized if prices could be made competitive.

- $\quad$ The geotechnical properties of the MDU ash-based flowable fill can be modified to meet the needs of a range of applications from structural fill applications to excavatable applications, such as utility trench fill. 
- Environmental assessments using standard testing indicate that the environmental properties of the fill materials are compatible with numerous construction applications and do not pose a threat to either adjacent groundwater or soils.

- $\quad$ WRI developed an Environmental Field Simulator (EFS) method for assessing the impact of flowable fill materials on adjacent soils and found that the zone of impact is less than a couple of inches, thereby posing no threat to adjacent soils.

- $\quad$ Field-scale demonstrations of the MDU flowable fill were constructed and were successful for structural, as well as excavatable applications. Monitoring has demonstrated the geotechnical performance, environmental performance, and compatibility with common embed materials with the MDU flowable fill products.

Technical and economic issues were identified that may hinder the commercial acceptance of MDU flowable fill materials, including: (1) the ability to produce a consistent product; (2) the ability to provide a product year round (cold weather retards strength development); and (3) the ability to evaluate and produce commercial quantities of MDU flowable fill using inexpensive materials. These issues were addressed in the next phase of the project. The scope of work and results of this phase of this project are as follows:

\section{Product Variability and Product Service Environment Testing}

Testing examined the effect of MDU Heskett component variability and curing environment on the geotechnical properties of the resultant flowable fill. In addition, the effect of temperature conditions on the geotechnical properties was also examined. The flowable fill geotechnical properties were shown to vary with sand characteristics, ash characteristics, and even cement sources. Cold curing conditions were found to retard set development and unconfined compressive strength. However, a consistent product can be produced with proper control and management. The limitations on the placement of the flowable fill product under cold conditions will be similar to that of other concrete products.

\section{Construction and Operation of Ready-Fill Plant}

A commercial-scale batch plant was constructed at a site centrally located between two of the ready-mix concrete suppliers in Bismarck, North Dakota. The ash was transported from the Heskett plant by cement tanker and pneumatically delivered into the ash hopper. The fine sand was delivered to the site by truck and stockpiled on site. The batch plant was capable of producing truck-load quantities of Ready-Fill for the demonstration activities.

Demonstration and Monitoring of Commercial-Scale Application of Ready-Fill 
Seven commercial-scale demonstrations were conducted using a Ready-Fill product composed of waste sand, MDU fly ash, cement and water, and batched at the Ready-Fill plant in Bismarck and delivered to the site by local ready-mix concrete suppliers. Demonstrations centered on excavatable, structural, and niche applications for Ready-Fill.

WRI and MDU have entered into a joint venture to market Ready-Fill in the BismarckMandan area. Ready-Fill is wholesaled to the three ready-mix concrete suppliers in Bismarck for retail to contractors. The price of Ready-Fill is $\$ 30-\$ 35 /$ cubic yard compared to other commercially available fill materials in the area priced at $\$ 40-\$ 45 /$ cubic yard.

As a result of this project, new markets are commercially available for the ashes from the burning of lignite in fluidized-bed combustors. The state of North Dakota has benefited by establishing a commercial product for lignite-derived ash in flowable fill applications, thereby transforming a present waste product into a salable commodity in the construction industry and providing employment and economic growth. 


\section{TABLE OF CONTENTS}

\section{$\underline{\text { Page }}$}

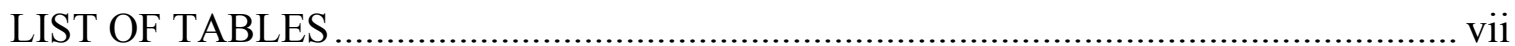

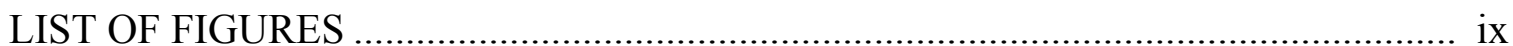

EXECUTIVE SUMMARY ...............................................................................

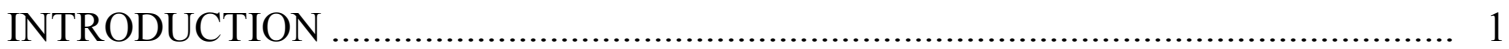

BACKGROUND OF FLOWABLE FILLS ........................................................ 3

RESULTS OF PRELIMINARY TESTING PROGRAM …....................................... 5

RESULTS OF FIRST TESTING PROGRAM ....................................................... 8

Results of Phase I - Market Assessment (Task 1) .............................................. 11

Results of Phase II - Laboratory Geotechnical and Environmental Tests

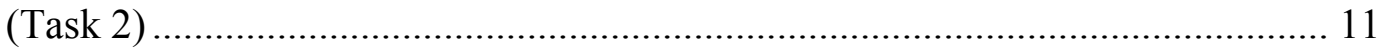

Results of Phase III - Demonstration and Monitoring Activities

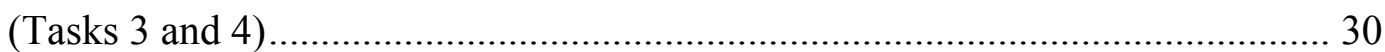

RESULTS OF SECOND TESTING PROGRAM ................................................... 49

Results of Task 1 - Product Variability and Product Service Environment

Testing .......................................................................................................... 51

Results of Task 2 - Construction of the Ready-Fill Batch Plant ......................... 54

Results of Task 3 - Commercial-Scale Field Demonstrations of the Ready-Fill

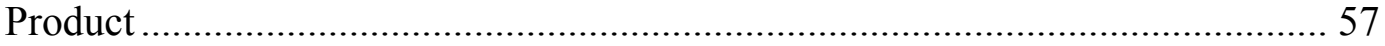

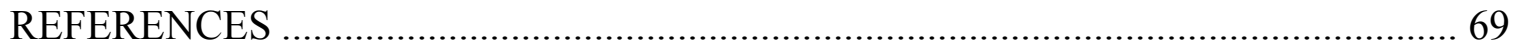

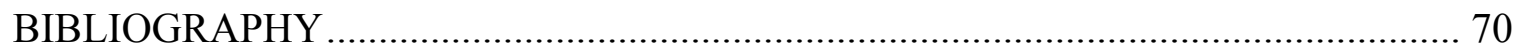

APPENDIX A. CHEMICAL COMPOSITION DATA ................................................. 74 


\section{LIST OF TABLES}

$\underline{\text { Table }}$

$\underline{\text { Page }}$

1. Typical Mix Proportions and Characteristics of Flowable Fill Materials

4

2. Summary of Performance of Structural- and Excavatable-Grade

Flowable Fill Material

3. TCLP Leachate Composition of the MDU Fly Ash and MDU and Conventional Flowable Fill Materials.

4. Major and Trace Element Composition of the MDU Fly Ash.............................. 13

5. Metals Ranges for Common Fill and Construction Materials .............................. 14

6. Comparison of the Mix Proportions of the MDU Flowable Fill and Mediumand Low-Strength Concrete

7. Set Time Characteristics of Structural-Grade and Excavatable-Grade Flowable Fill Material Cured Under Cold and Warm Conditions

8. Strength Development of Structural-Grade and Excavatable-Grade MDU

Flowable Fill Material Cured Under Cold and Warm Conditions

9. Strength Development of MDU and Commercial Flowable Fill

10. Effect of Air Entraining Agent (AEA) Addition to Structural-Grade MDU Flowable Fill On Freeze/Thaw Cycle Durability

11. Summary of the Results of the Wet/Dry Testing....

12. Free Linear Expansion Characteristics of MDU Structural-Grade Flowable Fill Cured Under Sealed and Wet/Dry Cycles at $23{ }^{\circ} \mathrm{C}$.

13. Major Element and Trace Metal Composition of the Heskett Fly Ash and MDU Flowable Fill Product 20

14. TCLP Extract Composition of the Heskett Fly Ash and MDU Flowable Fill Products

LIST OF TABLES (continued) 
15. Composition of MDU Ash and Flowable Fill Extracts Relative to U.S. EPA Water Quality Standards

16. Hydraulic Conductivity of Soils Adjacent to Rubblized MDU Flowable Fill Product Leachate 28

17. Mix Proportions for the Structural Fill Demonstration

18. Results of the Geotechnical Properties of the Structural-Grade Fill Materials Cured Under Different Curing Conditions

19. Mix Proportions for the Excavatable Fill Demonstrations

20. Geotechnical Properties of the Excavatable-Grade Fill Materials Cured Under Different Curing Conditions

21. Summary of the Strength of the Excavatable Fills After One Winter Season......47

22. Composition of Soils Adjacent to the Fills

23. Summary of the Composition of Heskett Ashes Taken Over Several Years 52

24. Curing Temperature Effect on Geotechnical Properties of Laboratory-Cured MDU Flowable Fill Specimens

25. Comparison of the Mix Proportions of the MDU Flowable Fill Materials and Medium- and Low-Strength Concrete

26. Summary of the Ready-Fill Leachate Composition per Modified (4:1) ASTM D-3987

\section{LIST OF FIGURES}


1. Photograph Showing the Flow Characteristics of MDU Flowable Fill Material ... 16

2. Schematic of the WRI Environmental Field Simulator

3. Chemical Impact of MDU Flowable Fill Product on Adjacent Soils from Environmental Field Simulator Tests 25

4. Schematic of the Rubblized MDU Flowable Fill Product Environmental Field Simulator Attenuation Tests

5. Chemical Effects of Rubblized MDU Flowable Fill on the Adjacent Soils Resulting From the Environmental Field Simulator.

6. Photographs of the Embed Coupons Before and After Being Exposed to Wet/Dry Cycling in MDU Flowable Fill

7. Photographs of the MDU Fly Ash Silo and Weigh System Erected at Atlas Ready-Mix for the Demonstrations ............................................................... 30

8. Photographs of the Rail Car Load Area Prior to the Demonstration Activities ..... 31

9. Site Layout for the Structural-Grade Fill Demonstration .................................... 32

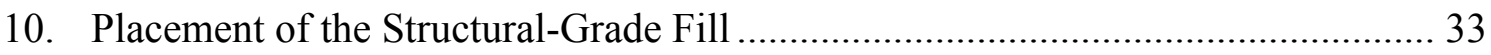

11. Placement of the Structural-Grade Fill ........................................................... 34

12. Setting of the Forms for the Concrete Pour ....................................................... 34

13. Concrete Pour at Structural-Grade Flowable Fill Demonstration Site ................... 34

14. Condition of the Structural-Grade Flowable Fill Twenty Hours After Placement. 35

15. Photographs of the Surface Cracks that Developed on the Structural-Grade Fill .. 35

16. Post-Construction Service of the Structural-Grade Fill Site 36

17. Collection and Testing of Flowable Fill Materials in the Field 37

LIST OF FIGURES (continued) 
18. Construction of the Trenches for the $30 \mathrm{E}$ and $60 \mathrm{E}$ Demonstrations

19. Construction of the Trench for the 10E200 Fill Demonstration 38

20. Construction of the Trench for the 10E200 Fill Demonstration 39

21. Photographs of the Embed Materials and Placement in the Demonstration Fills .. 40

22. Site Plans and Cross Sections for the Excavatable Fill Demonstrations

23. Photographs of the Placement of the 10E200 Flowable Fill Material at the Demonstration Site.

24. Monitoring of the Temperature of the 10E200 Flowable Fill After Placement

25. Collection and Fabrication of Test Specimens in the Field During the 10E200 Demonstrations

26. Ability of the 30E-Grade Fill to Support a Person After 16 Hours 45

27. Short-Term Performance of the 10E200-Grade Fill After 16 Hours 45

28. Excavation of the 60E Fill Demonstration 45

29. Excavation of the 30E Flowable Fill with a Toothed Bucket Backhoe 46

30. Photograph Showing the Cutting of the 30E Flowable Fill Material with a Toothed Bucket Backhoe.

31. Photograph of Pipe Embed Being Excavated From Flowable Fill 48

32. Comparison of Water Demand for MDU Flowable Fill due to Differences in Sand Characteristics

33. Strength Characteristics of Cements Used in Study 53

34. Ash Storage Hopper with Weigh Hopper 55 
Figure

$\underline{\text { Page }}$

35. Sand Hopper with Conveyor Belt ............................................................. 55

36. Placement of the Sand Hopper and Ash Hopper ............................................. 55

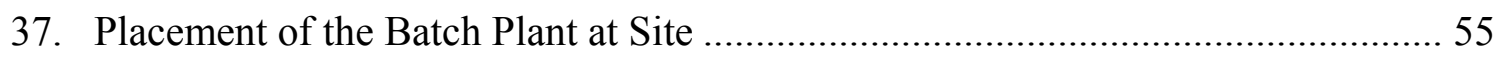

38. Assembled Ready-Fill Batch Plant in Bismarck, North Dakota .......................... 56

39. Photographs of the Batching and Loadout of the Ready-Fill Product ................... 59

40. E-Grade Ready-Fill Product Being Placed at Demonstration Site........................... 60

41. Pick-Up Truck Tire Track Indention on Excavatable-Grade Ready-Fill After

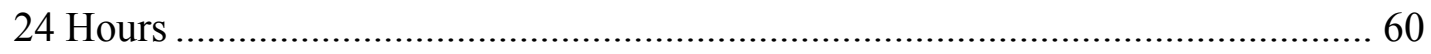

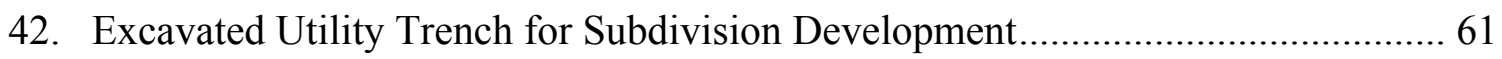

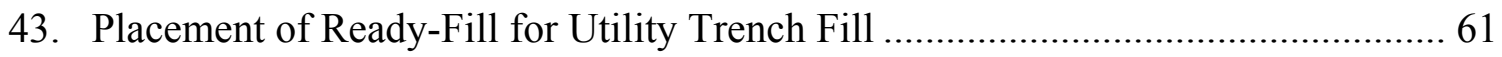

44. Photographs Showing the Placement of Ready-Fill as Part of the Main Street Repair Project in Bismarck, North Dakota ....................................................... 62

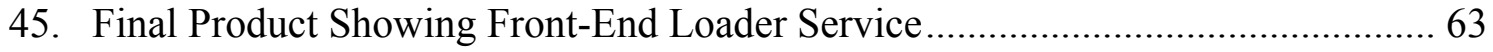

46. Photographs Showing the Location of the Ready-Fill Being Placed and the Final Work Area at the Heskett Station Second Demonstration................................... 63

47. WRI, MDU, and NDDH Personnel Examine the Performance of the Ready-Fill Base Material at the MDU Heskett Station During One of the Monitoring Visits

48. Placement of Ready-Fill at Krider Equipment Demonstration Site 64

49. Blade-Shaped Ready-Fill Storm Water Drainage 64

50. Monitoring the Storm Water Drainage Ditch Made From Ready-Fill at Krider Equipment

LIST OF FIGURES (continued) 
51. Retaining Wall at MDU Sweet Avenue Substation.................................... 67

52. Poured Ready-Fill Repair at the MDU Sweet Avenue Substation ................. 67

53. Photographs of the Use of Ready-Fill Product for Construction of a Bricked

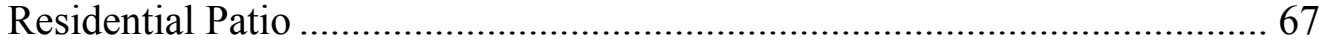




\section{EXECUTIVE SUMMARY}

Montana-Dakota Utilities (MDU) and Western Research Institute (WRI) have been developing flowable fill materials formulated using ash from the Montana-Dakota Utilities R. M. Heskett Station in Mandan, North Dakota, for use in a range of construction applications in the Bismarck-Mandan area. Flowable fill is a construction material that has a number of applications, such as removable backfills, structural fills, isolation fills, and trench bedding. Flowable fills have specified strengths ranging from 80 to 1,200 psi at 28 days, depending on the application. In addition, flowable fill has a slump of 9 to 10 inches and with certain formulations can be readied for traffic in 2 to 8 hours. Flowable fill is not a concrete, although it is in a flowable state at the time of placement. The flowable fill is usually mixed in a ready-mix concrete truck, and kept mixing during transport to prevent segregation of the aggregate. The material can be discharged by chutes or pumped using standard concrete or grout equipment.

An MDU-sponsored study yielded promising results and led to the current project cosponsored by the North Dakota Industrial Commission (NDIC) and the U.S. Department of Energy (DOE) National Energy Technology Laboratory (NETL). The objectives of this phase of the project were to: (1) assess the market for flowable fill in the Bismarck-Mandan area; (2) evaluate the geotechnical properties and environmental compatibility of the MDU flowable fill products; and (3) construct and monitor demonstrations of the various grades of MDU flowable fill material in field-scale demonstrations. The results of this phase are provided below.

\section{$\underline{\text { MDU Flowable Fill Market Assessment }}$}

A market assessment of the Bismarck-Mandan region for the MDU flowable fill material was conducted. The market assessment addressed the acceptability of the MDU flowable fill by contacting a number of potential consumers, such as local contractors, City of Bismarck engineers, utility company personnel, and ready-mix concrete suppliers to solicit their evaluation of the flowable fill market. Applications suggested for the flowable material ranged from structural applications, such as sub-bases for residential and commercial businesses, to excavatable fill applications, such as gas line and utility trench filling.

The current market for flowable fill is limited by the high cost of the conventional fill materials. The current cost of the flowable fill product as produced by the ready-mixed concrete suppliers is in the range of $\$ 35-\$ 45 /$ cubic yard. The cost of the MDU flowable fill product must be lowered if this material is to penetrate the market. The formulations using MDU ash and lower-cost sand may offer that opportunity. An estimated market of 10,000 cubic yards of MDU flowable fill could be realized if prices could be made competitive.

\section{Laboratory-Scale MDU Flowable Fill Material Testing}


Although the results of the preliminary testing appeared promising, there were a number of technical issues relating to geotechnical and environmental performance that needed further clarification.

Geotechnical properties testing focused on: (1) a better definition of the pressures of expansion-shrinkage associated with wet-dry cycling; (2) a better definition of the settlement characteristics of the MDU flowable fill materials; (3) determination of the benefit of an air entraining agent (AEA) on freeze-thaw durability; and (4) assessment of longer-term embed materials with MDU flowable fill material. The laboratory testing results indicated that MDU flowable fill materials could be formulated to exhibit a range of properties. Expansion-shrinkage with wet-dry cycling proved not to be an issue. The settlement characteristics of the MDU structural-grade flowable fill material were excellent and the material behaved more like concrete than soil. The use of AEA was found not to be required for structural-grade applications, but may have benefit for reducing strength development and enhancing excavatability of excavatable-grade flowable fill material. A year-long test with a range of embed materials showed no evidence of corrosion. In summary, the geotechnical properties of the MDU flowable fill materials are excellent.

Environmental testing of the MDU flowable fill materials was based on discussions with the North Dakota Department of Health (NDDH). Environmental testing focused on additional standardized leaching tests, as well as specialized testing (Environmental Field Simulator) developed by WRI to assess the impact zone of MDU flowable fill materials on the adjacent soil environment. American Society for Testing and Materials (ASTM) D-3987 testing was conducted on both the MDU raw fly ash and MDU flowable fill products. The characterization of these materials was extensive, including trace metals and radionuclides. The list covered the relevant chemical species included in the Primary and Secondary Drinking Water Standards. In summary, with the exception of the $\mathrm{pH}$, the D-3987 extract meets the specifications of both the domestic and agriculture water standards.

WRI Environmental Field Simulator (EFS) methodology employed the use of fexiblewall permeameters to generate a permeate to assess leachate characteristics and impact on adjacent soils. EFS tests were conducted at a range of water-to-fill ratios, representing a range of rainfall events and annual precipitation quantities. The results of the EFS testing clearly established that the zone of impact for the fill materials is less than two inches. In fact, it is believed that the zone of impact is in the range of one to two centimeters.

\section{$\underline{\text { Field-Scale Demonstrations }}$}


WRI conducted several field-scale demonstrations of both structural (S)-grade and excavatable (E)-grade MDU flowable fill. The placement characteristics, strength development properties, excavatability (E-grade fills), and embed compatibility were assessed and monitored.

Approximately 48 cubic yards of MDU S-grade flowable fill material was poured at the R. M. Heskett Station as a base for the existing rail car load out for the plant. The flowable fill material was batched and delivered by Atlas Ready Mix. Due to the logistics at the Atlas plant, the mixes used standard concrete sand instead of the alternate cheaper sand material. The flowable fill material was poured at a thickness of 1 foot, and it essentially self-leveled. A concrete slab was poured over part of the base; and the forming, including driving stakes, was easily accomplished. The flowable fill was designed to reach over 1,000 psi. The cured flowable fill experienced front-end loader service over the winter and monitoring over the next year showed no deterioration of the material.

Three different E-grade MDU flowable fill mixes were tested (60E, 30E, 10E200). Approximately 8 cubic yards of the first two of the three mixes were poured into a trench to simulate trench-filling applications. These mixes were designed to produce strength of $<200 \mathrm{psi}$. As mentioned, the Atlas Ready Mix standard concrete sand was used instead of the finer alternate sand utilized in the laboratory tests. Typical embed materials, such as cast iron pipe, flanges, brass valves, and gas pipe were embedded in the fill materials. The third trench-filling demonstration used approximately 16 cubic yards of a low-strength flowable fill material. This material was designed to have a strength of $>50$ psi. This material was also designed to be excavated with hand tools, such as shovels. All of these flowable fill materials could support a person's weight after setting overnight. The excavatability of the 30E- and 60E-grade flowable fill products was evaluated in the spring. The strength development of the $60 \mathrm{E}$ mix was in excess of the target and could be considered a structural grade. The $30 \mathrm{E}$ was excavatable using a backhoe, but could not be excavated with hand tools. The 10E200 could be excavated using a shovel. The 10E200-grade fill was most applicable for utility trench-filling applications.

In summary, the results of the initial testing and demonstration activities proved the following:

- The market assessment indicated that a market exists in the Bismarck-Mandan area for structural construction applications, such as sub-bases for residential and commercial businesses, and excavatable fill applications, such as gas line and utility trench filling.

- The cost of the MDU flowable fill product must be lower than the current \$35-\$45/cubic yard price if it is to become a common construction material. Formulations using MDU ash and lower-cost sand alternatives offer that opportunity. An estimated market of 10,000 cubic yards of MDU flowable fill products could be realized if prices could be made competitive. 
- $\quad$ The geotechnical properties of the MDU ash-based flowable fill can be modified to meet the needs of a range of applications from structural fill to excavatable applications, such as utility trench fill.

- Environmental assessments using standard testing indicate that the environmental properties of the fill materials are compatible with numerous construction applications and do not pose a threat to either adjacent groundwater or soils.

- $\quad$ WRI developed an Environmental Field Simulator (EFS) method for assessing the impact of flowable fill materials on adjacent soils and found that the zone of impact is less than a couple of inches, thereby posing no threat to adjacent soils.

- Field-scale demonstrations of the MDU flowable fill were constructed and were successful for structural, as well as excavatable applications. Monitoring has demonstrated the geotechnical performance, environmental performance, and compatibility with common embed materials of the MDU flowable fill products.

The MDU flowable fill material appears to be a viable engineering material and environmentally safe. The results of the initial project sponsored by the U.S. DOE-NETL, MDU, and NDIC were so encouraging that MDU and WRI are pursuing the commercialization of the technology under the trademark, "Ready-FillTM." However, that initial study indicated that there still remained a number of technical and economic issues that needed to be determined and documented prior to putting the MDU controlled density fill (CDF) (Ready-FillTM) in commercial service with warrantees. These issues included: (1) the ability to produce a consistent product; (2) the ability to provide a product year round (cold weather retards strength development); and (3) the ability to evaluate and produce commercial quantities of MDU flowable fill using inexpensive materials.

\section{Product Variability and Product Service Environment Testing}

Testing examined the effect of MDU Heskett ash variability on the geotechnical properties of the resultant flowable fill. In addition, the effect of temperature conditions on the geotechnical properties was also examined. The flowable fill geotechnical properties were shown to vary with sand characteristics, ash characteristics, and even cement sources. However, a consistent product can be produced and supplied to a contractor.

Temperature affects the strength development of the curing flowable fill product. Cold curing conditions result in retarded set development and unconfined compressive strength. However, the flowable fill mixtures containing the MDU fly ash will generate heat during early hydration and curing, resulting in moderated temperatures of pours of sufficient size to avoid rapid heat loss in the field. The use of hot water in the winter and its heat generation will allow 
for its use during cold winter months, although some delay in strength development will occur. The limitations on the placement of the flowable fill product under cold conditions will be similar to that of other concrete products.

\section{Construction and Operation of Ready-Fill Plant}

A commercial-scale batch plant was constructed at a site centrally located between two of the ready-mix concrete suppliers in Bismarck, North Dakota. The Ready-Fill batch plant in Bismarck consists of a sand hopper with the capability of weighing the truck-load quantities of the fine sand, a sand belt conveyor to the truck load out, a fly ash hopper modified with a fabric filter, a fly ash auger to transfer ash to a weigh hopper, and a fly ash auger to transfer the weighed ash from the ash weigh hopper to the truck.

The ash is transported from the Heskett plant by cement tanker and pneumatically delivered into the ash hopper. The sand is delivered to the site by truck and stockpiled on site. Delivery of the sand to the sand hopper is accomplished with a front-end loader. The batch plant was capable of producing truck-load quantities of Ready-Fill for the demonstration activities.

\section{Demonstration and Monitoring of Commercial-Scale Application of Ready-Fill}

Seven commercial-scale demonstrations were conducted using a Ready-Fill product composed of waste sand, MDU fly ash, and cement and water. The Ready-Fill product was batched at the Ready-Fill plant in Bismarck and delivered by either Dakota Ready-Mix or Atlas Ready Mix to the demonstration sites. These demonstrations centered on three general applications for Ready-Fill, specifically excavatable, structural, and niche applications.

\section{- $\quad$ Ready-Fill Excavatable Applications}

Demonstration at the Ready-Fill Batch Plant

Utility Trench Backfill for Residential Subdivision Development

Fill Material for the Main Street Repair Project for the City of Bismarck

\section{- $\quad$ Ready-Fill Structural Applications}

Base Material for Coal Rail Car Unloading Facility at Heskett Station

Storm Water Drainage Ditch Construction at Krider Equipment

\section{- $\quad$ Ready-Fill Niche Applications}

Repair of MDU Sweet Avenue Substation Retaining Wall Erosion

Base Material for Residential Brick Patio Construction

The demonstrations were a success and the Ready-Fill product performed well from both a geotechnical and environmental perspective. The wide range of applications for the Ready-Fill product and its performance verifies that the Ready-Fill flowable fill product using waste ash and sand is truly a versatile construction material. 
In summary, the results of this phase of the testing and demonstration activities proved the following:

- $\quad$ Ready-Fill can be produced in commercial-scale facilities using low-cost materials (sand and ash) that have geotechnical and environmental properties that meet industry needs.

- $\quad$ The geotechnical properties of the ash-based flowable fill (Ready-Fill) can be modified to meet the needs of a range of applications from structural fill applications to excavatable applications, such as utility trench fill.

- The environmental properties of the fill materials are compatible with numerous construction applications and do not pose a threat to either adjacent groundwater or soils.

- $\quad$ The demonstrations at a commercial scale of Ready-Fill were successful for excavatable, structural, as well as niche applications.

The Ready-Fill product appears to be a commercially viable option for the use of MDU ash in the Bismarck and Mandan area. As a result of this project, new markets are commercially available for the ashes from the burning of lignite in fluidized-bed combustors. The state of North Dakota has benefited by establishing a commercial product for lignite-derived ash in flowable fill applications, thereby transforming a present waste product into a salable commodity in the construction industry and providing employment and economic growth. 


\section{INTRODUCTION}

Montana Dakota Utilities (MDU) is a generator of power for a major part of the northern Rocky Mountain area, and as such ashes generated from MDU facilities must be disposed or used in beneficial applications. Ash from MDU's R. M. Heskett Station in Mandan, North Dakota, represents one such ash management challenge. One potential use of the ash from this fluidized-bed combustor (FBC) is in the formulation of a flowable fill for a variety of construction applications in the Bismarck, North Dakota area.

Flowable fill material is a construction material that has gained acceptance for a number of construction applications. The performance characteristics can be modified for the specific application. Flowable fill material allows for reduced excavation costs and the performance characteristics can be modified for the specific construction application. Flowable fill material has been shown to be competitive with other construction methods. The applications for flowable fill material have been documented in the literature and flowable fill material is considered a commercial product in most regions of the country. Applications such as removable backfills, structural fills, isolation fills, and trench bedding have been demonstrated.

Recent mix designs for flowable fill materials have focused on the use of alternate materials such as fly ash and waste aggregate materials in an effort to reduce costs. Typical flowable fill mixtures consist of water, Portland cement, Class F or C fly ash, and fine aggregate. Ash from MDU's Heskett Station in Mandan, North Dakota, represents one such alternative material. The potential use of the ash from this FBC in the formulation of a flowable fill for a variety of construction applications in the Bismarck, North Dakota area was an option worth pursuing by MDU.

Western Research Institute (WRI), with sponsorship from MDU, performed a preliminary evaluation of the potential of using FBC ash from the MDU R. M. Heskett Station and a local fine aggregate in the formulation of flowable fill material for a number of construction applications. The results of the testing were encouraging and it appeared that both structural (S)and excavatable (E)-grade flowable fill can be formulated that use between 6.2 and $2.6 \%$ Type I/II Portland cement and 10 to $14 \%$ FBC fly ash, with the remainder being local sand aggregate and water. The geotechnical testing also indicated that MDU ash-based flowable fill material is stable and of sufficient strength for a wide range of applications. The leachate from the MDU FBC fly ash-based flowable fill material meets the regulatory limits for metals as specified by RCRA (Resource Conservation and Recovery Act), thereby resulting in a non-hazardous classification for both the raw fly ash as well as the MDU flowable fill material. The MDU flowable fill material does not appear to be detrimental to embed materials, such as copper, rebar, and Portland cement. However, galvanized conduit exposed to the MDU flowable fill material did result in a slight, white, corrosion scale. It is not clear, based on these relatively short-term tests, whether this represents a significant problem. 
The results of the preliminary testing culminated in the decision to pursue the concept further, including marketing, additional laboratory testing, and field demonstrations in construction activities in the Bismarck-Mandan area and the monitoring of these demonstrations for engineering and environmental performance. There were identified a number of technical and economic issues that needed to be determined and documented prior to putting the MDU controlled density fill (CDF) in commercial service with warrantees. The following were needed for commercial implementation: (1) the ability to produce a consistent product; (2) the ability to provide a product year round (cold weather retards strength development); and (3) the ability to evaluate and produce commercial quantities of MDU CDF using varied and inexpensive materials. The results of this program have been so encouraging that MDU is pursuing the commercialization of the technology under the trademark name of Ready-Fill ${ }^{\mathrm{TM}}$.

WRI, in conjunction with MDU and the U.S. DOE-NETL, conducted a follow-up twoyear program to examine the issues that are critical to the commercialization of the MDU CDF in the Bismarck-Mandan area. The program was funded by MDU, NDIC, and the WRI-U.S. DOE JSR Program. The following tasks were conducted:

\section{Task I. Product Variability and Product Service Environment Testing}

The MDU flowable fill materials produced under the laboratory-controlled conditions in the initial study did not have the same performance as the MDU flowable fill material made at a batch plant for the demonstrations. The success of the MDU flowable fill material is clearly contingent upon the delivery of a consistent product that can be used year round in a range of weather conditions. Testing examined the effect of MDU ash variability on the geotechnical properties of the resultant MDU flowable fill material. In addition, the effect of curing conditions, such as temperature, on the geotechnical properties was examined.

\section{$\underline{\text { Task II. Construction and Operation of CDF Plant }}$}

A CDF batch plant was constructed to examine the economics and technical performance of the Ready-Fill commercial product formulated with alternative materials. Commercial readymix concrete plants in the Bismarck-Mandan area were not able to modify their facilities to produce sufficient quantities for these tests. A portable batch plant was constructed with the capability of using alternate materials and producing quantities sufficient for assessing its characteristics in commercial-scale applications.

\section{Task III. Demonstration and Monitoring of Commercial-Scale Application of MDU CDF}

This task placed and monitored the performance of the Ready-Fill materials. 
This final report covers the results of the additional laboratory-testing program that addressed the geotechnical properties and environmental properties of the MDU flowable fills, as well as the results of the laboratory-scale product variability testing program, the construction of a commercial-scale production facility, and the results of commercial-scale demonstrations.

\section{BACKGROUND OF FLOWABLE FILLS}

\section{Flowable Fills and Applications}

Conventional flowable fill mixtures consist of water, Portland cement, Class F or C fly ash, and fine aggregate. Flowable fill is a construction material that has a specified compressive strength ranging from 80 to $1,200 \mathrm{psi}$ at 28 days, depending on the application. The characteristics of the flowable fill material also include a high slump of 9-10 inches and can be readied for use in 2 to 6 hours. This material is not concrete and is in a flowable state at the time of placement. The flowable fill material is usually mixed in a ready-mix concrete truck, keeping the material mixing during transport to prevent segregation of the aggregate. The material can be discharged by chutes or pumped using standard concrete or grout equipment.

A number of applications for flowable fill material have been documented in the literature (see References). Conventional flowable fill material is considered a commercial product in most regions of the country. A major consideration in the use of flowable fill material is the relative economics with other construction materials and methods. Flowable fill material has been shown to be competitive with these other construction methods. These applications include:

- $\quad$ Removable backfills

- $\quad$ Structural fills

- Isolation fills

- $\quad$ Trench bedding

- $\quad$ Road base
- $\quad$ Floor base

- $\quad$ Void fills

- Caisson and pile fills

- Small bridge restorations 
Table 1. Typical Mix Proportions and Characteristics of Flowable Fill Materials

\begin{tabular}{|c|c|c|c|c|c|}
\hline $\begin{array}{l}\text { Construction } \\
\text { Application }\end{array}$ & Cement $^{1}$ & $\begin{array}{c}\text { Type F } \\
\text { Fly Ash }^{1}\end{array}$ & $\begin{array}{c}\text { Fine Sand } \\
\text { Aggregate }^{1}\end{array}$ & Water $^{1}$ & $\begin{array}{c}28 \text { day UCS } \\
\text { (psi) }\end{array}$ \\
\hline Backfill & 50 & $250-300$ & $2,7,700-2,800$ & $\begin{array}{l}400-500 \\
\end{array}$ & 80 \\
\hline Structural & 200 & $250-300$ & 2,800 & 380 & 1000 \\
\hline Floor & 100 & $250-300$ & 3,100 & 300 & 500 \\
\hline $\begin{array}{l}\text { Backfill } \\
\text { (No Fly Ash) }\end{array}$ & 100 & $9 \mathrm{oz} \mathrm{AEA}^{2}$ & $2,800-2,900$ & 500 & 80 \\
\hline
\end{tabular}

UCS - unconfined compressive strength

${ }^{1} \mathrm{lb} / \mathrm{cu} . \mathrm{yd}$

${ }^{2}$ oz/cu. yd

\section{$\underline{\text { Backfills }}$}

Granular or site-excavated backfills may not achieve the uniformity of flowable fill materials, even if compacted properly in the required thickness layers. Flowable fill material has been used as a backfill around structures, buried tanks, and various conduit materials such as concrete, metal, fiberglass, reinforced plastic, and vitrified clay. The compressive strength of flowable fill backfill is usually 80 psi or less.

\section{$\underline{\text { Structural Fill }}$}

Flowable fill materials may be used for foundation support, in that it helps to distribute a structure's load over weak soil. In the case of uneven soil surfaces the flowable fill materials provide a uniform surface for the foundation structure. Structural fill mixtures typically have compressive strengths in the range of 200 to 1,000 psi.

\section{$\underline{\text { Isolation Fills }}$}

Flowable fill mixtures may provide good density and strength characteristics that may reduce the transfer of vibration and shock.

\section{$\underline{\text { Road Base }}$}

Flowable fill mixtures have been used for pavement bases and sub-bases in subdivisions, arterial streets, and parking lots. The mixtures can be placed directly from the mixer onto the subgrade between curbs. According to AASHTO (American Association of State Highway and Transportation Officials), the structural coefficients for this type of material are in the range of 
0.25 and 0.35 depending on the compressive strength that is achieved in the field. Flowable fill materials must have a wearing surface applied because they typically have poor wear resistance.

\section{Trench Bedding}

Flowable fill mixtures can be placed around and under conduit as trench bedding to provide uniform support and uniform density. Strengths are maintained low in order to facilitate excavation, if needed.

\section{$\underline{\text { Void Filling }}$}

Cavities under slabs, pavement, and structures have been filled with flowable fill materials. For these applications erosion conditions should be considered. Abandoned mines, old sewers, and underground tanks have been filled with flowable fill materials.

Non-standard materials in the formulation of flowable fill have been used and their selection is typically based on the flowability, strength, removability, and density characteristics of the resultant mix.

Recent mix designs for flowable fill material have focused on the use of alternate materials such as fly ash and waste aggregate materials in an effort to reduce costs. Ash from the MDU Heskett Station in Mandan, North Dakota, represents one such alternative material. The potential use of the ash from this FBC in the formulation of a flowable fill for a variety of construction applications in the Bismarck-Mandan area was a beneficial ash use option deemed worth investigating by MDU.

\section{RESULTS OF PRELIMINARY TESTING PROGRAM}

WRI, with sponsorship from MDU, performed a preliminary evaluation of the potential of using FBC ash from the MDU R. M. Heskett Station and a local fine aggregate in the formulation of flowable fill materials for a number of construction applications. The results of the testing were encouraging and it appeared that both S- and E-grade flowable fill material can be formulated that are stable and of sufficient strength for a wide range of applications.

Although the intent of the preliminary testing was to evaluate the engineering aspects of the MDU flowable fill, a limited assessment of the environmental character of the ash and the resultant flowable fill was conducted. The purpose of this testing was to confirm that the leachate from the MDU FBC fly ash-based flowable fill material meets the regulatory limits for metals as specified by RCRA (CFR 241), thereby resulting in a non-hazardous classification for the MDU flowable fill materials. The results are presented in Table 3. Indeed, the leachate from the MDU FBC fly ash-based flowable fill materials met the regulatory limits for metals required for a non-hazardous classification under RCRA for both the raw fly ash, as well as the MDU 
flowable fill material. In fact, the TCLP (Toxicity Characteristic Leaching Procedure) leachate met the Drinking Water Standards for many of these metals.

Clearly, this preliminary environmental testing did not delineate all of the environmental issues that must be addressed prior to acceptance by the engineering community and prior to approval by the NDDH. Additional testing, as well as demonstration and monitoring of the material in full-scale applications was needed based on the results of the preliminary testing. WRI and MDU proposed such a program that addressed both the geotechnical and environmental concerns required for commercial-scale applications.

In order for MDU FBC fly ash-based flowable fill material to be a viable material for construction applications, MDU recommended that it must meet a number of targeted performance specifications, including: (1) flowable (8-inch flow); (2) achieve initial set of at least 27 psi within 4 hours; (3) possess strengths less than 150 psi to allow for re-excavation; (4) have non-shrink or settlement characteristics; (5) exhibit benign environmental leachate characteristics; and (6) be compatible with embedded materials, such as pipe and conduit. The results of the testing were encouraging and it did appear feasible to produce a flowable fill material that meets the geotechnical and environmental specifications set forth above. Specifically, the testing has concluded the following:

- $\quad$ Both S- and E-grade flowable fill material can be fabricated that use between 6.2 and $2.6 \%$ Type I/II Portland cement and 10 to $14 \%$ FBC fly ash, with the remainder being fine sand aggregate and water. The use of sulfate resistant cements (e.g., Type III and Type V) does not appear to be warranted.

- $\quad$ The MDU FBC fly ash-based flowable fill material meets the geotechnical specifications commonly found for conventional flowable fill material, including flows of 8 inches or more, set times for achieving 27 psi in the range of 4 to 5 hours, ultimate strengths of less than 150 psi for excavatable flowable fill material and greater than 200 psi for structuralgrade flowable fill material (see Table 2). Expansion characteristics of the MDU flowable fill material appear to indicate a dimensionally stable material. However, under wet-dry cycling, there was an observed expansion-shrinkage cycling on the order of $0.05 \%$ that matched the wet and dry cycling. It is unclear if sufficient pressures are present to create stresses to the embedded materials.

- $\quad$ The use of FBC fly ash did retard the strength development, thereby requiring the addition of commercially available accelerators. Calcium chloride-based accelerators appear to be best suited for these applications.

- $\quad$ The desire to improve freeze/thaw durability for North Dakota applications necessitated the need for low dosages of a commercially available AEA. Darafill, manufactured by 
WR Grace Construction Products, appears to be an effective AEA for these flowable fill materials.

Table 2. Summary of Performance of Structural- and Excavatable-Grade Flowable Fill Material

\begin{tabular}{|l|c|c|} 
& $\begin{array}{c}\text { MDU } \\
\text { Excavatable-Grade } \\
\text { Flowable Fill }\end{array}$ & $\begin{array}{c}\text { MDU } \\
\text { Structural-Grade } \\
\text { Flowable Fill }\end{array}$ \\
\hline Mix Proportions & & \\
MDU FBC Fly Ash (lb/cu. yd) & 353 & 356 \\
Portland Cement (lb/cu. yd) & 63 & 150 \\
Aggregate Wash Fines (lb/cu. yd) & 2,116 & 2,135 \\
Water (gal/cu. yd) & 67.7 gal \\
Darafill (oz/cu. yd) & 2 oz & 75.0 gal \\
Chloride Accelerator (\%) & $1 \%$ & 2 oz \\
Mix Properties & 2,997 & $1 \%$ \\
Yield (lb/cu. yd) & $8-i n c h$ minimum & 8 -inch minimum \\
Flow (inch) & $4-5$ hrs & $4-5$ hrs \\
Time to Traffic (hr) & $70 \mathrm{psi}$ & $>200 \mathrm{psi}$ \\
UCS @ 28 days (psi) & $0.004-0.113 \%$ & $0.004-0.113 \%$ \\
Expansion - Sealed and W/D Cycles (\%) & & \\
\hline
\end{tabular}

- $\quad$ The MDU flowable fill material does not appear to be detrimental to embed materials such as copper, rebar, and Portland cement. However, galvanized conduit exposed to the MDU flowable fill material did result in a slight, white, corrosion scale. It is not clear, based on the results of the testing, if this represents a significant problem.

- $\quad$ The leachate from the MDU FBC fly ash-based flowable fill materials meets the regulatory limits for metals as specified by RCRA, thereby resulting in a non-hazardous classification for both the raw fly ash as well as the MDU flowable fill material. In fact, the TCLP leachate meets many of the Drinking Water Standards.

Table 3. TCLP Leachate Composition of the MDU Fly Ash and MDU and Conventional 


\section{Flowable Fill Materials}

\begin{tabular}{|l|c|c|c|c|c|}
\hline & $\begin{array}{c}\text { RCRA } \\
\text { Limits }\end{array}$ & $\begin{array}{c}\text { MDU Fly } \\
\text { Ash - A }\end{array}$ & $\begin{array}{c}\text { MDU Fly } \\
\text { Ash - B }\end{array}$ & $\begin{array}{c}\text { MDU } \\
\text { Flowable Fill }\end{array}$ & $\begin{array}{c}\text { MDU } \\
\text { Flowable Fill }\end{array}$ \\
\hline Grade & & & & $\boldsymbol{S}$ & $\boldsymbol{E}$ \\
\hline Arsenic, ppm & 5.0 & $<0.10$ & $<0.5$ & 0.006 & 0.016 \\
Barium, ppm & 100.0 & 0.768 & $<10$ & 0.753 & 0.444 \\
Cadmium, ppm & 1.0 & $<0.010$ & $<0.1$ & $<0.010$ & $<0.010$ \\
Chromium, ppm & 5.0 & $<0.008$ & $<0.5$ & 0.021 & $<0.008$ \\
Lead, ppm & 5.0 & $<0.200$ & $<0.5$ & $<0.100$ & $<0.100$ \\
Mercury, ppm & 0.02 & $<0.002$ & $<0.02$ & $<0.002$ & $<0.002$ \\
Selenium, ppm & 1.0 & $<0.100$ & $<0.2$ & $<0.200$ & $<0.200$ \\
Silver, ppm & 5.0 & $<0.010$ & $<0.5$ & $<0.010$ & $<0.010$ \\
pH & $<12.5$ & 11.8 & nd & 11.0 & 9.9 \\
Chlorides, ppm & na & nd & nd & 231 & 258 \\
Sulfates, ppm & na & nd & nd & 394 & 586 \\
\hline
\end{tabular}

$\mathrm{S}$ - structural E - excavatable

The preliminary testing did not clearly resolve all of the technical issues that must be addressed prior to acceptance by the engineering community or prior to approval by the NDDH. Technical issues such as environmental impact on soils, long-term performance, and long-term impact on embed materials still existed. Additional tests addressing these issues, as well as the demonstration and monitoring of the material in full-scale applications were needed before commercialization of this material could be realized.

\section{RESULTS OF FIRST TESTING PROGRAM}

Based on the results of the preliminary testing, WRI and MDU conducted a program of marketing, testing, and demonstration of the MDU ash-based flowable fill material. The program was funded by MDU, NDIC, and the WRI-U.S. DOE Jointly Sponsored Research Program.

The objectives of the project were to: (1) assess the market for flowable fill in the Bismarck-Mandan area; (2) evaluate the geotechnical properties and environmental compatability of the MDU flowable fill products; and (3) construct and monitor demonstrations of the various grades of MDU flowable fill material in field-scale demonstrations. The project was to determine through laboratory and field demonstration testing the technical and environmental potential of using FBC ash from the MDU Heskett FBC plant in the production of E- and S-grade flowable fill materials for construction applications.

The marketing and demonstration program conducted herein incorporates the following contract tasks. 
- $\quad$ Task I. MDU Flowable Fill Material Market Assessment

- $\quad$ Task II. MDU Flowable Fill Material Additional Laboratory Testing

- $\quad$ Task III. Demonstration of MDU Flowable Fill Material in North Dakota

- $\quad$ Task IV. Monitoring of Flowable Fill Material Demonstrations

- $\quad$ Task V. Reporting

Following is a brief description of each of these tasks. The program was constructed to address the following activities in the form of Phases and associated Tasks.

Phase I addressed the assessment of the market potential for the MDU flowable fill material in the Bismarck-Mandan area of North Dakota and incorporates Task 1. Task 1 (MDU Flowable Fill Market Assessment) was designed to convince both the engineering community and the NDDH of the benefits and inherent environmental safety of the MDU ash-based flowable fill material. MDU and WRI personnel were to engage in workshops, meetings, and discussions with the city Engineering Departments, contractors, and discussions with the NDDH. The objectives of these activities were to: (1) inform these parties about the engineering and environmental properties of the MDU flowable fill material; (2) ascertain their concerns so that they could be addressed through further testing; and (3) ultimately receive their endorsement or permission to pursue full-scale demonstrations of the MDU flowable fill material.

Phase II addressed the additional laboratory testing that was required to assess the geotechnical properties as well as the environmental and embed compatibility issues and incorporates Task 2. Task 2 (MDU Flowable Fill Material Additional Laboratory Testing) was designed to elaborate on the results of the preliminary testing that appeared promising, but still needed clarification on a number of issues, including: (1) better definition of the pressures of expansion-shrinkage associated with wet-dry cycling; (2) better definition of the settlement characteristics of the flowable fill material; (3) determination of the benefit of AEAs on freeze/thaw durability; and (4) assessment of longer-term embed materials compatibility (particularly with galvanized conduit) with MDU flowable fill material. These items were to be addressed prior to any commercial application of the MDU flowable fill material.

In addition, discussions with the NDDH relative to the preliminary testing results suggested that additional environmental testing be conducted prior to deployment of the technology to field-scale demonstrations or commercial applications. Additional information was needed, including;

- More complete compositional information 
- $\quad$ Results of an alternative extraction procedure (i.e., ASTM D-3987)

- $\quad$ Analysis for radionuclides

- $\quad$ Potential effect on plants and soils.

These requests were incorporated into the laboratory-scale testing conducted as part of this program.

Phase III addressed the field demonstration of the MDU flowable fill materials and the associated monitoring of those demonstrations and incorporates Tasks 3 and 4 . Task 3 (Demonstration of MDU Flowable Fill Material in North Dakota) involved discussions with MDU personnel and indicated that they believed there were a number of demonstration opportunities in the Bismarck-Mandan area for the flowable fill material. MDU and WRI were to pursue these opportunities and a demonstration of the application of MDU flowable fill was to be conducted in the Bismarck-Mandan area during the summer of 1997. Two demonstrations were proposed addressing the structural-grade flowable fill material as well as the excavatable (trench filling) flowable fill applications. These demonstrations were to verify the potential of the MDU flowable fill product using full-scale equipment. The size of the demonstrations would be sufficient to allow the assessment of the economic benefits of flowable fills to be ascertained, as well as the environmental characteristics and the technical performance of the MDU flowable fill material.

Task 4 (Monitoring of MDU Flowable Fill Demonstration) was designed to provide technical monitoring support for the demonstration activities. This support was in the form of geotechnical and environmental monitoring. The geotechnical properties, such as strength, flow, set characteristics, and dimensional stability were to be monitored for each demonstration. Environmental leachate analyses were to be conducted on both of the flowable fill materials used in the demonstrations.

The results of the testing program are presented according to the three Phases described above and the associated Tasks.

\section{$\underline{\text { Results of Phase I - Market Assessment (Task 1) }}$}

The MDU flowable fill material appears to be a viable engineering material capable of effecting cost savings for a number of construction applications. Testing has also shown the material to be non-hazardous according to U.S. EPA (Environmental Protection Agency) TCLP 
testing. Market assessments and marketing of the MDU flowable fill material are integral to convincing both the engineering community and the NDDH of the benefits and inherent environmental safety of the MDU flowable fill material in construction applications in North Dakota.

As part of the market assessment, MDU and WRI personnel participated in workshops, meetings, and discussions with various engineering departments, contractors, and the NDDH. The objectives of these activities were to: (1) inform these parties about the engineering and environmental properties of the MDU flowable fill material; (2) ascertain their concerns so that they could be addressed through further testing; and (3) ultimately receive their permission to pursue a demonstration of the MDU flowable fill material.

A market assessment of the Bismarck-Mandan region for the MDU flowable fill material was conducted by MDU. The market assessment addressed the acceptability of the MDU flowable fill by contacting a number of potential consumers, such as the city of Bismarck, local contractors, MDU gas resources personnel, and the ready-mix concrete suppliers to solicit their evaluation of the flowable market. These groups were invited to review the performance data as well as observe the construction of the demonstrations conducted in the fall and winter of 1998. The applications suggested for the flowable material ranged from structural applications, such as sub-bases for residential and commercial businesses, to excavatable fill applications, such as gas line and utility trench filling.

The current market for the conventional flowable fill is limited by the high cost of the conventional flowable fill materials compared to alternative fill materials. The current cost of the product as produced by the ready-mix concrete suppliers is in the range of $\$ 35-\$ 45 /$ cubic yard. The cost of the MDU flowable must be lowered if this material is to become a common construction material in the area. The formulations using MDU ash and lower-cost sand alternatives offer that opportunity. An estimated market of 10,000 cubic yards of MDU flowable fill product could be realized if prices could be made competitive.

\section{$\underline{\text { Results of Phase II - Laboratory Geotechnical and Environmental Tests (Task 2) }}$}

MDU flowable fill material is a construction material that has a number of structural and excavatable applications, such as removable backfills, structural fills, isolation fills, and trench bedding. Excavatable grade is low strength $(<200 \mathrm{psi})$ that can be used for trench filling and other applications that may require excavation at a later time. Structural grade is custom formulated for the application, but typically has strengths between 750 and 1,500 psi. Structuralgrade MDU flowable fill material is used in applications that need the strength to support activities and structures built on it. MDU flowable fill material has advantages over other flowable fill and borrow fill materials in that it uses two waste materials and as such has a price advantage. Like all flowable fill materials, the excavation costs associated with MDU flowable 
fill material placement are reduced and MDU flowable fill material use does not require compaction to prevent later subsidence.

Although the results of the preliminary testing appeared to be promising, there were a number of technical issues identified that needed further clarification relating to geotechnical and environmental performance. The geotechnical properties that remained undefined included: (1) better definition of the pressures of expansion-shrinkage associated with wet-dry cycling; (2) better definition of the settlement characteristics of the MDU flowable fill material; and (3) determination of the benefit of AEA on freeze/thaw durability.

In addition, an assessment of the permeability and permeate quality of flowable fill material and its impact on soils was conducted. Longer-term embed materials compatibility (particularly with galvanized conduit) with MDU flowable fill material was also conducted.

\section{$\underline{\text { Source and Properties of the MDU Fly Ash }}$}

Sources of Test Materials. Three materials are used in the formulation of the MDU flowable fill material. These include the following:

- $\quad$ Fly Ash: Ash was supplied by Montana-Dakota Utilities from their Heskett FBC facility in Mandan, North Dakota. Approximately two barrels of the fly ash representative of their operation was delivered to WRI. The two barrels were homogenized and representative splits were produced for testing. Both the geotechnical and geochemical testing used representative splits of the ash.

- $\quad$ Sand: Two barrels of washed fines from the Fischer Sand and Gravel aggregate quarry in the Bismarck, North Dakota area were collected and sent to WRI for use in the flowable fill mix testing.

- Cement: Cement used in the testing was a Portland cement furnished by Mountain Cement in Laramie, Wyoming. The composition of the cement is a Type I/II, similar to that used in the Bismarck-Mandan area. The cement used for the field demonstrations was from the LaFarge Company in Bismarck, North Dakota. Both cements were Type I/II.

Bulk Chemistry of the MDU Fly Ash. The chemical composition of the MDU fly ash is presented in Table 4. The major and trace element values were determined by atomic absorption (AA) and graphite furnace AA. The MDU ash is similar to a number of ashes produced by the fluidized-bed combustion of low-sulfur coals. The high-alkali (sodium) content is indicative of the sodium found in the low-ranked lignite coals. The trace metal concentrations presented in Table 5 show the relatively low concentrations of most metals of environmental concern. 
For comparison, Table 5 summarizes the RCRA metals content in cement and soils. Table 5 also presents the data for the MDU fly ash. The data show that the metals concentrations in the MDU fly ash are similar to other construction materials and natural soils. The phase composition of the MDU fly ash was performed by X-ray diffraction (XRD). The results show the ash to be composed principally of quartz $\left(\mathrm{SiO}_{2}\right)$, sodium sulfate $\left(\mathrm{Na}_{2} \mathrm{SO}_{4}\right)$, calcium sulfate $\left(\mathrm{CaSO}_{4}\right)$, and dehydroxylated clays.

Table 4. Major and Trace Element Composition of the MDU Fly Ash

\begin{tabular}{|lc|lc|}
\hline Chemical Parameters & MDU & MDU \\
(wt \%, as-received basis) & Fly Ash & Trace Metals, ppm & Fly Ash \\
\hline Ash & 88.10 & Antimony & $<0.1$ \\
$\mathrm{LOI}$ & 11.90 & Arsenic & 21.65 \\
$\mathrm{SiO}_{2}$ & 26.94 & Berylium & 1.50 \\
$\mathrm{TiO}_{2}$ & 0.38 & Boron & 464 \\
$\mathrm{Al}_{2} \mathrm{O} 3$ & 8.02 & Cadmium & 0.33 \\
$\mathrm{Fe}_{2} \mathrm{O} 3$ & 4.49 & Chromium & 10.2 \\
$\mathrm{CaO}$ & 20.77 & Cobalt & 3.45 \\
$\mathrm{MgO}$ & 7.56 & Copper & 31.5 \\
$\mathrm{Na} 2 \mathrm{O}$ & 3.74 & Lead & 11.80 \\
$\mathrm{~K} 2 \mathrm{O}$ & 0.63 & Mercury & 0.6058 \\
$\mathrm{P} 2 \mathrm{O} 5$ & 1.60 & Molybdenum & 3.00 \\
$\mathrm{SO} 3$ & 10.48 & Nickel & 8.00 \\
$\mathrm{MnO}$ & 0.15 & Selenium & 1.78 \\
$\mathrm{BaO}$ & 0.57 & Silver & $<0.5$ \\
\hline SrO & 0.39 & Thallium & 0.20 \\
Total & 97.62 & Vanadium & 16.4 \\
Radioactivity (pCi/g) & & Zinc & 63.0 \\
$\mathrm{Uranium}$ & & & \\
Gross Alpha & 2.4 & & \\
$\mathrm{Radium} 226$ & $1.42+/-0.09$ & & \\
$\mathrm{Radium} \mathrm{228}$ & $0.380+/-0.02$ & & \\
$\mathrm{Comb}$ Ra226+228 & $0.195+/-0.04$ & & \\
\hline
\end{tabular}

Table 5. Metals Ranges for Common Fill and Construction Materials

\begin{tabular}{|l|c|c|c|}
\hline RCRA Metal (ppm) & $\frac{\text { Heskett Fly Ash }}{21.65}$ & $\frac{\text { Portland Cement }}{5-71}$ & $\frac{\text { Natural Soil }}{0.1-73}$ \\
Arsenic & 5,100 & $91-1402$ & $10-1,500$ \\
Barium & 0.33 & $0.03-1.12$ & $0.01-0.7$
\end{tabular}




\begin{tabular}{|l|c|c|c|} 
Chromium & 10.2 & $25-422$ & $5-1,000$ \\
Lead & 11.80 & $1-75$ & $2-200$ \\
Mercury & 0.6058 & $0.014-0.039$ & $0.01-3.4$ \\
Selenium & 1.78 & $0.62-2.23$ & $0.1-2$ \\
Silver & $<0.5$ & $6.75-19.90$ & na \\
\hline
\end{tabular}

na - not available

Reference: Portland Cement Association, Aubert (1977), Ferguson (1990), Hutchinson and Meema (1987), Korcak (1995), and Smith and Levenson (1980)

\section{Mix Design and Geotechnical Properties of MDU Flowable Fill Material}

Mix Design. Mix design testing resulted in the formulation of both excavatable-grade and structural-grade flowable fill materials. The results of the mix design tests are summarized in Table 6. The mix design was based principally on the strength properties as presented in Table 6.

Geotechnical Properties. There are a number of geotechnical properties that the MDU flowable fill product needs to meet for the different applications. For both excavatable and structural grades of flowable fill, the flow, set times, strength development, and embed compatibility are key properties of the MDU flowable fill product. For structural-grade flowable fill, essential geotechnical properties include flow, set times, strength development, settlement, freeze-thaw durability characteristics, and embed compatibility.

Flow. The proper flow of the product mix is important to the ability of the product to effectively fill voids and encapsulate embed materials. A high flow value will result in effective filling characteristics but tends to reduce strength and extend set times. An 8-inch flow (according to the National Ready-Mixed Concrete Association procedure) was found to balance the filling characteristics and the strength/set time development needs for the flowable fill application. A photograph of the consistency and flow characteristics of the MDU flowable fill product is shown in Figure 1.

Table 6. Comparison of the Mix Proportions of the MDU Flowable Fill and Medium- and Low-Strength Concrete

\begin{tabular}{|l|cccc|cc|}
\hline \multirow{4}{*}{} & \multicolumn{3}{|c|}{ MDU } & \multicolumn{2}{c|}{$\begin{array}{c}\text { Portland Cement } \\
\text { Concrete }\end{array}$} \\
\cline { 2 - 7 } & E Grade & E Grade & E Grade & S Grade & Low & Medium \\
& $(10 E 200)$ & $(30 E)$ & $(60$ E) & (S) & Strength $^{1}$ & Strength $^{1}$ \\
\hline
\end{tabular}




\begin{tabular}{|c|c|c|c|c|c|c|}
\hline \multicolumn{7}{|l|}{ Mix Components } \\
\hline Portland Cement (pcy) & 10 & 30 & 60 & 60 & 430 & 600 \\
\hline Fine Aggregate (pcy) & 2,750 & 2,750 & 2,750 & 2,750 & 1,350 & 1,430 \\
\hline Coarse Aggregate (pcy) & & & & & 1,970 & 1,740 \\
\hline Water (pcy) & 550 & 560 & 565 & 570 & 300 & 300 \\
\hline \multicolumn{7}{|l|}{ Properties } \\
\hline Strength@28 days (psi) & $<80$ & 500 & $<200$ & $>1,000$ & 2,650 & 4,520 \\
\hline Unit Weight (pcf) & 120 & 122 & 123 & 125 & 130 & 135 \\
\hline
\end{tabular}

PC-Portland Cement

${ }^{1}$ Reference: Concrete, Structure, Properties and Materials (Mehta, 1986)

Set Times. Set time characteristics describe the stiffening and early strength development of the freshly placed flowable fill product. The set time was determined according to ASTM C-403. Set times for the S-grade flowable fill material were described in a similar format as concrete. E-grade flowable fill material will often not meet the 4,000-psi penetration resistance required for final set. Testing noted that the set times varied dramatically with the temperature of curing. The temperature affect on set time for typical E- and S-grade flowable fill material is shown in Table 7. Field activities have indicated that S-grade flowable fill material can support workers and light track traffic within 4 hours in the summer $\left(23-32{ }^{\circ} \mathrm{C}, 72-90{ }^{\circ} \mathrm{F}\right.$ curing) and within $16-24$ hours in the winter $\left(0-5{ }^{\circ} \mathrm{C}, 30-40{ }^{\circ} \mathrm{F}\right.$ curing).

Strength Development. The strength development of the Ready-Fill product is designed to vary from $<200$ psi for E grade to 750 to 1,500 psi for S grade. Above 200-psi strength, the Egrade Ready-Fill requires a backhoe or larger equipment to excavate. As such, 200 psi is the maximum design limit, while typical strengths at 90 days range from 75 to 150 psi. 


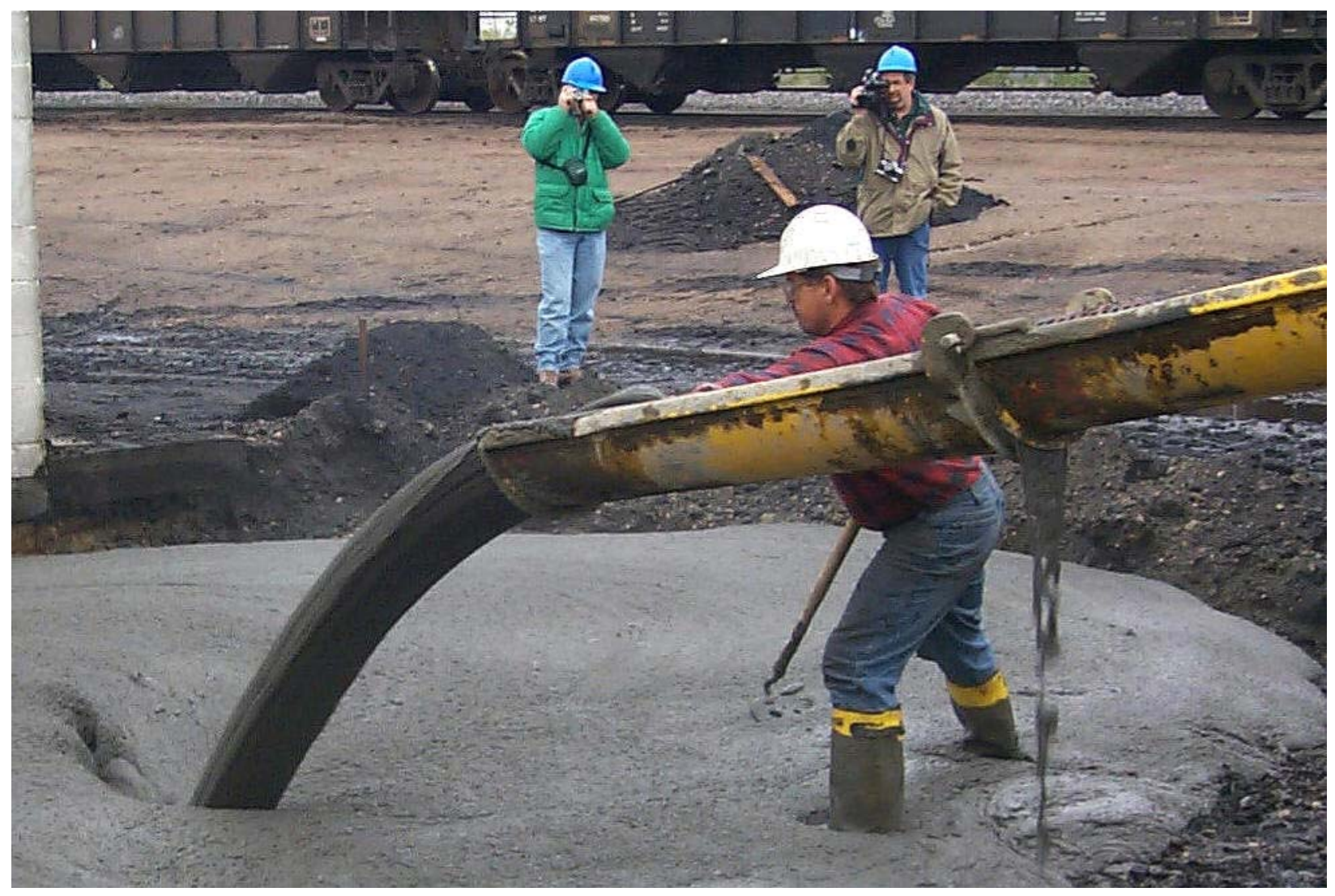

Figure 1. Photograph Showing the Flow Characteristics of MDU Flowable Fill Material

Table 7. Set Time Characteristics of Structural-Grade and Excavatable-Grade Flowable Fill Material Cured Under Cold and Warm Conditions

\begin{tabular}{|l|c|c|c|}
\hline Set Time Characteristics & S Grade & S Grade & E Grade \\
Penetration Resistance (psi) & A & B & A \\
\hline 24 hours $-\left(23^{\circ} \mathrm{C}, 73^{\circ} \mathrm{F}\right)$ & 1,209 & 176 & 44 \\
24 hours $-*\left(0-5^{\circ} \mathrm{C}, 30-40^{\circ} \mathrm{F}\right)$ & 64 & 14 & 20 \\
48 hours $-\left(23^{\circ} \mathrm{C}, 73^{\circ} \mathrm{F}\right)$ & $>6,400$ & 1,504 & 176 \\
48 hours $-*\left(0-5^{\circ} \mathrm{C}, 30-40^{\circ} \mathrm{F}\right)$ & 176 & 192 & 64 \\
\hline
\end{tabular}

* Field cured as part of demonstrations.

Higher strength development is needed for structural applications of the MDU flowable fill product. The application dictates the strength development required. For comparison, a typical low-strength Portland cement concrete exhibits strengths of 2,650 psi and a mediumstrength concrete exhibits strengths of 4,520 psi. The cement usage in these concretes is an order of magnitude higher than required for MDU flowable fill material and therefore is more costly. 
As with the set times, the strength development of MDU flowable fill material varies as a function of the temperature of curing, as shown in Table 8.

A comparison of the strength development of the MDU flowable fill material as a function of curing conditions of sealed and submerged curing is shown in Table 9. The data indicate that the MDU flowable fill can develop strength under a range of saturated curing conditions. For comparison, data are presented for a commercially available flowable fill material in the Bismarck, North Dakota area. The commercial flowable fill material is an E grade, while the data shown for the MDU flowable fill are for an S grade.

Table 8. Strength Development of Structural-Grade and Excavatable-Grade MDU Flowable Fill Material Cured Under Cold and Warm Conditions

\begin{tabular}{|c|c|c|c|}
\hline Unconfined Compressive & S Grade & S Grade & E Grade \\
Strength (psi) & A & B & A \\
\hline 28 days $-\left(23^{\circ} \mathrm{C}, 73^{\circ} \mathrm{F}\right)$ & 993 & 649 & 101 \\
28 days $-\left(5^{\circ} \mathrm{C}, 40^{\circ} \mathrm{F}\right)$ & 538 & 103 & 63 \\
180 days $-\left(23^{\circ} \mathrm{C}, 73^{\circ} \mathrm{F}\right)$ & 1,344 & 849 & 133 \\
\hline
\end{tabular}

Table 9. Strength Development of MDU and Conventional Flowable Fill

\begin{tabular}{|c|c|c|c|c|}
\hline Mix Proportions (pcy) & \multicolumn{2}{|c|}{$\begin{array}{l}\text { MDU S-Grade } \\
\text { Flowable Fill }\end{array}$} & \multicolumn{2}{|c|}{$\begin{array}{c}\text { Commercial E-Grade } \\
\text { Flowable Fill }\end{array}$} \\
\hline MDU FBC Fly Ash & \multirow{2}{*}{\multicolumn{2}{|c|}{300}} & \\
\hline Class C Fly Ash & & & & 292 \\
\hline Sand & \multicolumn{2}{|c|}{2,750} & \multicolumn{2}{|c|}{2,750} \\
\hline Cement & \multicolumn{2}{|c|}{300} & \multicolumn{2}{|c|}{30} \\
\hline Water & \multicolumn{2}{|r|}{560} & \multicolumn{2}{|c|}{459.9} \\
\hline Density (pcf) & \multicolumn{2}{|c|}{125.3} & \multicolumn{2}{|c|}{124.8} \\
\hline $\mathbf{U C S}$ & Seal Cured & Sealed & Sealed Cured & Sealed \\
\hline (psi) & $23^{\circ} \mathrm{C}$ & 14 days & $23^{\circ} \mathrm{C}$ & 14 days \\
\hline 7 days & 330 & Submerged $\left(23^{\circ} \mathrm{C}\right)$ & 63 & Submerged $\left(23^{\circ} \mathrm{C}\right)$ \\
\hline 21 days & & 489 & & 159 \\
\hline 28 days & 688 & & 168 & \\
\hline 42 days & \multirow{3}{*}{763} & 888 & \multirow{3}{*}{171} & 84 \\
\hline 90 days & & & & \\
\hline 104 days & & 689 & & 37 \\
\hline
\end{tabular}

UCS - unconfined compressive strength

Freeze-Thaw and Wet/Dry Cycle Durability. Freeze-thaw cycle durability is important for structural-grade applications in that these applications typically require the fill material not to 
degrade under freeze-thaw cycles. In concrete applications, freeze-thaw durability is enhanced with the addition of AEAs. The AEA creates small air bubbles that help resist cracking during freeze-thaw cycles. The potential benefits of AEA on the freeze-thaw cycle resistance of Sgrade Ready-Fill were quantified according to ASTM D-560 testing. Testing confirmed that commercially available AEAs are compatible with Ready-Fill materials, in that they do entrain air. The results of the testing are presented in Table 10. The results of the testing indicate that AEA addition is not needed for freeze-thaw cycle durability.

\section{Table 10. Effect of Air Entraining Agent (AEA) Addition to Structural-Grade MDU Flowable Fill on Freeze/Thaw Cycle Durability}

\begin{tabular}{|l|c|c|}
\hline Freeze-Thaw & S-Grade MDU Flowable Fill \\
Cycle Tests & $\begin{array}{c}\text { S-Grade MDU Flowable } \\
\text { Fill Product with AEA }\end{array}$ \\
\hline & $2.43 \%$ & $0.87 \%$ \\
Loss after 12 Cycles & $-0.01 \%$ & $-0.01 \%$ \\
\hline Volume Change after 12 Cycles & & without AEA
\end{tabular}

Testing also addressed the effect of wet/dry cycling on the durability of the MDU flowable fill. The wet/dry testing followed the ASTM D-559 procedures. The results of the testing under wet/dry cycling are presented in Table 11.

Table 11. Summary of the Results of the Wet/Dry Testing

\begin{tabular}{|l|c|c|}
\hline Wet/Dry Cycle Tests & $\begin{array}{c}\text { MDU Flowable Fill } \\
\text { No AEA Addition }\end{array}$ & $\begin{array}{c}\text { MDU Flowable Fill } \\
\text { Made with AEA }\end{array}$ \\
\hline \% Loss after 12 cycles & $9.19 \%$ & $17.30 \%$ \\
$\%$ Volume Change after 12 Cycles & $-1.85 \%$ & $-1.74 \%$ \\
\hline
\end{tabular}

Wet/dry durability of the MDU flowable fill appears to meet the requirements of a stabilized soil $(<18 \%$ weight loss after 12 cycles).

Expansion-Shrinkage Pressures. Wet/dry cycle durability testing by WRI of the MDU flowable fill material indicated that there was an expansion-shrinkage cycling of the material coincident with the wet/dry cycles (Table 12). Although small in magnitude, this swelling and contraction of the material on wet/dry cycling could be detrimental to embed materials. However, the testing was conducted under zero load pressures. It is unclear whether under loads equivalent of several feet of fill material if the expansion/shrinkage would still exist. As a result, testing was conducted to determine the pressures exerted by the MDU flowable fill material during wet/dry cycles. ASTM D-2435 and 3877 were modified to determine these values. In these tests, the load is changed to present a non-expanding situation. The pressure associated with this load represents the amount of load (depth of fill) necessary to stop the 
expansion/shrinkage. Results indicate that wet/dry cycle expansion will not occur with soil cover of about 1.5 feet.

Table 12. Free Linear Expansion Characteristics of MDU Structural-Grade Flowable Fill Cured Under Sealed and Wet/Dry Cycles at $23^{\circ} \mathrm{C}$

\begin{tabular}{|l|c|c|}
\hline MDU S Grade & Seal Cured & W/D Cycles \\
Curing Temperature & $\mathbf{2 3}{ }^{\circ} \mathbf{C}$ & $\mathbf{2 3}{ }^{\circ} \mathbf{C}$ \\
\hline 14 day & 0.000 & -0.004 \\
17 day & -0.013 & -0.086 \\
19 day & -0.013 & -0.034 \\
21 day & -0.013 & -0.082 \\
24 day & 0.000 & -0.026 \\
26 day & -0.009 & -0.056 \\
28 day & -0.009 & -0.056 \\
31 day & 0.000 & 0.000 \\
56 day & 0.009 & -0.022 \\
90 day & 0.022 & 0.004 \\
\hline
\end{tabular}

* Flowable fill stripped from mold after 14 days of sealed curing

Settlement Properties. Settlement is of concern for structural fill applications in that the fill materials must support substantial loads. ASTM D-2435 was employed to assess the settlement characteristics of the S-grade MDU flowable fill product. The testing indicated, as expected, that the MDU flowable fill product behaved more like a concrete than as a soil fill material. The testing indicated that the S-grade MDU flowable fill product supported loads in excess of 18 tons/square feet with no settlement.

\section{Environmental Properties of MDU Flowable Fill Materials}

Central to the acceptance of the MDU flowable fill material product are its environmental properties. These properties primarily relate to leachate characteristics and its impact on the adjacent soils. The environmental consequences of the use of the MDU flowable fill material were determined according to both standard methods and an environmental field simulator method developed by WRI.

Bulk Chemistry of the MDU Flowable Fill Product. The chemical composition of the Heskett fly ash and the E-grade MDU flowable fill material is presented in Table 13. The Heskett ash, shown for comparison, is similar to a number of ashes produced by the fluidizedbed combustion of low-sulfur coals. The high-alkali (sodium) content is indicative of the sodium found in the low-ranked lignite coals. The trace metal concentrations presented in Table 13 show the relatively low concentrations of most metals of environmental concern. The concentrations of these metals do not appear to be of concern. 
Table 13. Major Element and Trace Metal Composition of the Heskett Fly Ash and MDU Flowable Fill Product

\begin{tabular}{|c|c|c|c|c|c|}
\hline & $\begin{array}{l}\text { Heskett } \\
\text { Fly Ash }\end{array}$ & $\begin{array}{l}\text { Ready-Fill } \\
\text { S Grade }\end{array}$ & $\begin{array}{l}\text { Trace } \\
\text { Metals, ppm }\end{array}$ & $\begin{array}{l}\text { Heskett } \\
\text { Fly Ash }\end{array}$ & $\begin{array}{c}\text { Ready-Fill } \\
\text { S Grade }\end{array}$ \\
\hline Ash, wt \% & 88.10 & 84.63 & Antimony, ppm & $<0.1$ & $<0.1$ \\
\hline LOI, wt \% & 11.90 & 15.37 & Arsenic, ppm & 21.65 & 6.95 \\
\hline $\mathrm{SiO}_{2}$, wt $\%$ & 26.94 & 58.04 & Berylium, ppm & 1.50 & 0.26 \\
\hline $\mathrm{TiO}_{2}$, wt $\%$ & 0.38 & 0.14 & Boron, ppm & 464 & 68.0 \\
\hline $\mathrm{Al}_{2} \mathrm{O}_{3}$, wt $\%$ & 8.02 & 5.68 & Cadmium, ppm & 0.33 & 0.13 \\
\hline $\mathrm{Fe}_{2} \mathrm{O}_{3}$, wt $\%$ & 4.49 & 3.69 & Chromium, ppm & 10.2 & 6.60 \\
\hline $\mathrm{CaO}, \mathrm{wt} \%$ & 20.77 & 11.14 & Cobalt, ppm & 3.45 & 2.90 \\
\hline $\mathrm{MgO}, \mathrm{wt} \%$ & 7.56 & 2.44 & Copper, ppm & 31.5 & 10.5 \\
\hline $\mathrm{Na}_{2} \mathrm{O}$, wt $\%$ & 3.74 & 1.47 & Lead, ppm & 11.8 & 4.55 \\
\hline $\mathrm{K} 2 \mathrm{O}$, wt \% & 0.63 & 1.42 & Mercury, ppm & 0.6058 & $<0.123$ \\
\hline $\mathrm{P}_{2} \mathrm{O}_{5}, \mathrm{wt} \%$ & 1.60 & 0.61 & $\begin{array}{l}\text { Molybdenum, } \\
\text { ppm }\end{array}$ & 3.00 & 1.95 \\
\hline $\mathrm{SO}_{3}, \mathrm{wt} \%$ & 10.48 & 1.42 & Nickel, ppm & 8.00 & 8.08 \\
\hline $\mathrm{MnO}, \mathrm{wt} \%$ & 0.15 & 0.11 & Selenium, ppm & 1.78 & $<0.2$ \\
\hline $\mathrm{BaO}, \mathrm{wt} \%$ & 0.57 & 0.09 & Silver, ppm & $<0.5$ & $<0.5$ \\
\hline $\mathrm{SrO}, \mathrm{wt} \%$ & 0.39 & 0.05 & Thallium, ppm & 0.20 & $<0.1$ \\
\hline Total & 97.62 & 101.67 & $\begin{array}{l}\text { Vanadium, ppm } \\
\text { Zinc, ppm }\end{array}$ & $\begin{array}{l}16.4 \\
63.0 \\
\end{array}$ & $\begin{array}{l}11.1 \\
57.5 \\
\end{array}$ \\
\hline Radioactivity (pCi & & & & & \\
\hline Uranium & 2.4 & \multicolumn{2}{|c|}{0.75} & & \\
\hline Gross Alpha & $1.42+/-0.09$ & \multicolumn{2}{|c|}{$0.845+/-0.07$} & & \\
\hline Radium 226 & $0.380+/-0.02$ & \multicolumn{2}{|c|}{$0.305+/-0.02$} & & \\
\hline Radium 228 & $0.195+/-0.04$ & \multicolumn{2}{|c|}{$0.085+/-0.035$} & & \\
\hline Comb. Ra226+228 & 0.275 & \multicolumn{2}{|c|}{0.39} & & \\
\hline
\end{tabular}

Standardized Leachate Tests. The determination of the environmental acceptability of a material is typically assessed through the use of the Toxicity Characteristic Leaching Procedure (TCLP). The Heskett fly ash and the MDU flowable fill product were subjected to the TCLP procedure and the results are presented in Table 14. The leachate from the Heskett FBC fly ash and the MDU flowable fill product meet the regulatory limits for metals as specified by RCRA, thereby resulting in a non-hazardous classification for both the raw fly ash, as well as the MDU flowable fill product. In fact, the TCLP leachate meets many of the Drinking Water Standards.

Table 14. TCLP Extract Composition of the Heskett Fly Ash and MDU Flowable Fill Products 


\begin{tabular}{|l|c|c|c|c|}
\hline & $\begin{array}{c}\text { RCRA } \\
\text { Limits }\end{array}$ & $\begin{array}{c}\text { Heskett } \\
\text { Fly Ash }\end{array}$ & $\begin{array}{c}\text { MDU } \\
\text { Flowable } \\
\text { Fill - S Grade }\end{array}$ & $\begin{array}{c}\text { MDU } \\
\text { Flowable } \\
\text { Fill - E Grade }\end{array}$ \\
\hline Arsenic, ppm & 5.0 & $<0.10$ & 0.006 & 0.016 \\
Barium, ppm & 100.0 & 0.768 & 0.753 & 0.444 \\
Cadmium, ppm & 1.0 & $<0.010$ & $<0.010$ & $<0.010$ \\
Chromium, ppm & 5.0 & $<0.008$ & 0.021 & $<0.008$ \\
Lead, ppm & 5.0 & $<0.200$ & $<0.100$ & $<0.100$ \\
Mercury, ppm & 0.02 & $<0.002$ & $<0.002$ & $<0.002$ \\
Selenium,ppm & 1.0 & $<0.100$ & $<0.200$ & $<0.200$ \\
Silver, ppm & 5.0 & $<0.010$ & $<0.010$ & $<0.010$ \\
pH & $<12.5$ & 11.8 & 11.0 & 9.9 \\
\hline
\end{tabular}

The Heskett fly ash and the MDU flowable fill product were also extracted with distilled water according to ASTM D-3987, "Standard Method for Shake Extraction of Solid Waste with Water," and the extract or leachate was analyzed. Although ASTM D-3987 states that the procedure is not intended to simulate field-leaching conditions, it does provide information concerning extracts that have not been adjusted with acetic acid, as in the case of TCLP. Table 15 summarizes the extract analyses comparing the results with the U.S. EPA standards for domestic and agricultural use.

The results of the ASTM D-3987 testing show that the extract levels for all constituents with the exception of $\mathrm{pH}$ are below the domestic and agricultural water standards. Even the raw fly ash extract meets the water quality standards with the exception of the $\mathrm{pH}$. As such, one would not expect any significant concentrations of these elements in the soils adjacent to the placement of the MDU flowable fill materials.

Table 15. Composition of MDU Ash and Flowable Fill Extracts Relative to U.S. EPA Water Quality Standards ${ }^{a}$

\begin{tabular}{|l|c|c|c|c|}
\hline & $\begin{array}{c}\text { Heskett FA }^{\mathbf{b}} \\
\text { D-3987 } \\
\text { Extract }\end{array}$ & $\begin{array}{c}\text { MDU } \\
\text { Flowable Fill } \\
\text { D-3987 } \\
\text { Extract }\end{array}$ & $\begin{array}{c}\text { EPA } \\
\text { Standard } \\
\text { (Domestic) }\end{array}$ & $\begin{array}{c}\text { EPA } \\
\text { Standard } \\
\text { (Agriculture) }\end{array}$ \\
& & & \\
\hline
\end{tabular}




\begin{tabular}{|c|c|c|c|c|}
\hline Lab pH & 12.7 & 12.2 & $6.5-9.0$ & $4.5-9.0$ \\
\hline $\operatorname{TDS}\left(180^{\circ} \mathrm{C}\right), \mathrm{mg} / \mathrm{L}$ & 6,240 & 839 & 500 & 2,000 \\
\hline \multicolumn{5}{|l|}{ Major Anions } \\
\hline Chloride, mg/L & 28 & 4.2 & 250 & 100 \\
\hline Sulfate, mg/L & 2,260 & 113 & 250 & 200 \\
\hline Nitrate as $\mathbf{N}, \mathbf{m g} / \mathrm{L}$ & 1.8 & $<1$ & 10.0 & \\
\hline Nitrite as $\mathbf{N}, \mathbf{m g} / \mathbf{L}$ & $<0.2$ & $<0.2$ & 1.0 & \\
\hline Sodium Adsorption Ratio & 6.66 & 1.34 & - & 8 \\
\hline Fluoride, mg/L & 2.03 & 0.16 & 2.4 & - \\
\hline \multicolumn{5}{|l|}{ Trace Metals, mg/L } \\
\hline Aluminum & 0.12 & 0.215 & - & 5.0 \\
\hline Arsenic & $<0.002$ & $<0.002$ & 0.05 & 0.1 \\
\hline Barium & 0.215 & 0.465 & 1.0 & - \\
\hline Berylium & $<0.0002$ & $<0.0002$ & - & 0.1 \\
\hline Boron & 0.45 & 0.14 & 0.75 & 0.75 \\
\hline Cadmium & $<0.0002$ & $<0.0002$ & 0.01 & 0.01 \\
\hline Chromium & 0.0090 & 0.0190 & 0.05 & 0.1 \\
\hline Cobalt & $<0.002$ & $<0.002$ & - & 0.05 \\
\hline Copper & $<0.002$ & $<0.002$ & 1.0 & 0.2 \\
\hline Iron & $<0.002$ & $<0.002$ & 0.3 & 5.0 \\
\hline Lead & 0.0111 & 0.0078 & 0.05 & 5.0 \\
\hline Manganese & $<0.002$ & $<0.002$ & 0.05 & 0.2 \\
\hline Mercury & $<0.0002$ & $<0.0002$ & 0.002 & - \\
\hline Nickel & $<0.002$ & $<0.002$ & - & 0.02 \\
\hline Selenium & 0.0149 & $<0.002$ & 0.01 & 0.02 \\
\hline Silver & $<0.01$ & $<0.01$ & 0.05 & - \\
\hline Zinc & 0.97 & 0.295 & 5.0 & 2.0 \\
\hline Uranium & $<0.0003$ & $<0.0003$ & 5.0 & 5.0 \\
\hline Vanadium & $<0.002$ & $<0.002$ & - & 0.1 \\
\hline \multicolumn{5}{|l|}{ Radioactivity, pCi/L } \\
\hline Comb. Radium $226 \& 228$ & $<1.2$ & $<1.2$ & 5 & 5 \\
\hline Total Strontium 90 & nd & nd & 8 & 8 \\
\hline Gross Alpha ${ }^{\mathrm{c}}$ & $<1$ & $<1$ & 15 & 15 \\
\hline
\end{tabular}

${ }^{a}$ EPA National Primary Drinking Water Regulations

${ }^{\mathrm{b}} \mathrm{FA}$ - Fly Ash

${ }^{\mathrm{c}}$ Includes Radium 226 but excludes Radon and Uranium

(-) indicates no standard

nd - not determined, na - not available

Environmental Field Simulation Tests. The standardized leaching tests commonly used (TCLP or ASTM D-3987) do not address the field conditions of the MDU flowable fill material and its interaction with the adjacent soils and ultimately its impact on field water quality and plant species. Field condition concerns arise because of the relatively high levels of sodium in the Heskett ash and the known adverse impact of sodium on plant productivity. One of the concerns of using MDU flowable fill material containing high-sodium fly ash is the potential migration of sodium and other salts into adjacent materials resulting in saline and sodic 
conditions. Some concern may also be associated with sulfate-containing solutions migrating from the MDU flowable fill material into surface and groundwater systems. It is this interface between the placed MDU flowable fill material and the adjacent soils that determines the environmental impact of MDU flowable fill material on the environment.

In order to assess the field conditions and the interface with soils in the laboratory, WRI developed a method termed an Environmental Field Simulator (EFS). A schematic of the laboratory-scale EFS is presented in Figure 2.

The Environmental Field Simulator employs the use of a modified flexible-wall permeameter to produce a permeate or leachate separate from the MDU flowable fill product and the adjacent soil. This simulator also allows for the determination of the permeability of the MDU flowable fill product and the permeability of the soil in the interface zone.

The Environmental Field Simulator was designed to allow the interaction of the MDU flowable fill product with adjacent soil to determine whether solution migrated from the fill to the soil material. The field simulation used in the testing program consisted of a 2-inch diameter flowable fill specimen surrounded by one inch of soil material, resulting in a total diameter of four inches. The 4-inch core specimen was placed in a flexible-walled permeameter and water was allowed to flow through the system. A leachate collection system was developed to separately collect leachate from the flowable fill and the soil material.

Impact of MDU Flowable Fill Product on Adjacent Soils. Testing was conducted using S-grade and E-grade MDU flowable fill products, local North Dakota soil, and the WRI EFS. Solution samples collected from the S-grade flowable fill product were evaluated for electrical conductivity (EC), sodium adsorption ratio (SAR), and sulfate $\left(\mathrm{SO}_{4}^{-2}\right)$ concentrations. These data are shown in Figure 3.

The values for each parameter are presented as a function of water/solids ratios on a cumulative basis. The water/solids ratio provides an indication of the amount of water that has contacted the MDU flowable fill product on a per weight basis. The data show an initial bleeding of salts from the MDU flowable fill product into the adjacent soil as evidenced by increases in $\mathrm{EC}, \mathrm{SO}_{4}^{-2}$, and $\mathrm{SAR}$ values in the permeates. As additional water contacted the materials (or as the water/solids ratio increased), the $\mathrm{EC}$ values and the $\mathrm{SO}_{4}{ }^{-2}$ concentrations associated with both the S-grade MDU flowable fill material and the adjacent soils decreased. 


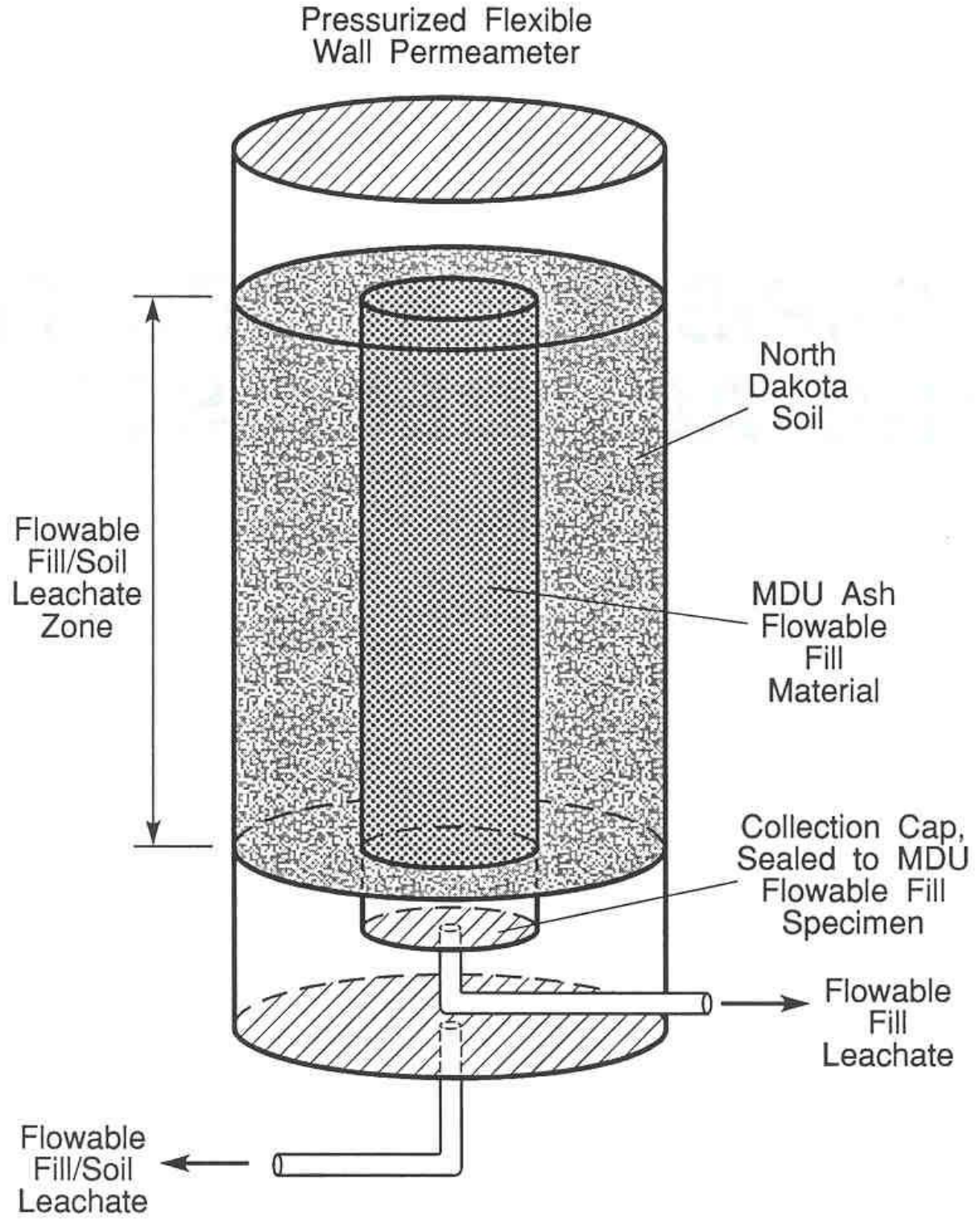

Figure 2. Schematic of the WRI Environmental Field Simulator

The SAR values of the soils adjacent to the MDU flowable fill product changed from about 2.4 to 13 at lower water/solids ratios, decreasing to about 12 as the water/solids ratio approached 2.0 (Figure 3). At the same time, the SAR values associated with the leachate from the S-grade MDU flowable fill product changed from an initial level of about 12 to 5 at a water/solids ratio of 0.4 followed by an increase to about 8.0 at a water/solids ratio of about 2.0. The data show that the soil immediately adjacent to the MDU flowable fill product was somewhat impacted by the S-grade MDU flowable fill product. This could be viewed as a positive result in that soils characterized by SAR values of about 13 and EC values of about $0.5 \mathrm{mS} / \mathrm{cm}$ tend to slake and disperse, resulting in the formation of impermeable material between the MDU flowable fill 
product and the environment. Basically, the MDU flowable fill product is encapsulated, preventing movement of water into or out of the system.
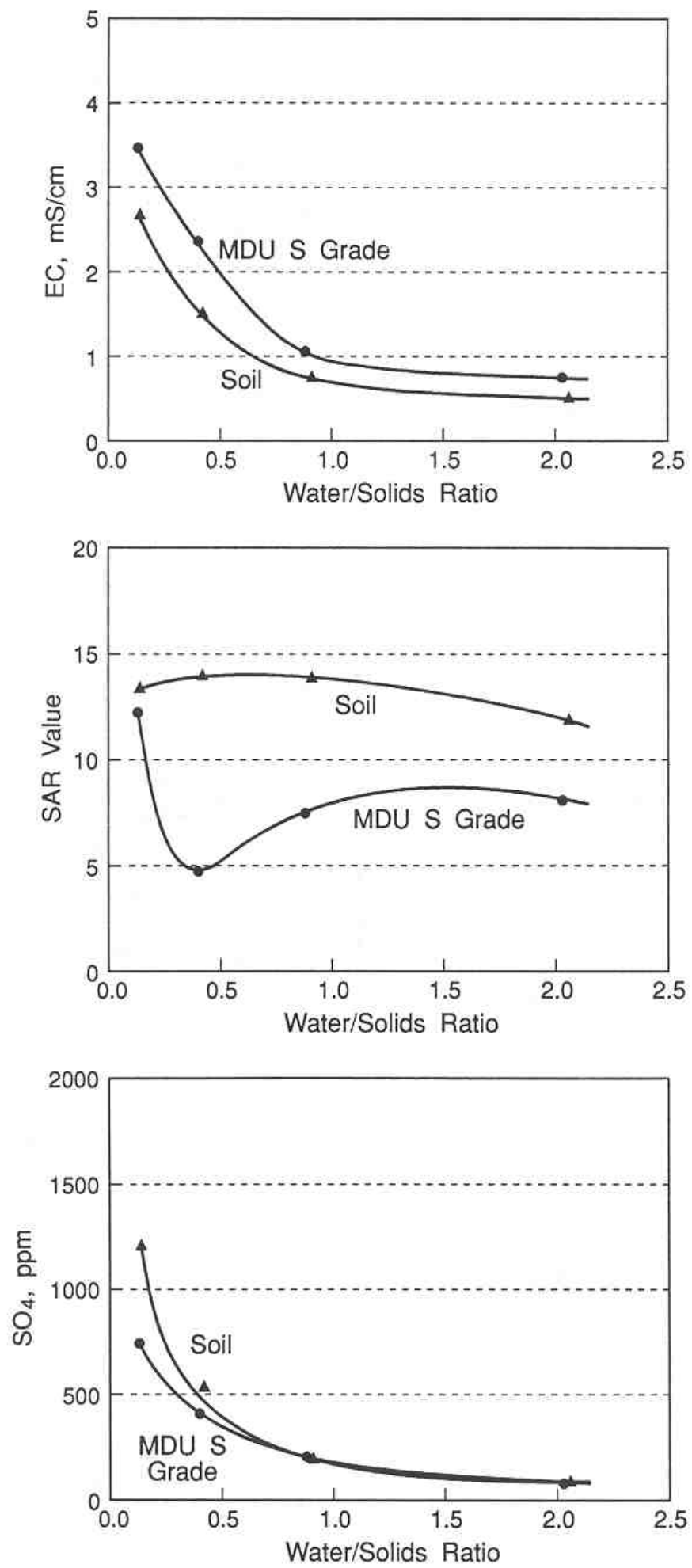

Figure 3. Chemical Impact of MDU Flowable Fill Product on Adjacent Soils from Environmental Field Simulator Tests 
Excavated and Rubblized MDU Flowable Fill Product Environmental Tests. Another concern of using MDU flowable fill product was that if the MDU flowable fill product was excavated from a site and left in a rubblized form at the surface, it could potentially result in salinity and sodicity problems of the nearby surface soils. An attenuation study was performed using the E-grade MDU flowable fill product to address this issue. The tests were conducted using the procedure as shown in Figure 4, wherein the initial permeameter was filled with a 50:50 mix of rubblized MDU flowable fill product (crushed to $3 / 4$ inch) and soil followed by two permeameters filled with soil connected in series. In other words, leachate solutions collected from the rubblized MDU flowable fill product column (4-inch diameter by 4 inches long) were applied to Soil-1 column (4-inch diameter by 2 inches long) and solution leaching through Soil-1 was passed through the Soil-2 column (4-inch diameter by 2 inches long).

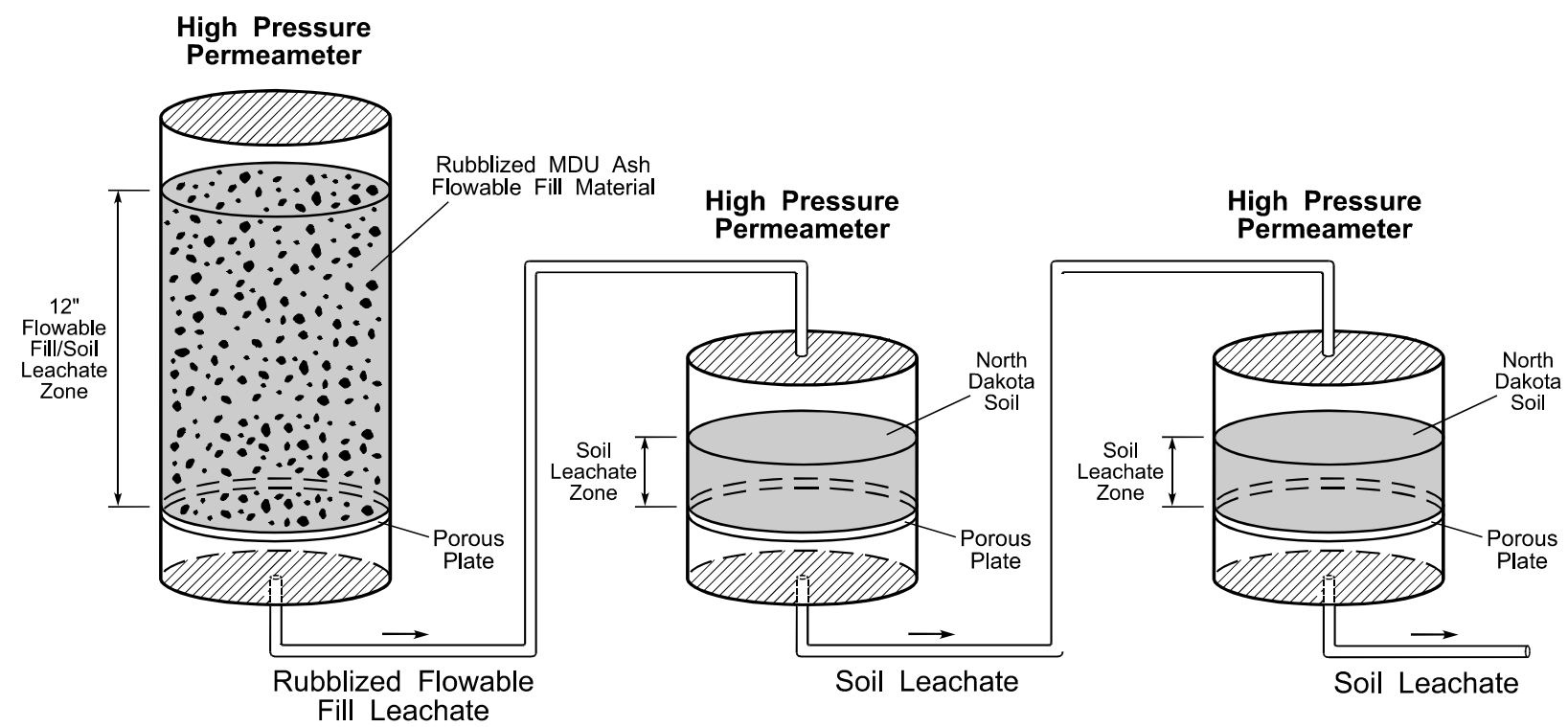

Figure 4. Schematic of the Rubblized MDU Flowable Fill Product Environmental Field Simulator Attenuation Tests

Solutions collected from each permeameter were evaluated for EC, SAR, and $\mathrm{SO}_{4}{ }^{-2}$, and the results are presented in Figure 5 as a function of the water/solids ratio. As the water/solids ratio increased, $\mathrm{EC}$ and $\mathrm{SO}_{4}{ }^{-2}$ decreased in the rubblized MDU flowable fill product/soil mixture because of leaching while the SAR values remained relatively constant. These same relationships were found in the leachates from the rubblized E-grade MDU flowable fill product/soil rubble material and both Soil-1 and Soil-2 materials. There was probably attenuation of the chemical constituents by the soil in the soil/MDU flowable fill product rubble as well as in the adjacent soil columns. 

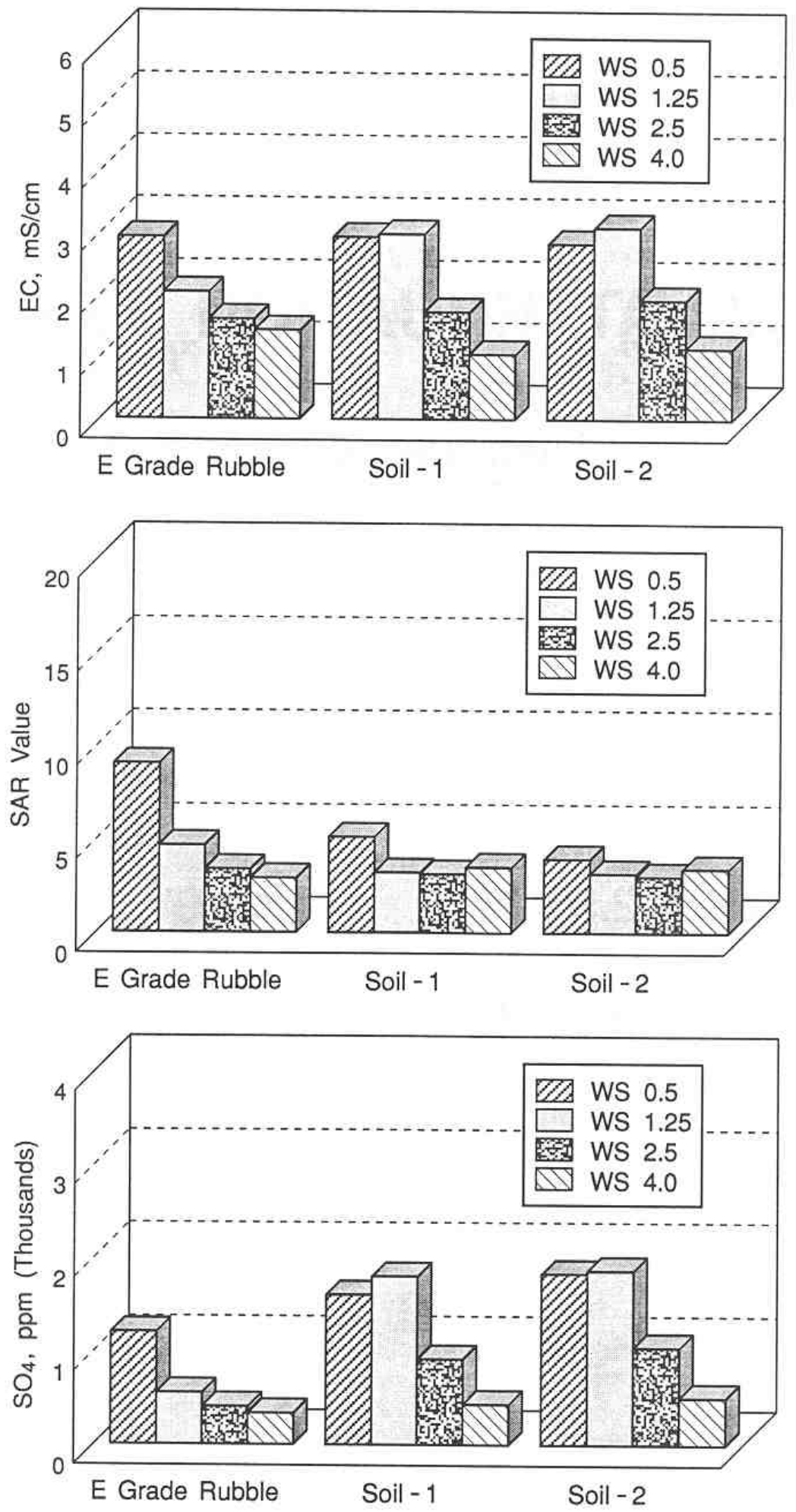

Figure 5. Chemical Effects of Rubblized MDU Flowable Fill on the Adjacent Soils Resulting from the Environmental Field Simulator 
In addition to the attenuation of the sodicity-causing constituents in the leachate by the soil, there was also a reduction of the hydraulic conductivity of the adjacent soil, which would prevent the movement of leachates from the fill to adjacent materials. The water applied to the rubblized E-grade MDU flowable fill product and soil mixture readily leached through the column within a day. The solution from the rubblized E-grade MDU flowable fill product and soil mixture column caused significant reductions in hydraulic conductivity of Soil-1 as it permeated through it. The hydraulic conductivity of Soil-1 was reduced from about $6.0 \times 10^{-5}$ $\mathrm{cm} / \mathrm{s}$ to about $2.0 \times 10^{-9} \mathrm{~cm} / \mathrm{s}$ (Table 17). The solution exiting Soil-1 did not result in substantial changes in the hydraulic conductivity of Soil-2 as it ranged from about $6.6 \times 10^{-5} \mathrm{~cm} / \mathrm{s}$ to $2.4 \mathrm{x}$ $10^{-5} \mathrm{~cm} / \mathrm{s}$. The non-impacted soil hydraulic conductivity ranged from $9.6 \times 10^{-7}$ to $2.0 \times 10^{-6}$. As shown in Table 16, the hydraulic conductivity of Soil-2 is about $6.0 \times 10^{-5} \mathrm{~cm} / \mathrm{s}$ at the 4.0 water/solids level of leaching.

\section{Table 16. Hydraulic Conductivity of Soils Adjacent to Rubblized MDU Flowable Fill} Product Leachate

\begin{tabular}{|l|c|c|}
\hline & \multicolumn{2}{|c|}{ Hydraulic Conductivity, cm/s } \\
\cline { 2 - 3 } & $\begin{array}{c}\text { First 2 Inches of Adjacent Soil } \\
\text { (Soil 1) }\end{array}$ & $\begin{array}{c}\text { Second 2 Inches of Adjacent Soil } \\
\text { (Soil 2) }\end{array}$ \\
\hline Permeate 1 & - & $1.2 \times 10^{-5}$ \\
Permeate 2 & $6.0 \times 10^{-9}$ & $7.0 \times 10^{-6}$ \\
Permeate 3 & $2.5 \times 10^{-9}$ & $1.4 \times 10^{-5}$ \\
Permeate 4 & $2.0 \times 10^{-9}$ & $6.0 \times 10^{-5}$ \\
\hline
\end{tabular}

The data from the rubblized MDU flowable fill product tests suggest that an initial flush of solution from the rubblized E-grade column contained high levels of sodium that caused sodic conditions in Soil-1, resulting in clay swelling and dispersion of clays. The sodic condition is probably associated only with the soils that were first contacted with the initial flush of solution from the rubblized MDU flowable fill product/soil mixture column. The soils impacted were dispersed and the hydraulic conductivity of these soils was significantly reduced, forming an impermeable barrier between the impacted zone and the material below it in the column. In fact, the hydraulic conductivity of the impacted materials equates to that required for clay liners used at hazardous material disposal sites. The material below or down gradient from the impacted sodic soils found in the Soil-1 column probably had a hydraulic conductivity very similar to that found in Soil-2 column soils. There is strong evidence that the initial flush of solution from the rubblized E-grade MDU flowable fill material resulted in the encapsulation of itself in the MDU flowable fill product rubble/soil mixture as well as in the initial contacted soils in the soil column, thereby preventing any significant interaction of solution outside the initial point of impact (probably $<1.0$ inch). The solution from rubbilized or solid MDU flowable fill product should not migrate into adjacent soils or water resources.

Embed Compatibility Study 
The presence of alkalis and sulfates in the leachate from MDU flowable fill material was a concern because of its potential to cause corrosion of embeds that could be placed in the MDU flowable fill material. WRI employed a method that involved the embedding of coupons of various materials of construction (Portland cement, Portland cement with Class F fly ash, rebar, copper pipe, black pipe, and galvanized conduit) in the MDU flowable fill material and then subjecting it to wet-dry cycles for up to one year. Two and a half cycles of wet-dry were achieved every week. One would expect approximately six to eight wet-dry cycles per year under field conditions in the Bismarck, North Dakota area. Therefore, one is able to simulate a year of field conditions in approximately three weeks.

Multiple sets of mixes and coupons have been fabricated to allow the coupons to be examined after varying ages. The results are presented in Figure 6. After a year of wet-dry cycles, each embed coupon was washed and examined for pitting or other evidence of corrosion. This is equivalent to approximately 17 years of service under field conditions. The results of the embed testing confirmed that the MDU flowable fill product does not appear to be detrimental to any of the embed materials.
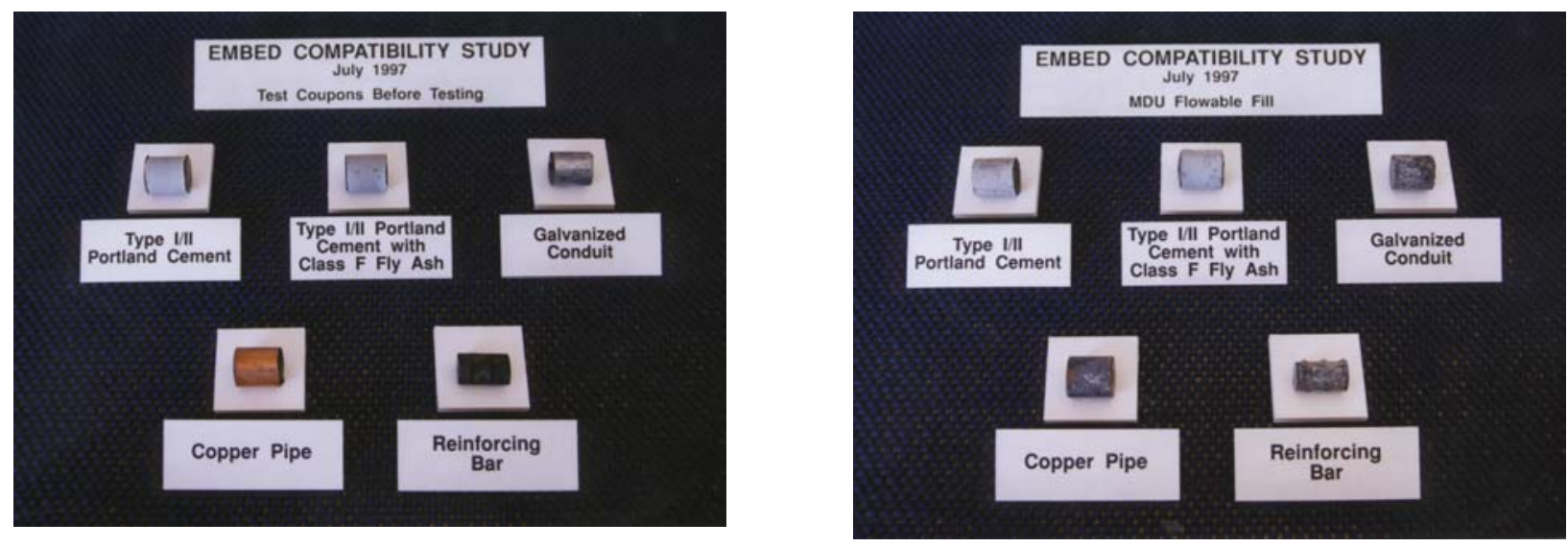

Figure 6. Photographs of the Embed Coupons Before and After Being Exposed to Wet/Dry Cycling in MDU Flowable Fill 


\section{Results of Phase III - Demonstration and Monitoring Activities (Tasks 3 and 4)}

Based on the positive geotechnical and environmental performance of the MDU flowable fill materials as described in Phase II, WRI and MDU conducted a series of preliminary field demonstrations of the MDU flowable fill materials. The demonstrations had the following objectives:

- Assess the placement characteristics of the flowable fill materials in full-scale field conditions;

- Assess the geotechnical and environmental performance under real field conditions;

- $\quad$ Assess the impact of the flowable fill materials on potential embed materials; and

- Assess the excavatability of the fill material after months of curing under winter conditions.

Several demonstrations were conducted that address the structural-grade MDU flowable fill material, as well as the excavatable-grade (trench filling) MDU flowable fill applications. These demonstrations were intended to verify the potential of the MDU flowable fill material using full-scale equipment, from both an engineering and environmental perspective. The size of the demonstrations was designed to be sufficient to assess the economic benefits of MDU flowable fills, as well as the technical performance of the MDU flowable fill materials.

Arrangements were made with Atlas Ready-Mix to assist in the preparation of truck-size quantities of the MDU flowable fill materials. A silo was erected to handle the MDU fly ash. The silo and the weigh system are presented in Figure 7.
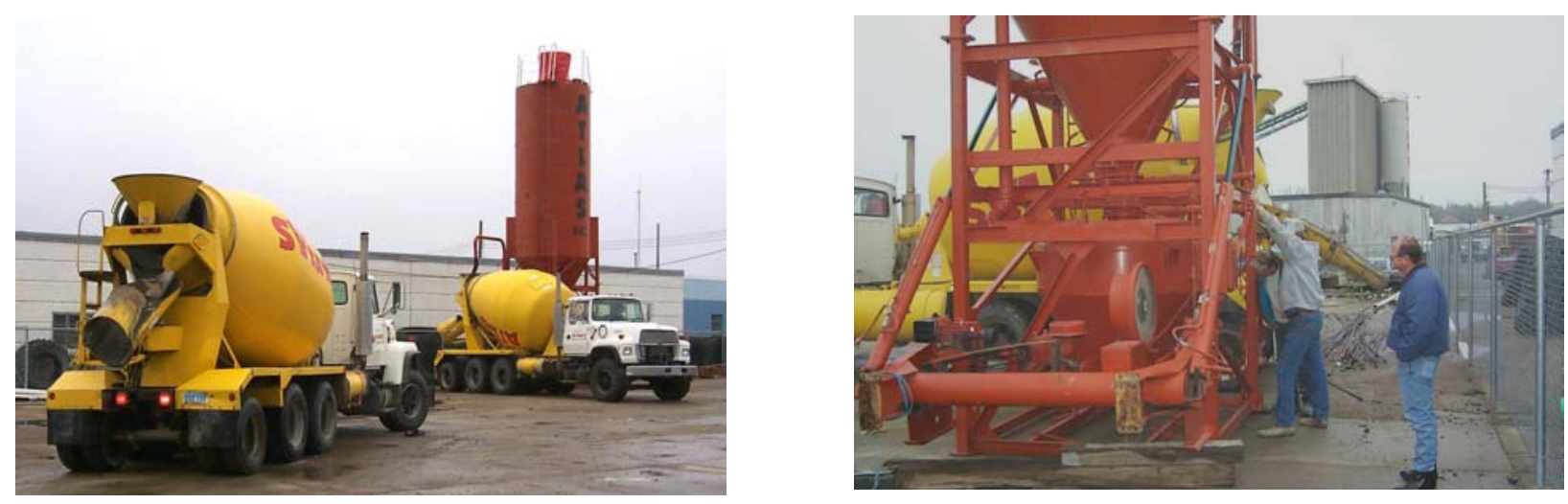

Figure 7. Photographs of the MDU Fly Ash Silo and Weigh System Erected at Atlas Ready-Mix for the Demonstrations 
Approximately 12 tons of MDU fly ash was transported and placed in the silo at Atlas Ready-Mix for the tests. The cement used in the demonstration was the cement used by Atlas for their ready-mix business. Unfortunately, due to the material handling logistics at the Atlas Ready-Mix Company, WRI was unable to use the off-spec sand used in the laboratory-testing portion of the program. Instead, the concrete sand used by Atlas for the ready-mix concrete business was employed. The sand used had a larger particle size distribution and therefore the water requirements were expected to vary from the laboratory testing.

A total of four flowable fill mixes was used in the demonstrations. These included one structural S-grade and three different strength excavatable E-grade fill materials. Following is a summary of the results of the structural- and excavatable-grade demonstrations.

\section{$\underline{\text { Structural-Grade Fill Demonstration }}$}

Site Description. The demonstration site selected for the structural-grade MDU fill demonstration was the coal rail car unloading area at the MDU Heskett plant. Photographs of the site are shown in Figure 8. The demonstration site layout is presented in Figure 9. The site was essentially a base fill around the rail car loadout area that receives front-end loader traffic that pushes the coal rail cars into position for loadout and front-end loader traffic that adds secondary coal to the coal hopper. It was proposed that the MDU structural-grade fill material would be poured at a nominal 1-foot thickness in the vacinity of the loadout area. A concrete slab of approximately 8 inches thick was to be poured over part of the fill. This left two types of conditions for the fill; (1) strictly a base for a concrete slab that would receive the traffic load, and (2) an area that was to be covered with dirt and would receive the front-end loader traffic.
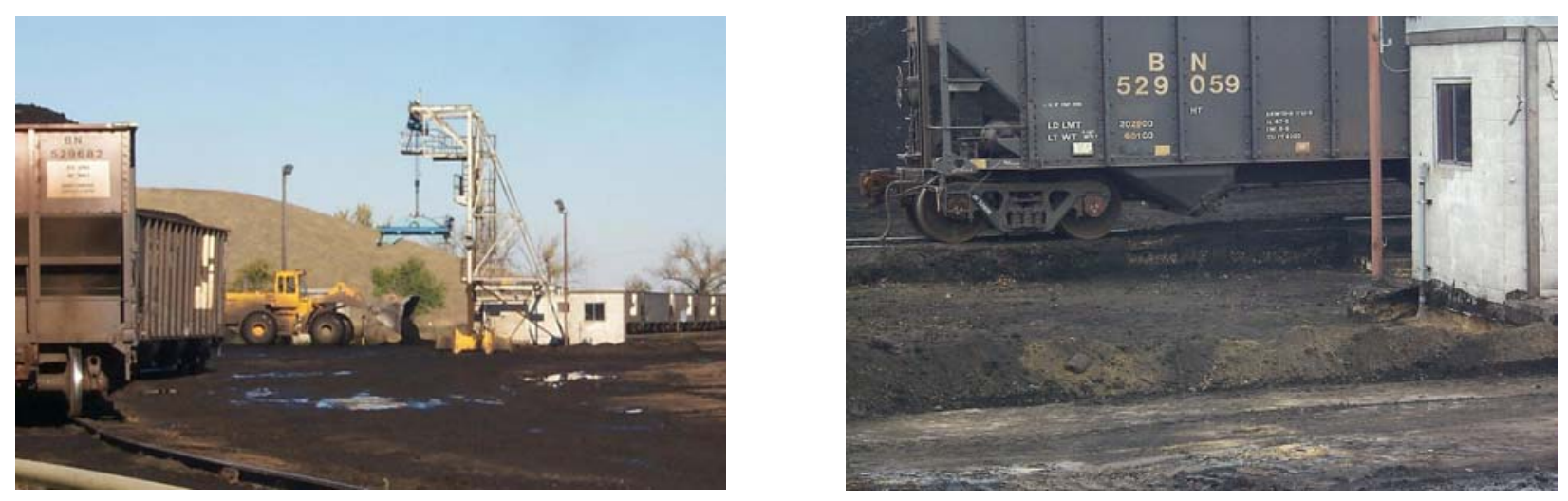

Figures 8. Photographs of the Rail Car Load Area Prior to the Demonstration Activities 


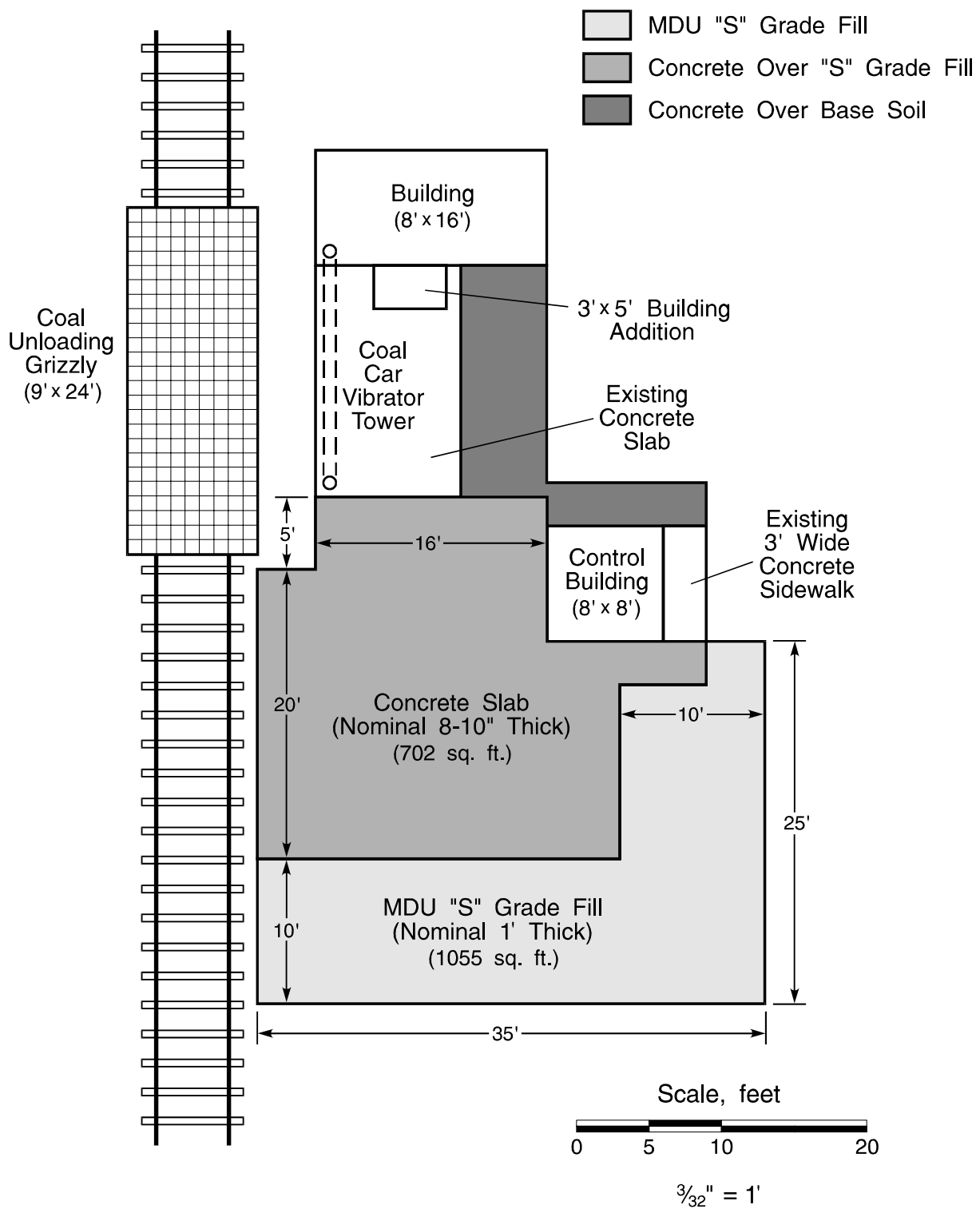

Figure 9. Site Layout for the Structural-Grade Fill Demonstration

Demonstration Construction. The demonstration was conducted on October 16, 1999. The weather conditions at the time of the fill construction were cold $\left(0-5{ }^{\circ} \mathrm{C}, 32-41{ }^{\circ} \mathrm{F}\right)$ and rainy. Atlas Ready-Mix personnel stated that they would pour in these conditions. Therefore, this represents real-world conditions. Approximately 48 cubic yards in 8 -yard batches were produced at the Atlas facility. Eight-yard loads were used instead of the usual 10-yard loads because of harsh mud conditions that the trucks encountered in getting to the unloading area. The mix proportions are presented in Table 17. 
Table 17. Mix Proportions for the Structural Fill Demonstration

\begin{tabular}{|l|c|}
\hline Mix Components (pcy) & S-Grade Mix $^{\mathbf{1}}$ \\
\hline Atlas Concrete Sand & 2,306 \\
Atlas Cement & 150 \\
MDU Fly Ash & 363 \\
Water (gal/cubic yard) & 65 \\
Flow (inches) & $\sim 8-9$ inches \\
\hline${ }^{1}$ pcy - pounds per cubic yard \\
\hline
\end{tabular}

Hot water was used for the mix water at the plant, as is the custom for Atlas for pouring under these cold conditions. Figures 10 and 11 show the placement of the S-grade fill into the site. The 48 cubic yards were poured in approximately 40 minutes, indicating the speed at which the MDU fill material can be placed.

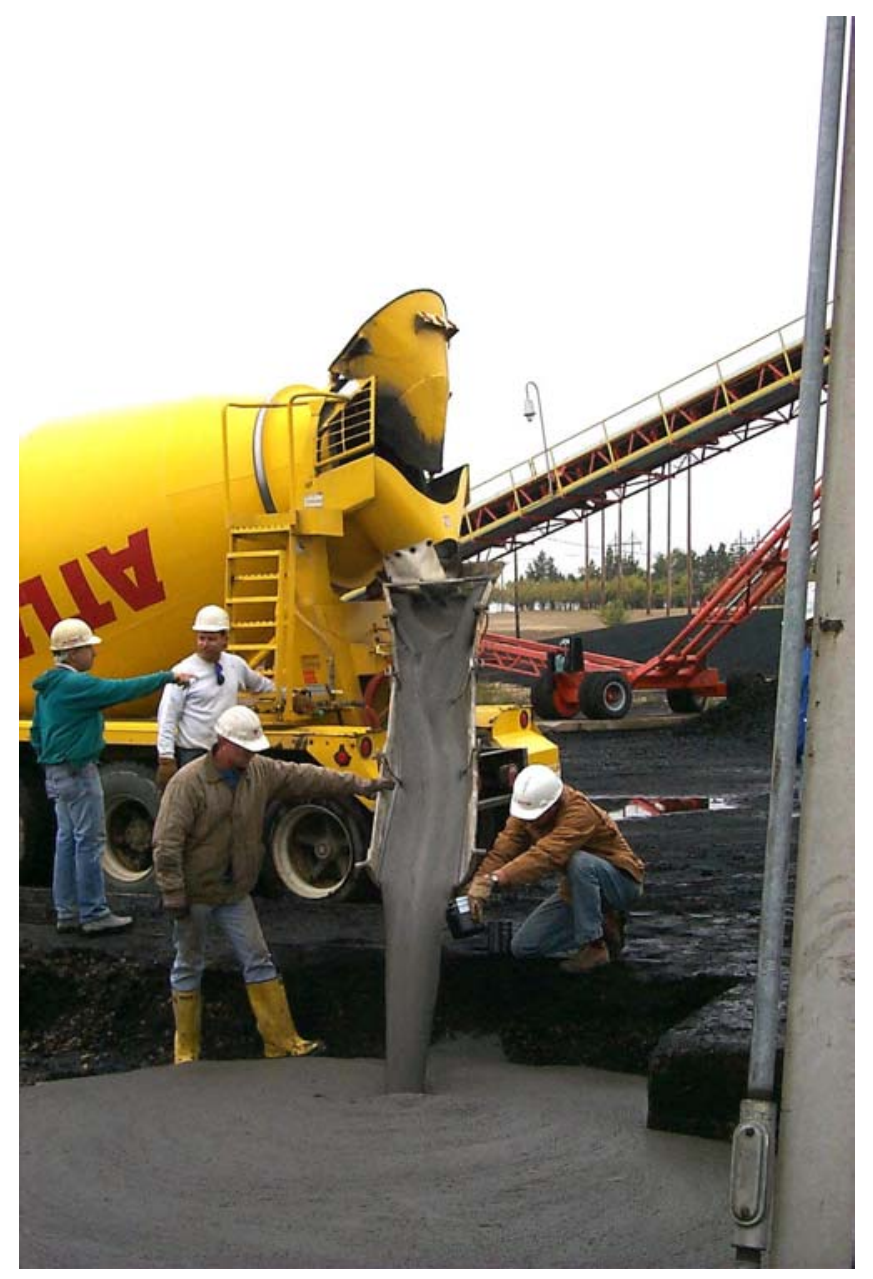

Figure 10. Placement of the Structural-Grade Fill 
The flow of the mix was quite adequate with the fill moving approximately 25 feet or more with little assistance. The material was leveled with a rake, leaving slight ridges and irregularities to the surface. This was desired because of the fact that it provides a better interface with the concrete overlay or the soil cover. The fill had standing water in some of the low places and was subjected to near freezing conditions the first night. However, the mix generates heat, preventing freezing of the mixture and assisting strength development.
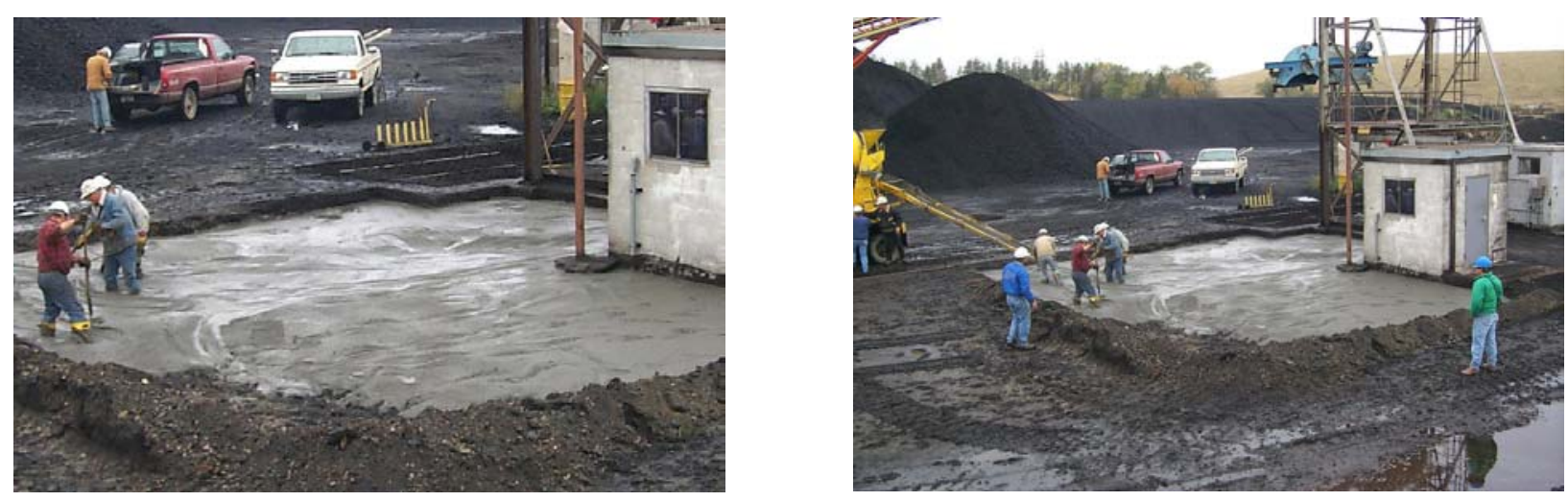

Figure 11. Placement of the Structural-Grade Fill

The S-grade fill was allowed to cure for one week and a contractor was hired to set forms and pour the concrete overlay. The stakes were driven into the fill and the forms were set. Figures 12 and 13 show the setting of the forms for the concrete pour. The contractor was very pleased with the performance of the fill and stated that this material makes an outstanding base fill for concrete work.

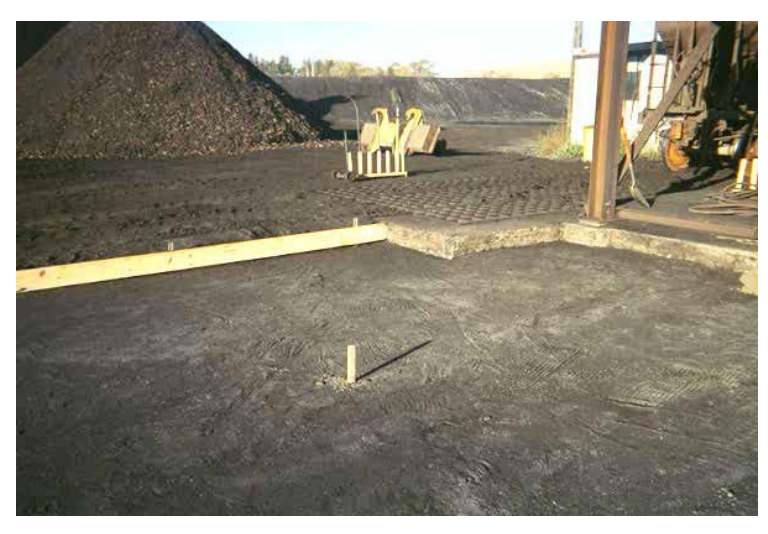

Figure 12. Setting of the Forms for the Concrete Pour

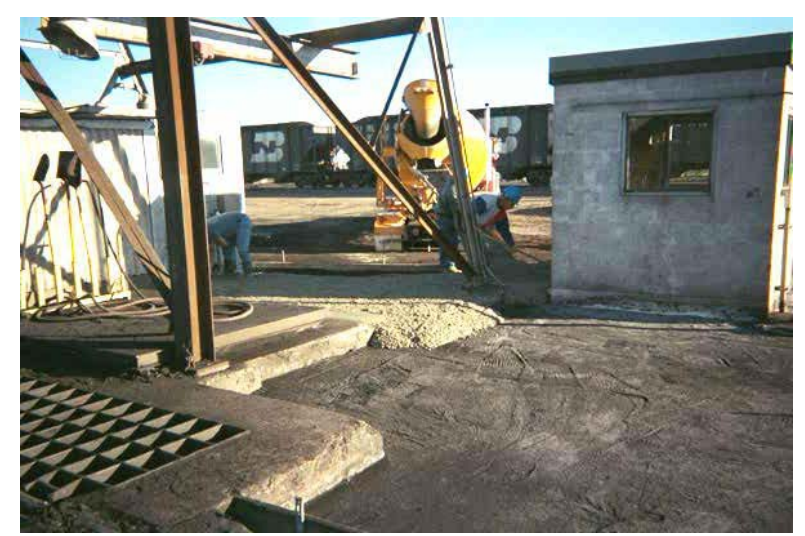

Figure 13. Concrete Pour at StructuralGrade Flowable Fill Demonstration Site 
Post-Construction Inspection. The site was monitored and the setting conditions of the fill were visually inspected. The fill developed strength and stiffened within 8 to 10 hours. The fill was capable of supporting the weight of workmen by the next morning (approximately 20 hours). Figure 14 shows the condition of the fill after 20 hours curing. Although it was cold overnight, the heat from the fill kept it well above the freezing point.
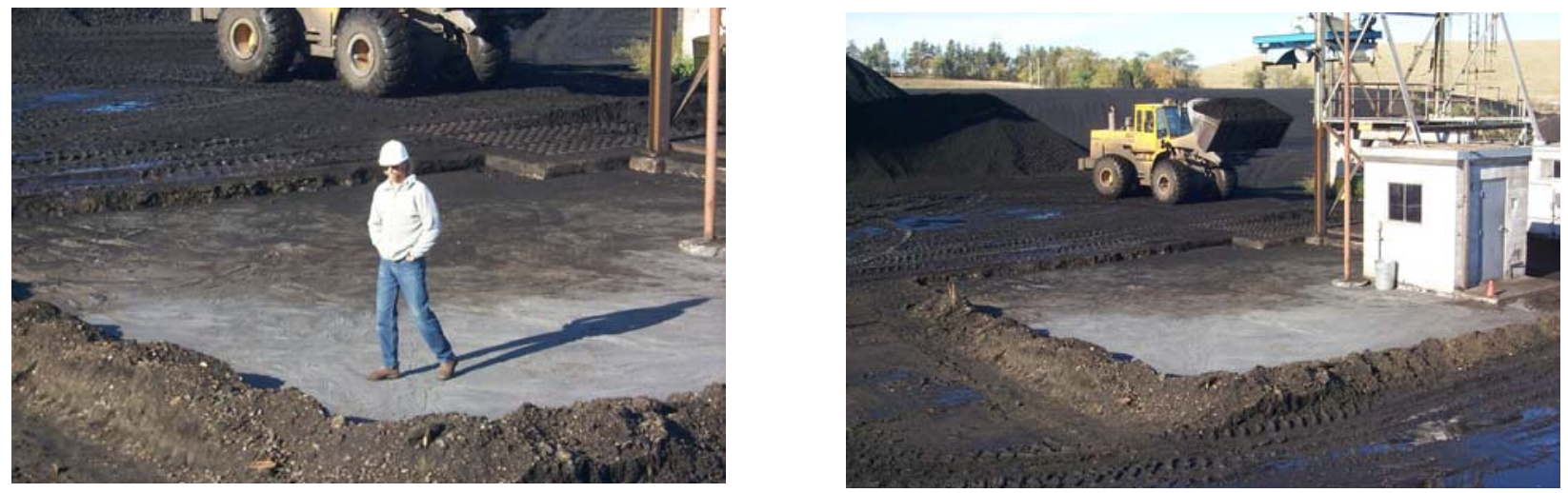

Figure 14. Condition of the Structural-Grade Flowable Fill Twenty Hours After Placement

Small, shallow, drying cracks were noted the next morning. Examination of the cracks indicated that they were shallow (less that 1-2 inches deep) and were the result of drying. They had no impact on the strength or geotechnical properties of the fill. However, they could become a source for freeze-thaw damage. Figure 15 shows these cracks.
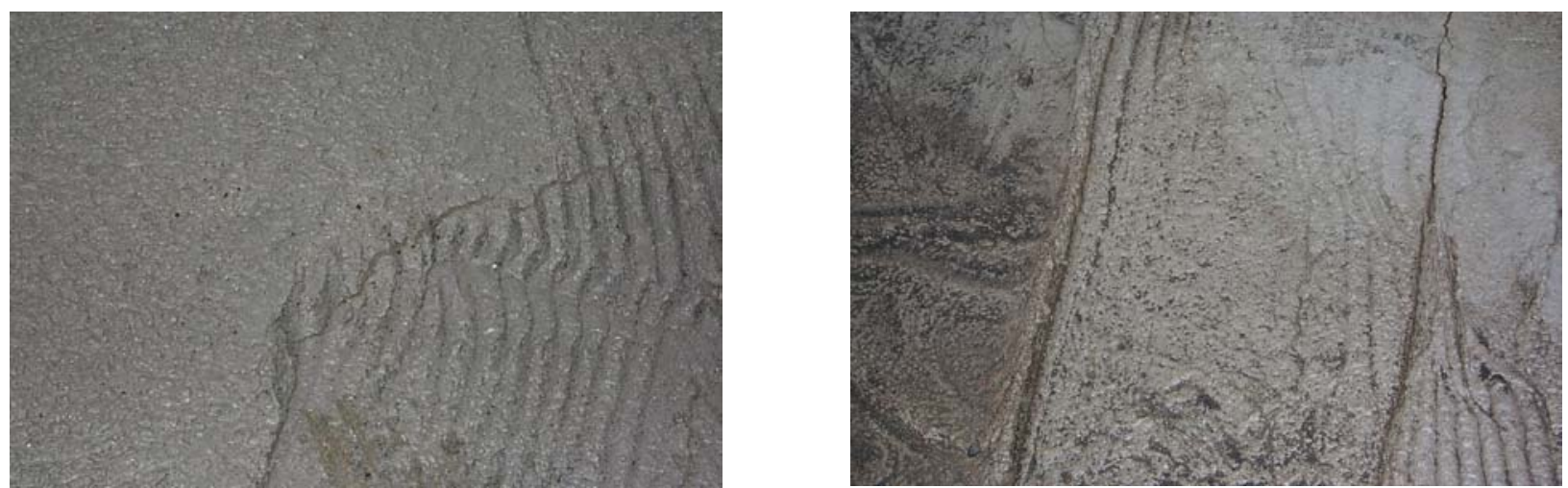

Figure 15. Photographs of the Surface Cracks that Developed on the Structural-Grade Fill

The site was inspected on at least two different occasions after the site was placed into service. These inspections extended out to 7 months. Figure 16 shows the site under service. The fill showed no evidence of deterioration from the front-end loader service. Workers were 
very pleased with the finished product and would like to see the placement of the S-grade fill down both sides of the rail tracks.

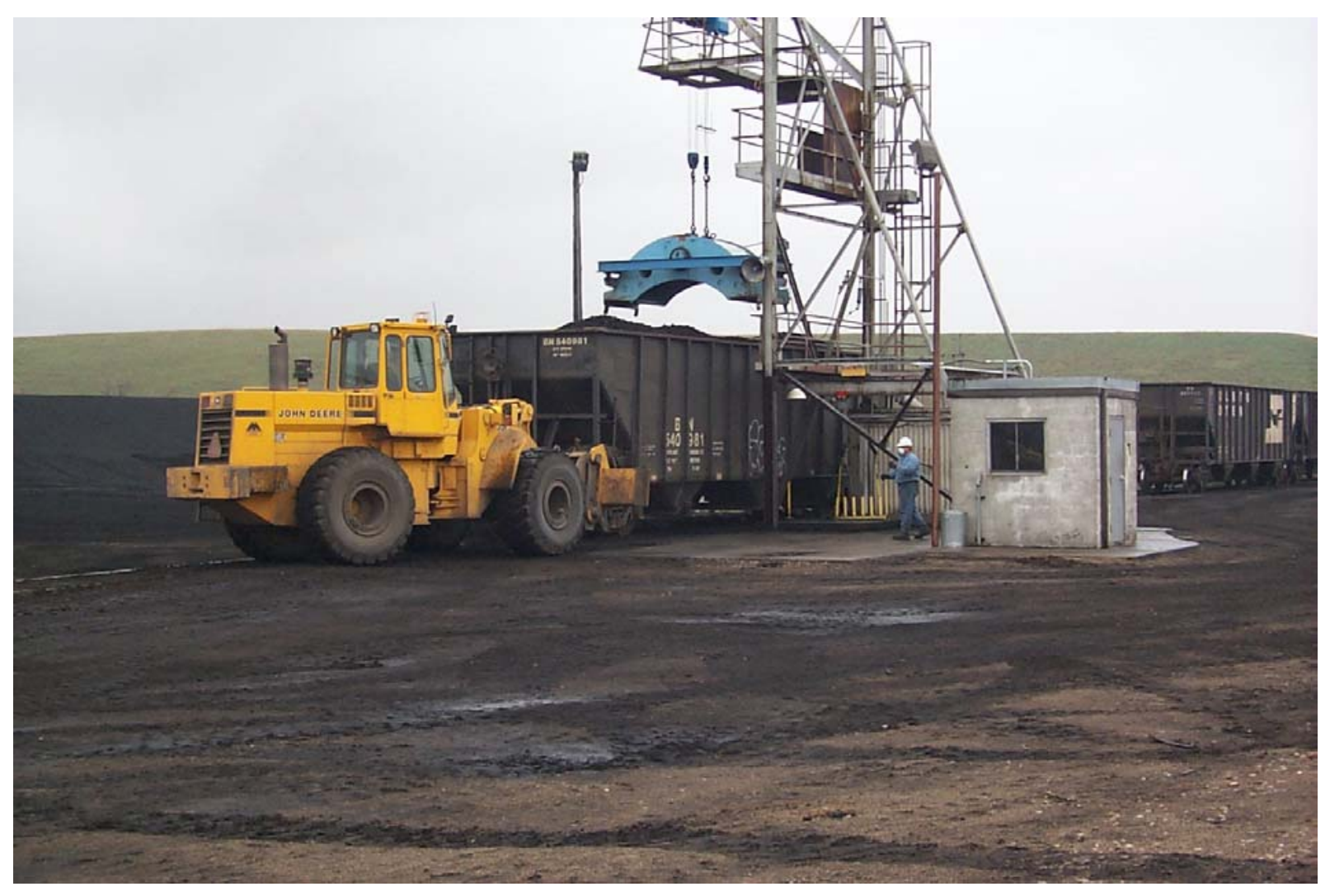

Figure 16. Post-Construction Service of the Structural-Grade Fill Site

Geotechnical Properties. Samples were collected for set time and strength testing of the S-grade fill and cured at $72{ }^{\circ} \mathrm{C}\left(161{ }^{\circ} \mathrm{F}\right)$ and at cold, ambient conditions. The cold, ambient conditions were sealed to prevent rain or snow from contacting the sample and were kept at the outside temperature (approximately $0-5{ }^{\circ} \mathrm{C}, 32-41{ }^{\circ} \mathrm{F}$ ). Figure 17 shows the collection and fabrication of test specimens in the field. The results of the testing are presented in Table 18. 

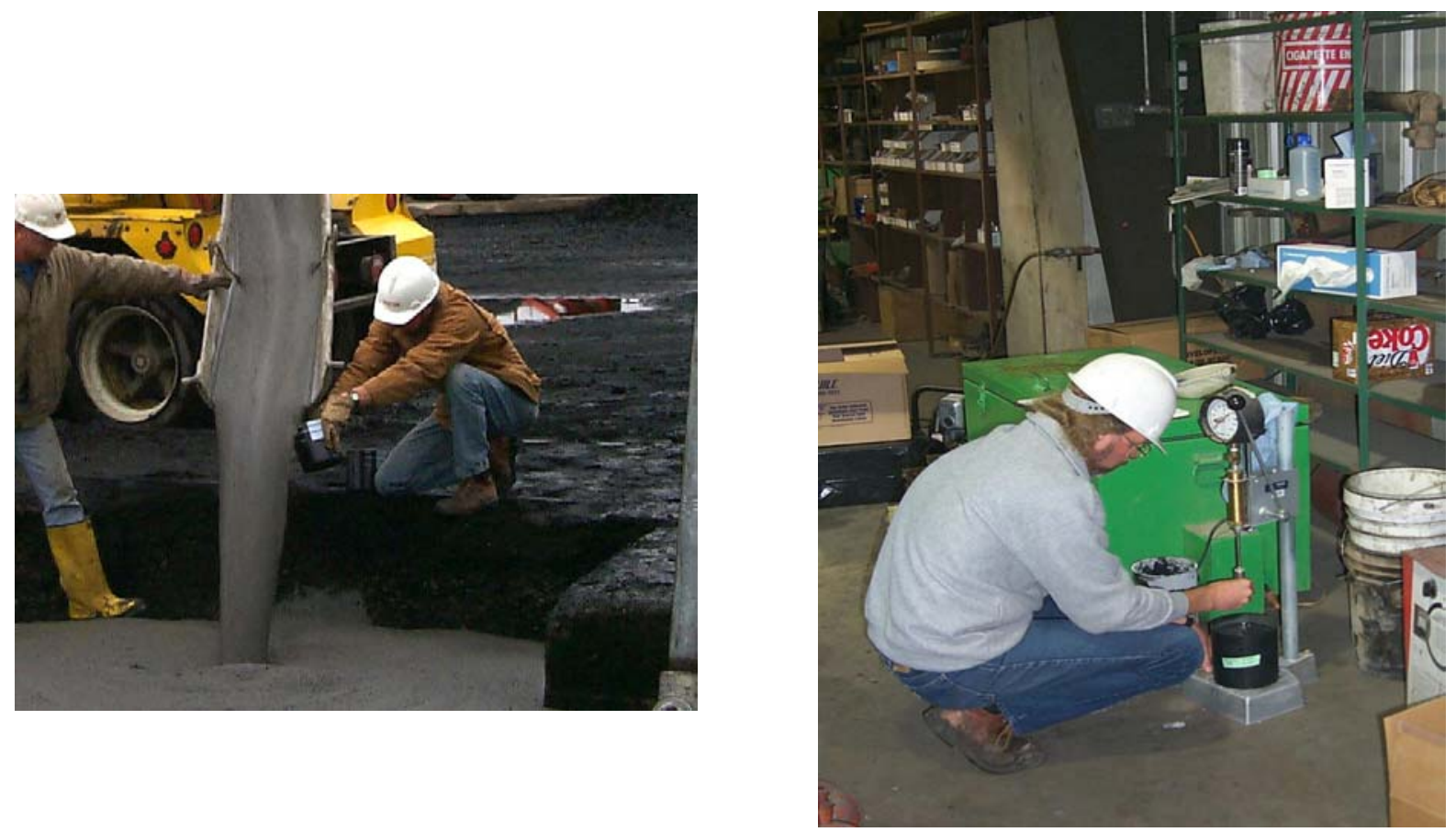

Figure 17. Collection and Testing of Flowable Fill Materials in the Field

Table 18. Results of the Geotechnical Properties of the Structural-Grade Fill Materials Cured Under Different Curing Conditions

\begin{tabular}{|c|c|c|}
\hline $\begin{array}{l}\text { Flowable Fill } \\
\text { Property }\end{array}$ & $\begin{array}{c}\text { S Grade } \\
\left(7^{\circ} \mathrm{F} \text { Curing) }\right.\end{array}$ & $\begin{array}{c}\text { S Grade } \\
\text { (cold, ambient curing) }\end{array}$ \\
\hline Flow (inches) & $8-9$ inches & $8-9$ inches \\
\hline Density (pcf) & $125.3 \mathrm{pcf}$ & $125.3 \mathrm{pcf}$ \\
\hline \multicolumn{3}{|c|}{ Set Time (penetration resistance, psi) } \\
\hline 24 hours & 1,488 & 64 \\
\hline 3 days & $>6,400$ & 544 \\
\hline \multicolumn{3}{|c|}{ Unconfined Compressive Strength (psi) } \\
\hline 7 days & 745 & 120 \\
\hline 28 days & 993 & 538 \\
\hline 90 days & 1,170 & na \\
\hline 180 days & 1,344 & na \\
\hline
\end{tabular}

na - not available

The S-grade fill demonstration was a success, clearly demonstrating the properties and performance of the flowable fill material using the MDU fly ash.

Excavatable-Grade Fill Demonstrations 
Site Description. Due to the experimental nature of the excavatable MDU flowable fill material, a commercial field demonstration site was not available. However, the city of Bismarck engineers showed interest and visited later while the MDU Gas Transmission group also showed interest and were on site to witness the demonstrations.

A total of three demonstrations were conducted and the demonstrations were made using trenches constructed at the MDU Heskett plant. Two of the demonstrations consisted of trenches 3 feet deep, 24 inches wide, and approximately 40 feet long. The other demonstration was a trench 6 feet wide, 4-5 feet deep, and 15 feet in length. The difference in the shape of the trenches was due to the availability of equipment. The first two trenches were constructed using a backhoe, while the third trench was constructed using a front-end loader. Figures 18 and 19 show the construction of the trenches for the E-grade demonstrations.
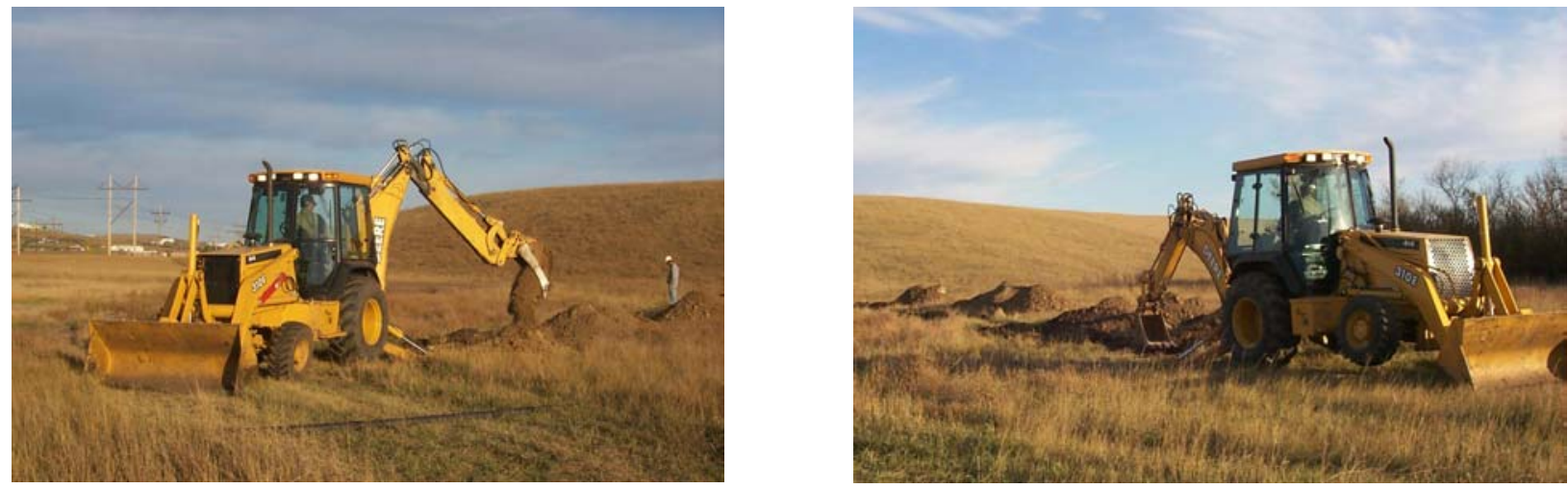

Figure 18. Construction of the Trenches for the 30E and 60E Demonstrations
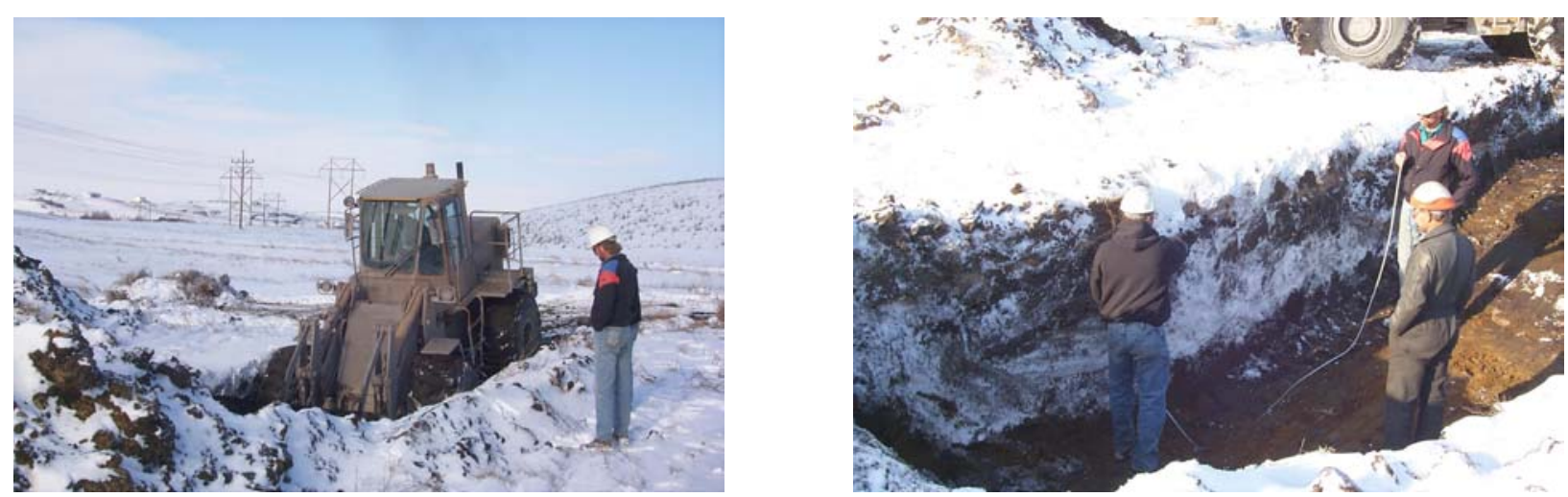

Figure 19. Construction of the Trench for the E200 Fill Demonstration 


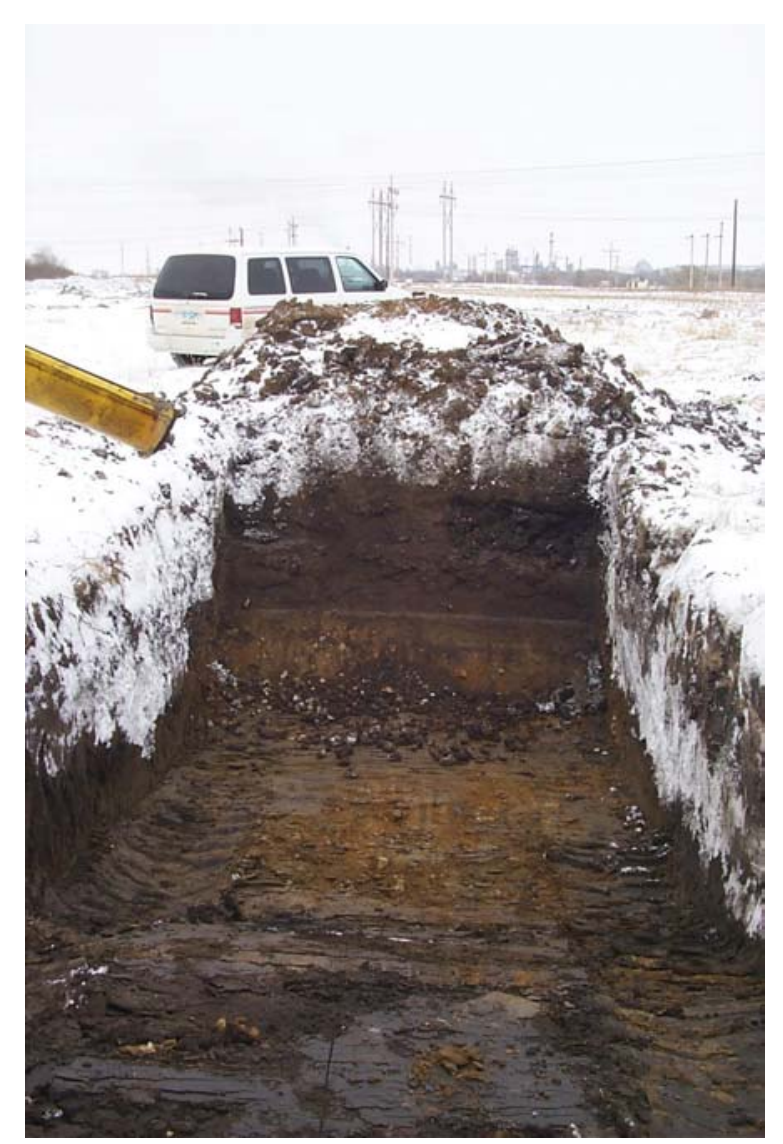

Figure 20. Construction of the Trench for the E200 Fill Demonstration

Demonstration Construction. The demonstration was conducted in October and November 1999. The weather conditions at the time of the fill construction were cold $\left(0-5{ }^{\circ} \mathrm{C}\right.$, $\left.32-41^{\circ} \mathrm{F}\right)$ and rainy in October and cold $\left(-6-2^{\circ} \mathrm{C}, 20-35^{\circ} \mathrm{F}\right)$ and snowing in November. Atlas Ready-Mix personnel stated that they would pour in these conditions. Therefore, this represents real-world conditions.

Approximately eight cubic-yard batches were produced at the Atlas facility. As with the S-grade fill demonstration, 8-yard loads were used instead of the usual 10-yard loads because of harsh mud conditions that the trucks encountered in getting to the unloading area. Three different mixes were demonstrated as part of the excavatable fill demonstration. The mix proportions are presented in Table 19. 
Table 19. Mix Proportions for the Excavatable Fill Demonstrations

\begin{tabular}{|l|c|c|c|}
\hline Mix Components & 60E Grade & 30E Grade & 10E200 Grade \\
\hline Atlas Concrete Sand (pcy) & 2,264 & 2,264 & 2,405 \\
MDU Fly Ash (pcy) & 63 & 30 & 10 \\
Atlas Cement (pcy) & 350 & 350 & 200 \\
Water (gal/cubic yard) & 76 & 74 & 87 \\
Flow (inches) & $\sim 8.0-9.0$ & $\sim 8.0-9.0$ & $\sim 7.5-9.0$ \\
\hline
\end{tabular}

In addition to the MDU flowable fill material, typical embed materials were also obtained and embedded in the $60 \mathrm{E}$ and $30 \mathrm{E}$ fill demonstration materials. The purpose of these embeds was to ascertain some real condition evaluations of the corrosivity of the fill material and the embed materials. Typical pipe, flanges, valves, and plastic conduit were used in the tests. Figure 21 shows placement of the flowable fill around the embeds and the embed materials prior to placement in the fill materials. A site plan and cross sections of the three excavatable flowable fill demonstrations are presented in Figure 22.
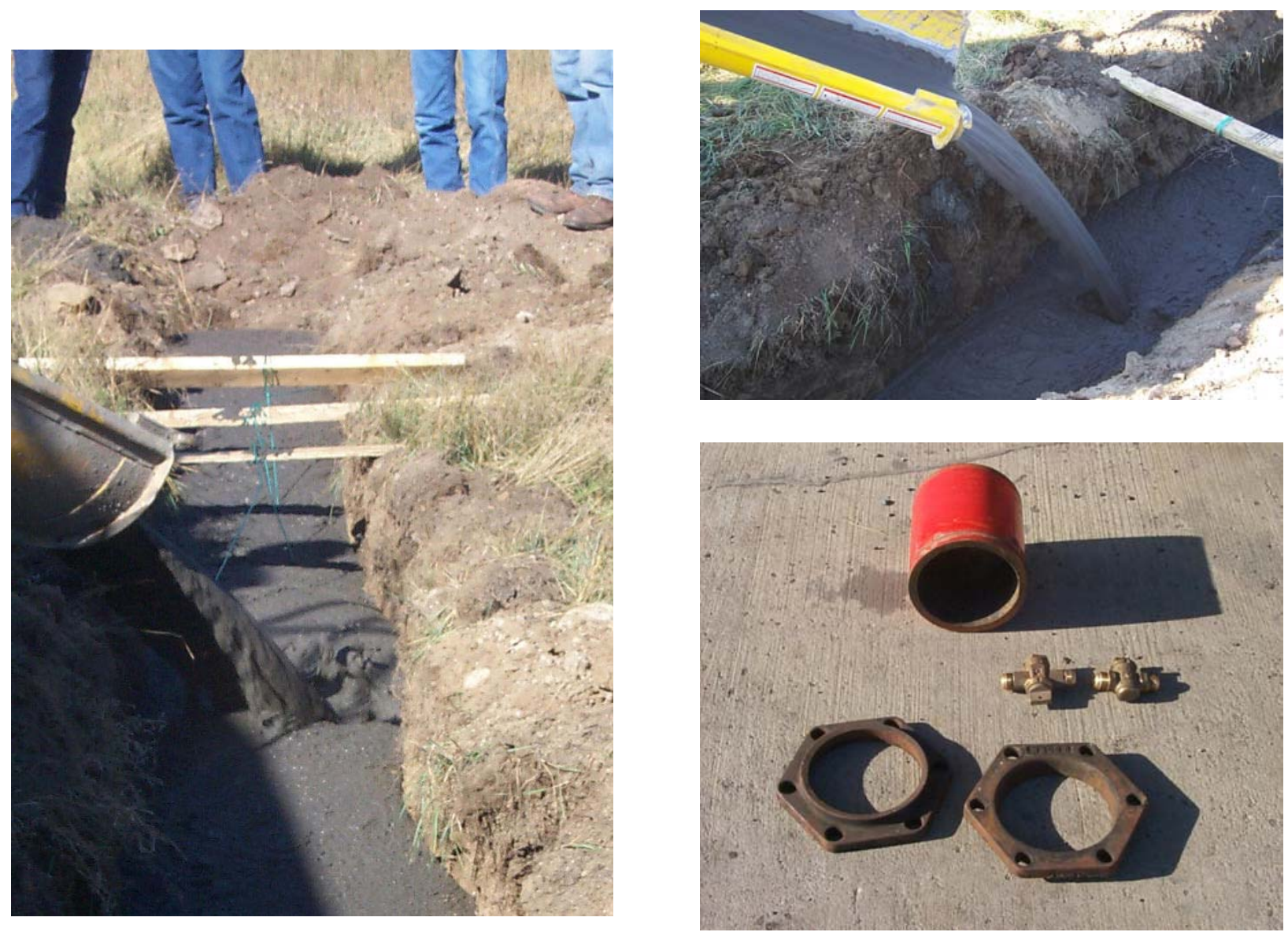

Figure 21. Photographs of Embed Materials and Placement in the Demonstration Fills 

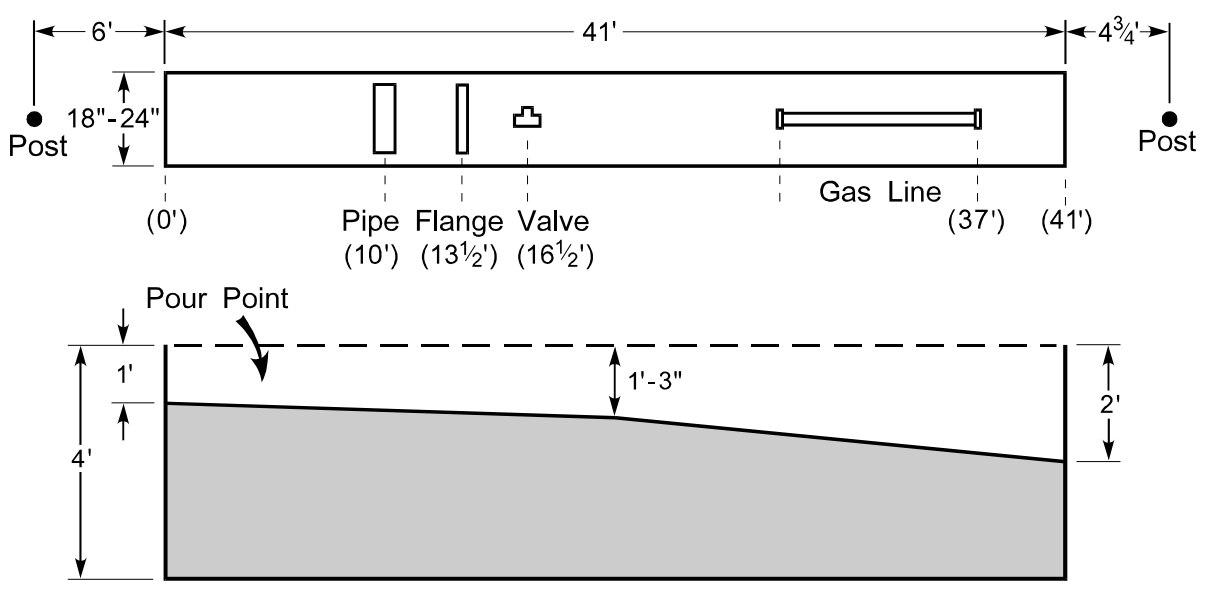

60 "E"

Grade
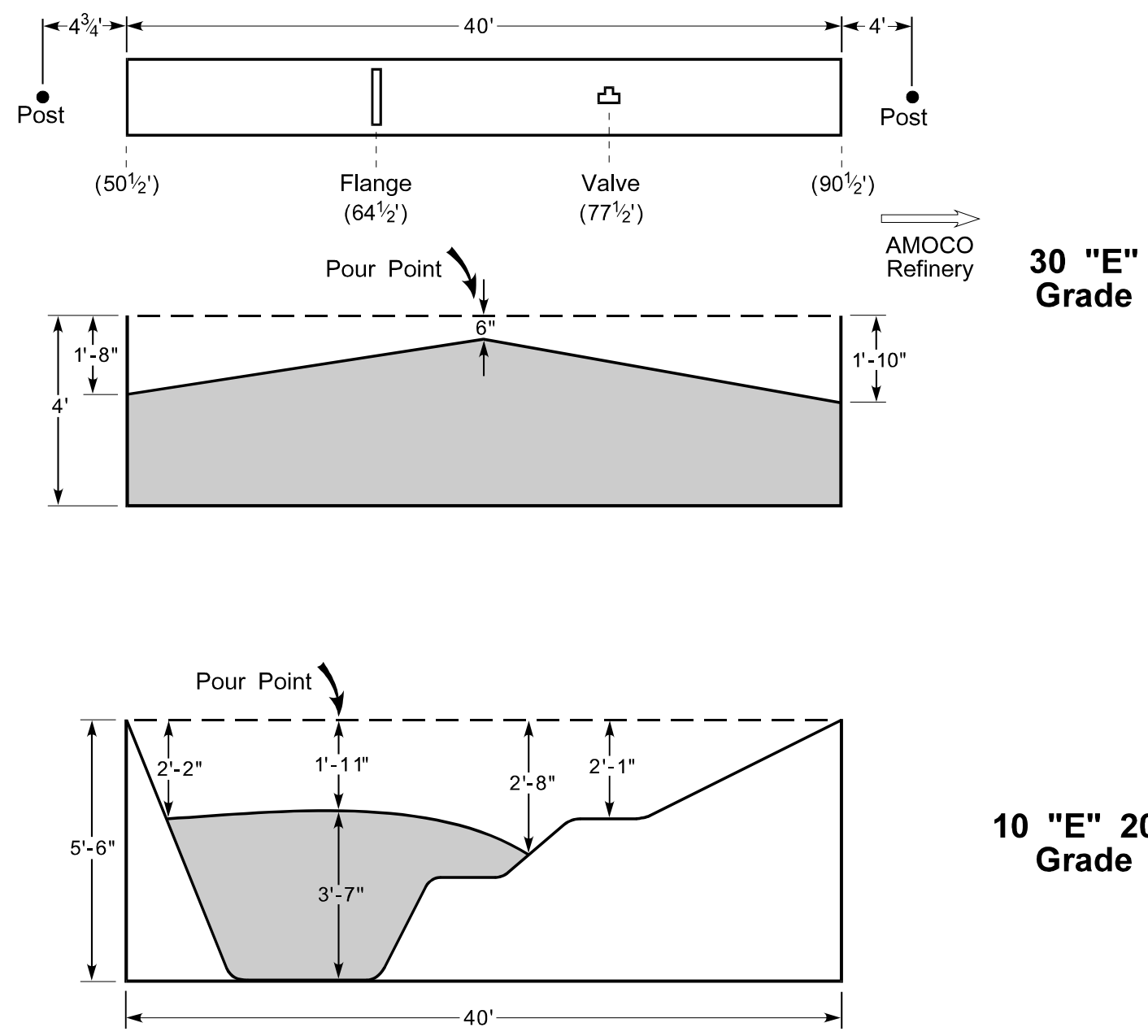

10 "E" 200

Grade

Figure 22. Site Plans and Cross Sections for the Excavatable Demonstrations 
The 10E200 flowable fill demonstration involved the placement of approximately 16 cubic yards of fill material. The weather was snowy and cold and represented worse-case placement and curing conditions. Figure 23 shows the placement of the 10E200-grade MDU flowable fill material in the excavated trench.
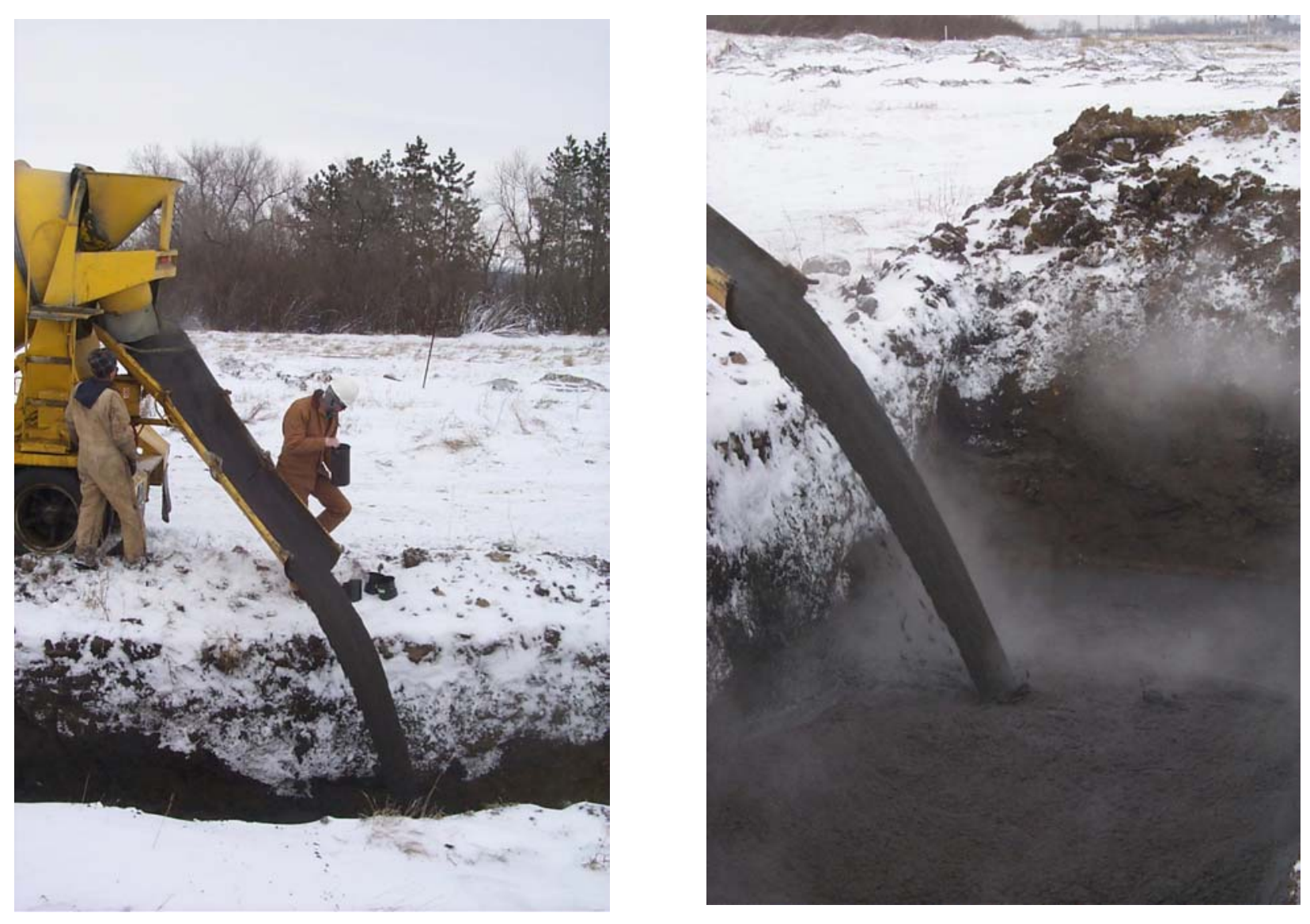

Figure 23. Photographs of the Placement of the 10E200 Flowable Fill Material at the Demonstration Site

Geotechnical Properties. Samples were collected for set time and strength testing of the various E-grade fill and cured at $72{ }^{\circ} \mathrm{C}\left(161.6^{\circ} \mathrm{F}\right)$ and at cold, ambient conditions. As with the Sgrade test specimens, the cold, ambient conditions were sealed to prevent rain or snow from contacting the sample and were kept at the outside temperature (approximately $0-5{ }^{\circ} \mathrm{C}, 32-41$ ${ }^{\circ} \mathrm{F}$ ). In addition, the temperature of the fill materials was monitored as curing took place (Figure 24). Figure 25 shows the collection and fabrication of test specimens in the field. The results of the testing are presented in Table 20. 


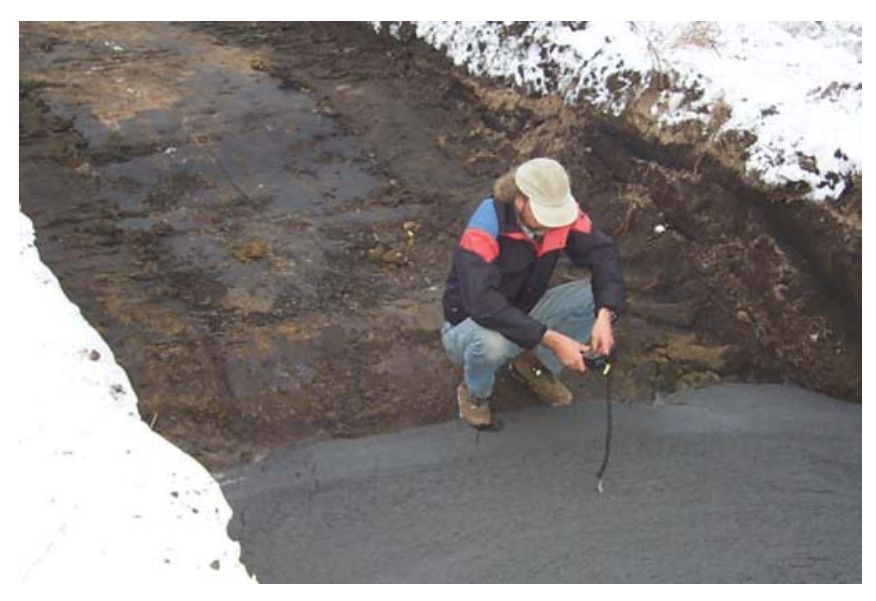

Figure 24. Monitoring of the Temperature of the 10E200 Flowable Fill After Placement

Post-Construction Inspection. Each of the fill demonstrations were covered within 48 hours, typical of trench filling construction. The demonstrations were allowed to age in the covered state over the winter and were excavated during April 1999. The inspections had several technical objectives, including:

- $\quad$ Assess the short-term performance (geotechnical properties) of the fill materials;

- $\quad$ Assess the excavatability of the fill materials;

- Assess the long-term geotechnical properties;

- $\quad$ Assess the mobility of components of the fill material into the adjacent soils; and

- $\quad$ Assess the compatibility of typical embeds with the fill materials.
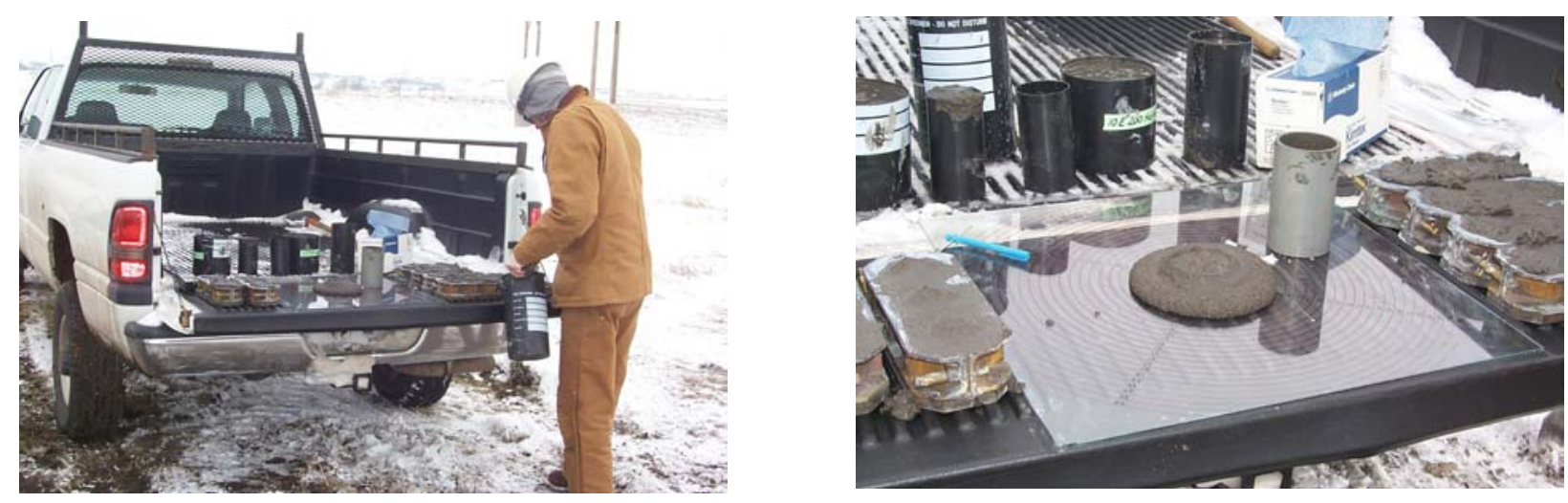

Figure 25. Collection and Fabrication of Test Specimens in the Field During the 10E200 Demonstration 
Table 20. Geotechnical Properties of the Excavatable-Grade Fill Materials Cured Under Different Curing Conditions

\begin{tabular}{|l|c|c|c|}
\hline $\begin{array}{l}\text { Geotechnical } \\
\text { Property }\end{array}$ & $\begin{array}{c}\text { 60E } \\
\text { Grade }\end{array}$ & $\begin{array}{c}\text { 30 E } \\
\text { Grade }\end{array}$ & $\begin{array}{c}\text { 10E200 } \\
\text { Grade }\end{array}$ \\
\hline Flow (inches) & $7.0-8.0$ & $7.0-8.0$ & $7.5-9.0$ \\
Density (pcf) & 122.8 & 120.9 & 125.8 \\
Set Time (penetration resistance, psi) & & & \\
$\quad 24$ hours & 176 & 48 & 44 \\
$\quad 3$ days & 4,160 & 1,328 & 520 \\
Unconfined Compressive Strength (psi) & & & \\
$\quad 7$ days at $73^{\circ} \mathrm{F}$ & $464(36)$ & $231(21)$ & $13(4)$ \\
28 days & $649(103)$ & $353(130)$ & $101(63)$ \\
90 days & $744(\mathrm{na})$ & $491(\mathrm{na})$ & 125 (na) \\
\hline
\end{tabular}

${ }^{1}$ Cured at $73^{\circ} \mathrm{F}$ and outside

na - not available

Short-term Performance of the Fill Material. Each of the E-grade flowable fill demonstrations was visited to determine the short-term strength development regarding the capability to support people and the ability to cover the flowable fill materials within a two-day time frame. Figure 26 shows the capability of the 30E grade to support a person within 16-20 hours. A similar performance was also achieved for the 60E-grade materials as well as the 10E200-grade material, as shown in Figure 27.

Excavatability of the Fill Materials. Each of the fill materials was excavated with a backhoe to remove the soil cover and then assessed as to the type of equipment needed to excavate the fill material. The $60 \mathrm{E}$-grade fill developed hardness that prevented excavation with a smooth-edge bucket. The use of a toothed bucket resulted in the material breaking into very large chunks (Figure 28). The field 60E appeared to be a lot harder than that produced in the laboratory. 


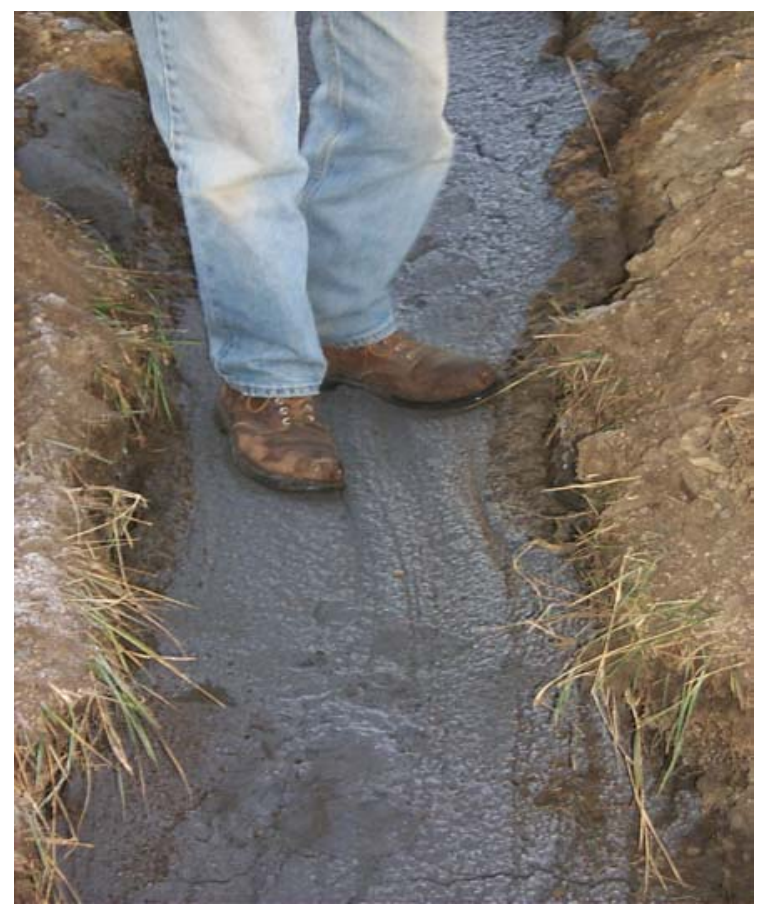

Figure 26. Ability of the 30E-Grade Fill to Support a Person After 16 Hours

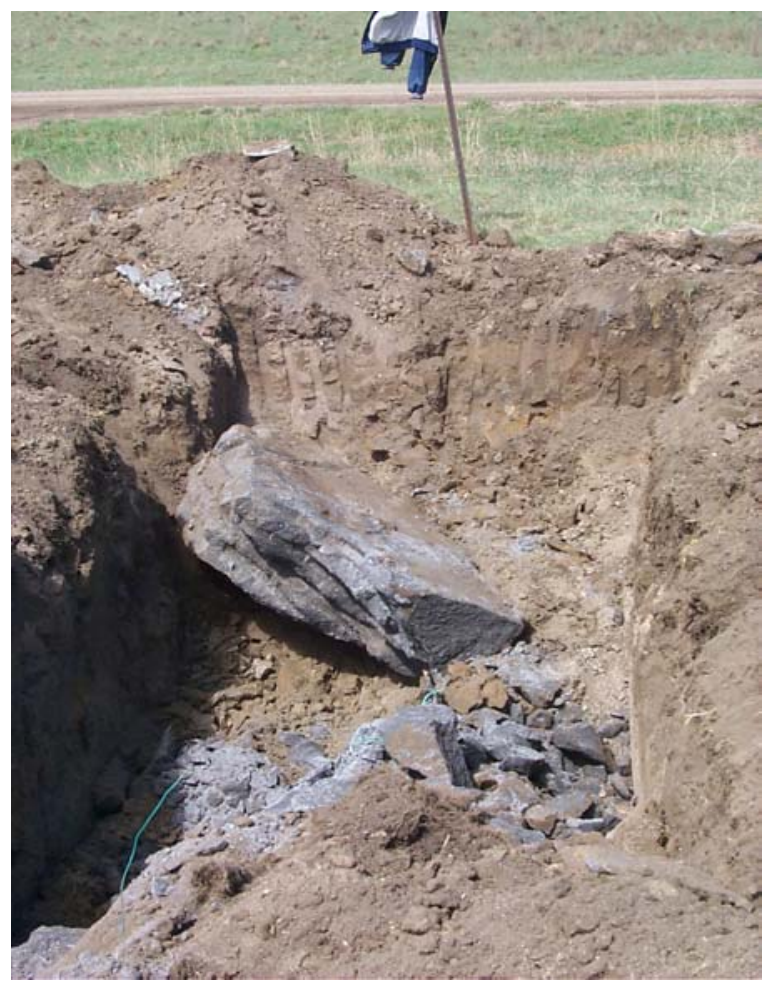

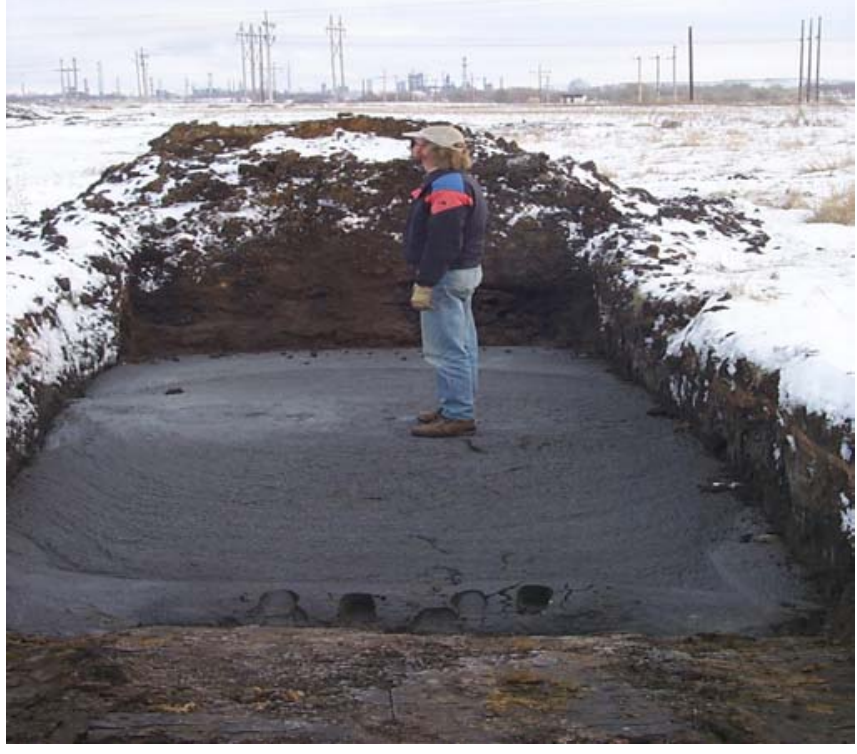

Figure 27. Short-Term Performance of 10E200-Grade Fill After 16 Hours

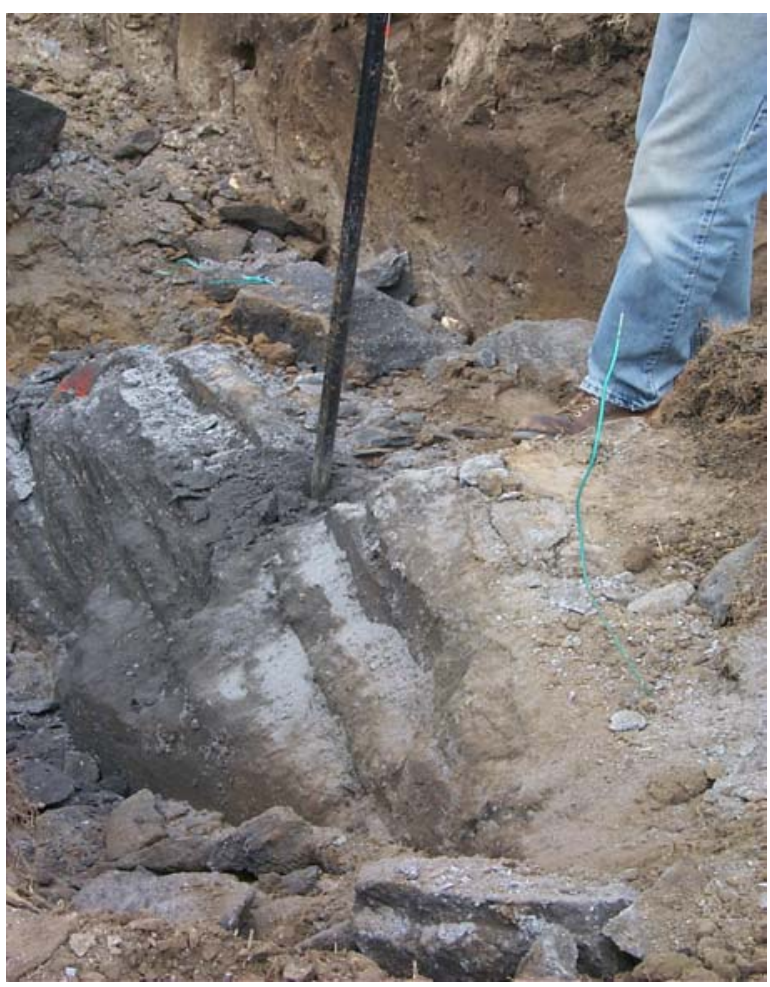

Figure 28. Excavation of the 60E Fill Demonstration 
The smooth bucket had little success with the $30 \mathrm{E}$ mix as well. The toothed bucket was able to cut through the material. (Figures 29 and 30). The 10E200 mix could be excavated with the smooth bucket, the toothed bucket, and with a shovel.

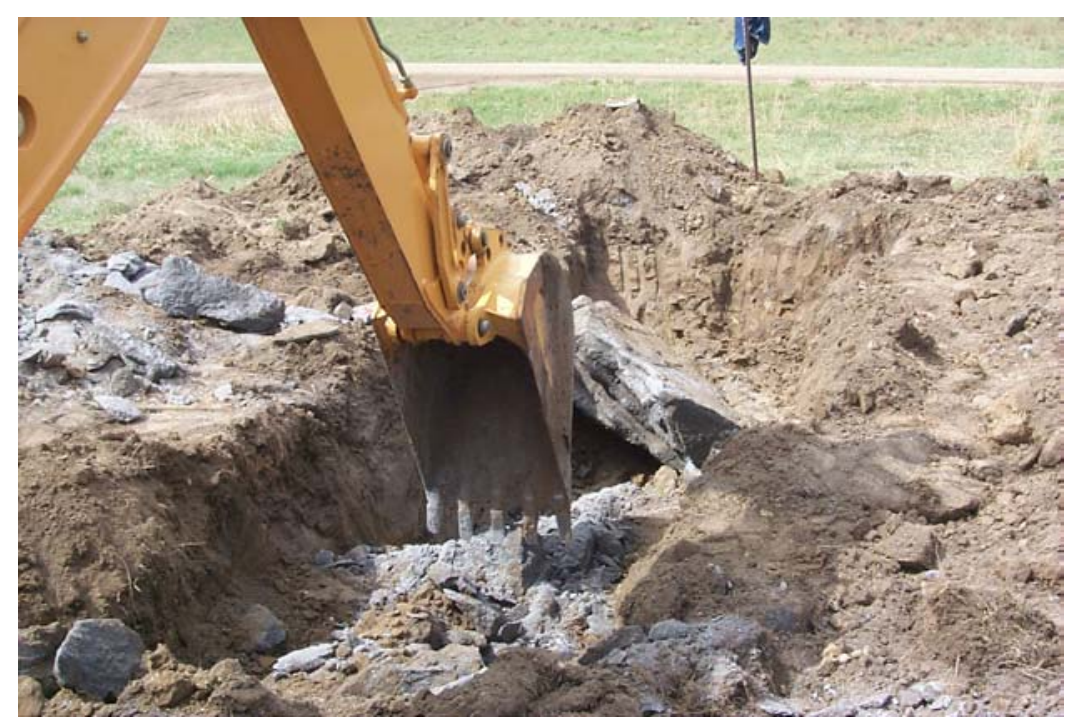

Figure 29. Excavation of the 30E Flowable Fill with a Toothed Bucket Backhoe

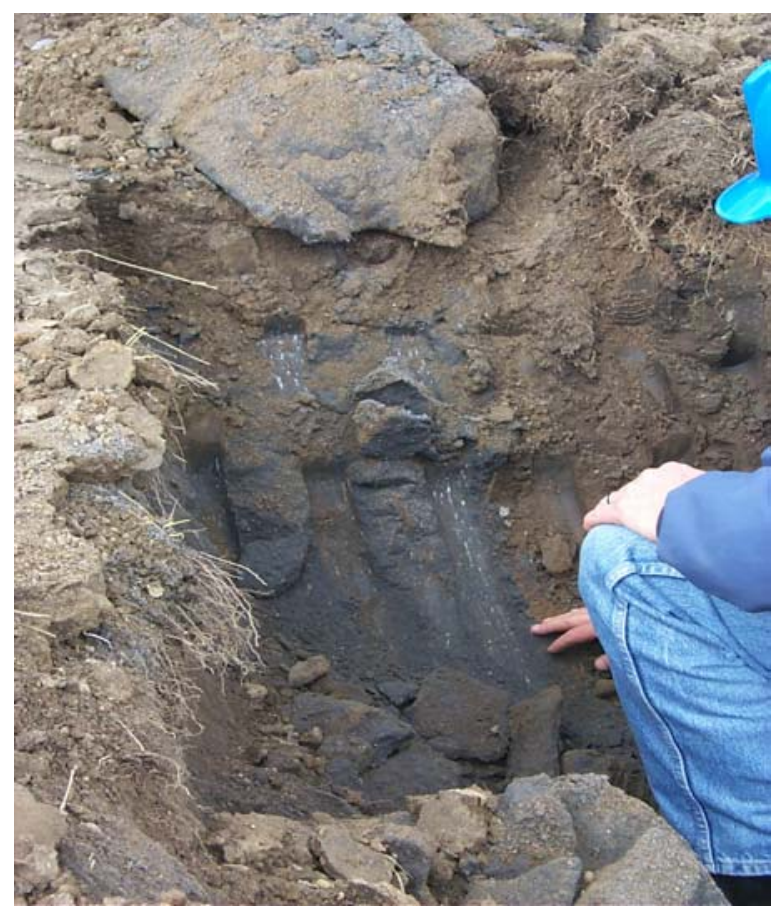

Figure 30. Photograph Showing the Cutting of the 30E Flowable Fill Material with a Toothed Bucket Backhoe 
Geotechnical Properties of the Field Specimens. Samples from each of the excavatable fill demonstrations were collected and returned to WRI for strength testing. Test specimens were produced by sawing the blocks to produce the specimens to the test specimen size. The results of these tests are presented in Table 21.

Table 21. Summary of the Strength of the Excavatable Fills After One Winter Season

\begin{tabular}{|l|c|c|}
\hline MDU Flowable Fill Grade & Age (days) & Strength (psi) \\
\hline 60 E & 211 & 754 \\
30 E & 211 & 374 \\
10E200 & 181 & 33 \\
\hline
\end{tabular}

Impact of Fill on Adjacent Soils. Samples of the soil adjacent to the 60E- and the 30Eflowable fill mixes were collected and analyzed for certain parameters considered indicative of mobility of the fill into the adjacent soils. Two sets of samples were collected; (1) adjacent to two inches, and (2) two inches to 9 inches from the fill. It was noted that the first inch of soil adjacent to the fill seemed to have some stiffness and would hold a ridge when soil was excavated behind it. Each of the samples were analyzed for sodium, calcium, magnesium, sulfates, and the SAR (Sodium Adsorption Ratio) was calculated. The results of the tests are presented in Table 22.

Table 22. Composition of Soils Adjacent to the Fills

\begin{tabular}{|l|c|c|c|c|c|}
\hline Chemical & \multirow{2}{*}{$\begin{array}{c}\text { Prior } \\
\text { Parameter }\end{array}$} & \multicolumn{2}{|c|}{ 60E-Grade Fill } & \multicolumn{2}{|c|}{ 30E-Grade Fill } \\
\cline { 3 - 6 } & To Filling & $0-2$ inches & $2-9$ inches & $0-2$ inches & $2-9$ inches \\
\hline pH & 7.9 & 8.6 & 8.1 & 8.1 & 8.0 \\
Calcium, ppm & 21.7 & 1.0 & 6.1 & 18.7 & 18.6 \\
Magnesium, ppm & 25.5 & 3.7 & 27.8 & 17.4 & 19.6 \\
Sodium, ppm & 36.0 & 41.0 & 22.0 & 118.0 & 85.0 \\
Sulfate, ppm & 4,020 & 2,050 & 2,630 & 6,950 & 5,380 \\
SAR & 7.41 & 26.7 & 12.9 & 27.8 & 19.4 \\
\hline
\end{tabular}

The data indicates that there is some mobility of constituents from the fill into the soil adjacent to the fill. However, the mobility appears consistent with the laboratory-scale field simulator studies described earlier.

Compatibility of Typical Embeds with the Fill Materials. The embed materials, with the exception of the plastic pipe, were recovered from the $30 \mathrm{E}$ and $60 \mathrm{E}$ fills. The fill material adhered to the embeds, but there was no evidence of corrosion and pitting. A photograph of the recovered embed in the flowable fill material is shown in Figure 31. 


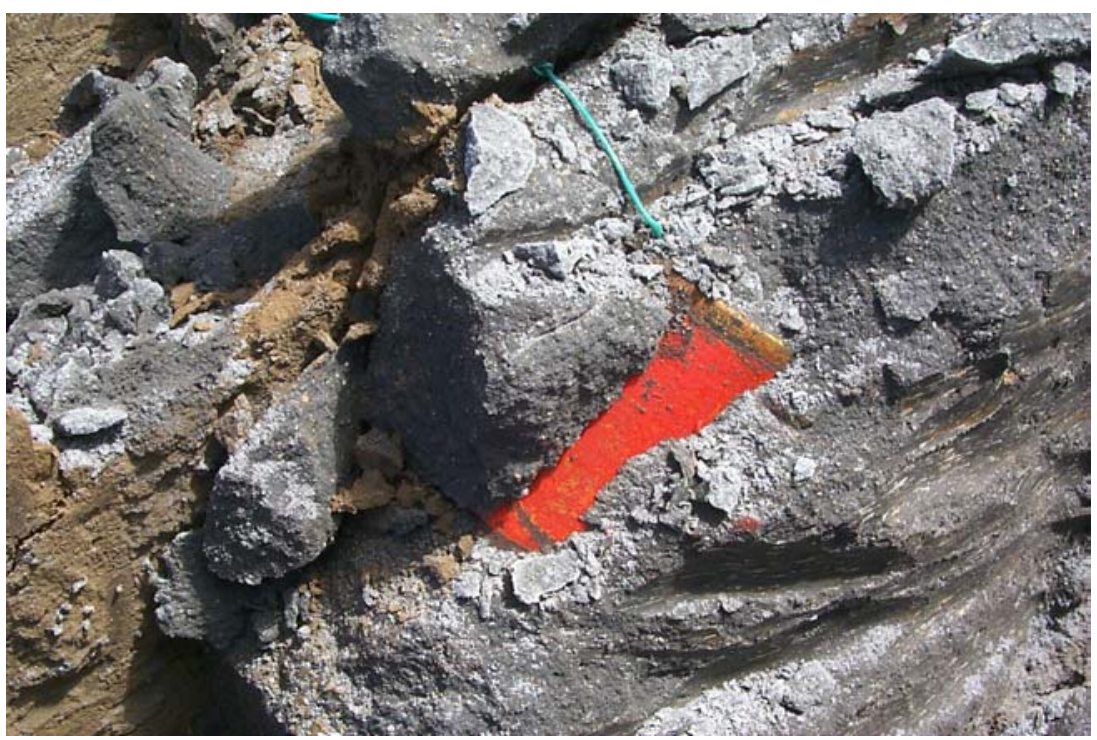

\section{Figure 31. Photograph of Pipe Embed Being Excavated From Flowable Fill}

In summary, the results of the fist testing and demonstration activities proved the following:

- $\quad$ The market assessment indicated that a market exists in the Bismarck-Mandan area for structural construction applications, such as sub-bases for residential and commercial businesses, and excavatable fill applications, such as gas line and utility trench filling.

- $\quad$ The cost of the MDU flowable fill product must be lower than the current $\$ 35-\$ 45 /$ cubic yard price if it is to become a common construction material. Formulations using MDU ash and lower-cost sand alternatives offer that opportunity. An estimated market of 10,000 cubic yards of MDU flowable fill products could be realized if prices could be made competitive.

- $\quad$ The geotechnical properties of the MDU ash-based flowable fill can be modified to meet the needs of a range of applications from structural fill to excavatable fill applications, such as utility trench fill.

- Environmental assessments using standard testing indicate that the environmental properties of the fill materials are compatible with numerous construction applications and do not pose a threat to either adjacent groundwater or soils.

- $\quad$ WRI developed an Environmental Filed Simulator (EFS) method for assessing the impact of flowable fill materials on adjacent soils and found that the zone of impact is less than a couple of inches, thereby posing no threat to adjacent soils.

- Field-scale demonstrations of the MDU flowable fill were constructed and were successful for structural, as well as excavatable applications. Monitoring has 
demonstrated the geotechnical performance, environmental performance, and compatibility with common embed materials of the MDU flowable fill products.

Technical and economic issues were identified in the first testing program that may hinder the commercial acceptance of MDU flowable fill materials, including: (1) the ability to produce a consistent product; (2) the ability to provide a product year round (cold weather retards strength development); and (3) the ability to evaluate and produce commercial quantities of MDU flowable fill using inexpensive materials.

\section{RESULTS OF SECOND TESTING PROGRAM}

WRI and MDU undertook a follow-on study to address the issues identified in the first testing program. The goal of this second testing program was to bring the MDU flowable fill technology to a commercial status, thereby providing a market for a present waste product and in doing so provide jobs and economic growth for the state of North Dakota and lignite-related industries. The specific objectives of the project included: (1) the development of the information necessary to ensure the ability to deliver a consistent flowable fill material to the user and to do so under limited warrantees; (2) verify the economics and performance of MDU flowable fill produced in commercial quantities using alternate materials; and (3) document the performance of MDU flowable fill product through commercial-scale demonstrations and the monitoring of those demonstrations. Through meeting these objectives, the commercial acceptance and deployment of the MDU flowable fill can be realized.

WRI and MDU, in conjunction with the NDIC and the U.S. DOE NETL, have conducted a program of testing and demonstration of the MDU flowable fill product in commercial-scale applications. This testing and commercialization program incorporated the following tasks.

- $\quad$ Task I. Product Variability and Product Service Environment Testing

- $\quad$ Task II. Construction and Operation of MDU Flowable Fill Plant

- Task III. Demonstration and Monitoring of Commercial-Scale Application of MDU Flowable Fill

- $\quad$ Task IV. Project Management and Reporting

It was observed in prior testing that the MDU flowable fill produced under the laboratory-controlled conditions did not have the same geotechnical performance as the MDU flowable fill made at a batch plant for the demonstrations. This is potentially a major obstacle to the commercial acceptance of the MDU flowable fill, since the success of the MDU flowable fill 
is clearly contingent upon the delivery of a consistent product that can be used year round in a range of weather conditions. Unfortunately, due to the logistics of batching of the flowable fill at the Atlas Ready-Mix plant, WRI was unable to use the exact materials for both the laboratory and the demonstrations. This leaves the cause for this difference in geotechnical performance unclear. There are a number of possible causes, including; (1) difference in materials (cement, fly ash, sand, or water), and (2) differences in the temperature regimes of the curing of the materials. Each of these parameters could be responsible, and it is therefore imperative to understand the effect of each on the geotechnical properties of the MDU flowable fill product. As such, testing was conducted to examine the effect of MDU ash variability and curing environment on the geotechnical properties of the resultant flowable fill product.

One of the deficiencies in the prior demonstration activities was the fact that the logistics at the Atlas Ready Mix plant prevented the incorporation of low-cost alternative materials such as sand in the demonstration mixes. Instead, WRI was forced to use the standard concrete sand available at the Atlas Ready-Mix plant. It is known that alternate sand materials not only can influence the geotechnical properties of the flowable fill, but they also represent a major cost savings.

The present commercial ready-mix concrete plants in the Bismarck-Mandan area were not able to modify their facilities to produce sufficient flowable fill quantities using alternate materials. A commercial-scale batch plant was constructed on MDU property centrally located to each of the three ready-mix concrete companies. The facility was capable of batching flowable fill with a range of properties using a range of alternate materials. MDU personnel operated the facility. Any and all three of the local ready-mix concrete companies would have access to the MDU flowable fill batch plant, and it was intended that their trucks and drivers would be used for hauling the flowable fill to potential commercial demonstration sites.

The purpose of the project was to use different MDU flowable fill grades and formulations in commercial-scale demonstrations and to monitor the geotechnical performance in order to assess the costs of these flowable fill mixes.

A series of demonstrations was to be conducted. The proposed demonstrations would be of sufficient size to use conventional trucking and emplacement equipment. The demonstrations would be selected following extensive assessment of the types of markets that the MDU flowable fill could penetrate. MDU and WRI personnel would interact with potential users, such as the city of Bismarck and Mandan, the MDU gas distribution division, and local residential and commercial contractors. Based on these contacts, three to five commercial-scale demonstrations would be conducted. This task would also involve documentation and monitoring of the commercial-scale applications resulting from the MDU flowable fill produced from the MDU batch plant constructed under Task II.

\section{Results of Task 1 - Product Variability and Product Service Environment Testing}


Testing was conducted at WRI to examine the effect of MDU Heskett ash variability and the MDU flowable fill curing environment on the geotechnical properties of the MDU flowable fill materials. Different fly ash samples from the Heskett plant were to be taken over an extended period, including the ash used in the demonstrations of 1998 (Steen and Bland, 2001). The cement used was a Type I/II Portland cement from Mountain Cement in Laramie, Wyoming, and a Type I/II Portland cement from LaFarge Cement in North Dakota. These cements represent the cements used in earlier laboratory testing (Steen and Bland, 2001) and in the demonstration activities of 1998.

The testing plan included chemical analyses of the fly ash to be performed to ascertain what changes in composition occur with time. Strength and set time specimens were prepared with these different sand, cement, and ash materials, and strength tested for up to one year. The curing environment, specifically the effect of temperature on the geotechnical properties, was examined. The strength and set time specimens were cured at $73^{\circ} \mathrm{F}\left(23^{\circ} \mathrm{C}\right)$ and at $40^{\circ} \mathrm{F}\left(7^{\circ} \mathrm{C}\right)$.

\section{Evaluation of the Variability of the MDU Heskett Ash}

Testing of the variability of the MDU ash and the assessment of its effect on the performance of the Ready-Fill was completed. Previous testing has indicated that the performance of the flowable fill material was dependent on the ash characteristics and the curing conditions. Over a two-year period samples of the fly ash from the Heskett Station were collected and analyzed for chemical composition. The results of the testing are presented in Table 23.

The data represent the composition of the ashes collected on four separate occasions. The 'ReStart' ash represents the ash immediately following an annual scheduled shutdown and associated maintenance of the plant. The chemistry of the ashes is quite similar with the exception of a variance in the sodium content of the ash from a high of $5.26 \%$ to a low of $2.25 \%$. This reflects the burning of a number of different coals at the Heskett Station.

Evaluation of the Variability of the MDU Flowable Fill

The MDU ashes described above were used in the fabrication of MDU flowable fill test specimens. The fabricated MDU flowable fill specimens were tested for set time characteristics and strength development under $72-^{\circ} \mathrm{F}\left(22.2-^{\circ} \mathrm{C}\right)$ and $40-{ }^{\circ} \mathrm{F}\left(7-{ }^{\circ} \mathrm{C}\right)$ curing conditions.

Table 23. Summary of the Composition of Heskett Ashes Taken Over Several Years

\begin{tabular}{|l|c|c|c|c|c|}
\hline Component, wt \% & '95 Ash & NDDH Ash & Demo '98 Ash & $\begin{array}{c}\text { ReStart Nov'99 } \\
\text { Ash }\end{array}$ & April '99 Ash \\
\hline $\mathbf{S i O}_{2}$ & 30.63 & 28.94 & 24.42 & 20.18 & 23.58 \\
$\mathbf{T i O}_{2}$ & 0.33 & 0.38 & 0.35 & 0.35 & 0.35
\end{tabular}




\begin{tabular}{|l|c|c|c|c|c|}
$\mathrm{Al}_{\mathbf{2}} \mathbf{O}_{3}$ & 9.97 & 8.03 & 10.83 & 10.82 & 10.74 \\
$\mathbf{F e 2 O 3}$ & 3.67 & 4.49 & 7.72 & 6.88 & 9.28 \\
$\mathbf{C a O}$ & 21.13 & 23.77 & 26.50 & 28.17 & 30.11 \\
$\mathbf{M g O}$ & 6.92 & 7.56 & 9.10 & 9.66 & 9.86 \\
$\mathbf{K}_{\mathbf{2}} \mathbf{O}$ & 0.73 & 0.63 & 0.41 & 0.40 & 0.54 \\
$\mathbf{N a}_{\mathbf{2}} \mathbf{O}$ & $\mathbf{3 . 9 5}$ & $\mathbf{3 . 7 4}$ & $\mathbf{4 . 7 4}$ & $\mathbf{5 . 2 6}$ & $\mathbf{2 . 2 5}$ \\
$\mathbf{P}_{\mathbf{2}} \mathbf{O}_{\mathbf{5}}$ & 0.49 & 0.60 & 0.57 & 0.59 & 0.55 \\
$\mathbf{S O}_{3}$ & 11.69 & 10.48 & 13.85 & 16.12 & 11.28 \\
$\mathbf{M n O}$ & 0.12 & 0.15 & 0.14 & 0.12 & 0.16 \\
$\mathbf{S r O}$ & 0.39 & 0.39 & 0.58 & 0.64 & 0.57 \\
$\mathbf{B a O}$ & 0.45 & 0.57 & 0.79 & 0.81 & 0.73 \\
Total & 90.68 & 100.0 & 100.00 & 100.00 & 100.00 \\
\hline
\end{tabular}

Based on oxides normalized to a moisture-free basis.

The effect of sand type used in the MDU flowable fill on geotechnical properties is summarized in Figure 32. The Atlas sand is a material that meets ASTM specifications as a concrete sand. The off-spec fine sand is produced as part of the preparation of sized sand for the Heskett Station circulating fluidized-bed combustor. The off-spec sand is much finer than the Atlas concrete sand. The off-spec fine sand will be used in the commercial MDU flowable fill operation. The results indicate that the Atlas Ready Mix concrete sand requires less water in order to achieve the same flow and excess water in turn retarded the set times and early strength development of the Fischer Sand and Gravel fine sand mixes.

A comparison of the strength development of the cement used in the laboratory testing (Wyoming Cement) and that used in the demonstration activities (North Dakota Cement) is presented in Figure 33. The cement used in the laboratory tests did not result in as high a strength development as the cement from the North Dakota supplier.

The temperature of curing had a large effect on the set times and early strength development, as one would expect. The set times and unconfined compressive strength data for warm and cold temperature curing are presented in Table 24 . The cold temperature $\left(40{ }^{\circ} \mathrm{F}\right)$ cured MDU flowable fill product took longer to achieve initial set than the warm-cured flowable fill. The strength development was also retarded by the cold temperature of curing, but recovered at later ages to be similar in strength after one year. 


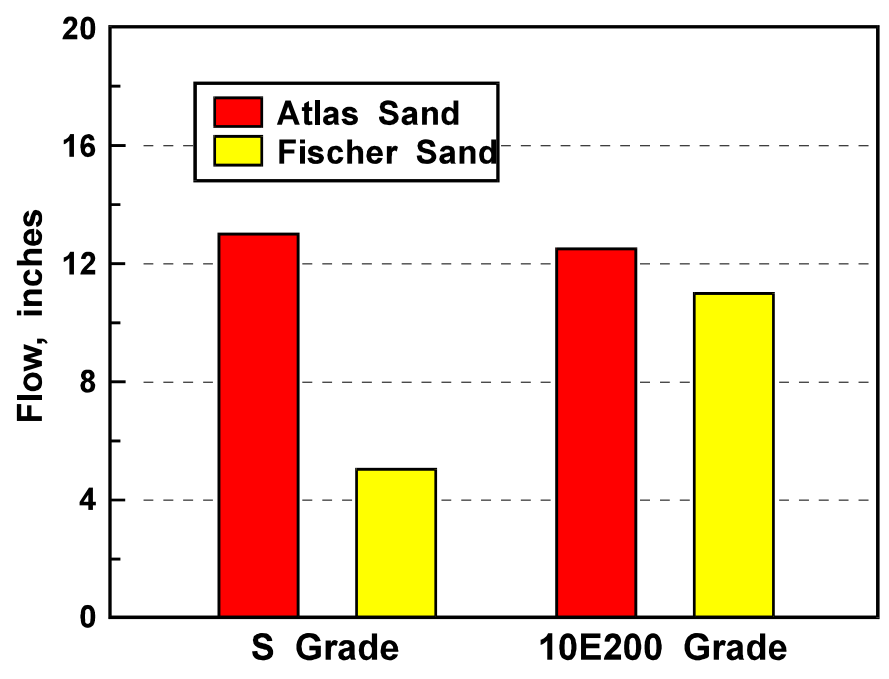

Figure 32. Comparison of Water Demand for MDU Flowable Fill due to Difference in Sand Characteristics

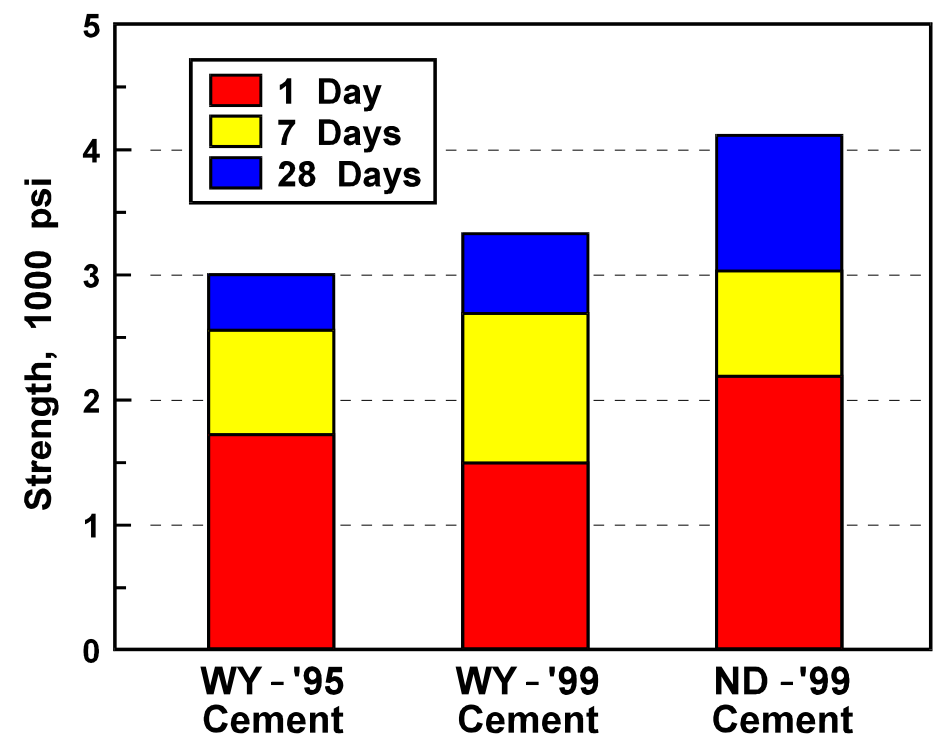

Figure 33. Strength Characteristics of Cements Used in Study

Table 24. Curing Temperature Effect on Geotechnical Properties of Laboratory-Cured MDU Flowable Fill Specimens 


\begin{tabular}{|c|c|c|c|c|}
\hline \multirow{2}{*}{$\begin{array}{l}\text { MDU Flowable Fill Grade } \\
\text { Curing Temperature, }{ }^{\circ} \mathbf{F}\end{array}$} & \multicolumn{2}{|c|}{ S Grade } & \multicolumn{2}{|c|}{ E Grade } \\
\hline & $72^{\circ} \mathrm{F}$ & $40^{\circ} \mathrm{F}$ & $72^{\circ} \mathrm{F}$ & $40^{\circ} \mathrm{F}$ \\
\hline \multicolumn{5}{|c|}{ Set Time, penetration resistance, psi } \\
\hline 8 hours & 14 & 0 & na & na \\
\hline 24 hours & 256 & 21 & 54 & 3 \\
\hline 48 hours & 736 & 128 & 212 & 26 \\
\hline 72 hours & 1,632 & 192 & 360 & 24 \\
\hline \multicolumn{5}{|c|}{ Unconfined Compressive Strength, psi } \\
\hline 7 days & 182 & 35 & 31 & ts \\
\hline 24 days & 502 & 93 & 34 & 28 \\
\hline 90 days & 638 & 408 & 72 & 37 \\
\hline 180 days & 773 & 495 & 82 & 36 \\
\hline 365 days & 839 & 635 & 62 & 50 \\
\hline
\end{tabular}

The ash variability did not have a significant effect on the set times and strength development of the MDU flowable fill product.

In summary, the MDU flowable fill geotechnical properties were shown to vary with sand characteristics, ash characteristics, and even cement sources. However, a consistent product can be produced and supplied to a contractor.

Temperature affected the strength development of the curing flowable fill product. Cold curing conditions resulted in retarded set development and unconfined compressive strength. However, the flowable fill mixtures containing the MDU fly ash will generate heat during early hydration and curing, resulting in moderated temperatures of pours of sufficient size to avoid rapid heat loss in the field. The use of hot water in the winter and its heat generation will allow for its use during cold winter months, although some delay in strength development will occur. The limitations on the placement of the MDU flowable fill product under cold conditions will be similar to that of other concrete products.

\section{Results of Task 2 - Construction of the Ready-Fill Batch Plant}

The commercial ready-mix concrete plants in the Bismarck-Mandan area were not able to modify their facilities to produce sufficient quantities of flowable fill product using alternate materials such as MDU ash and waste sand. It was therefore proposed that a batch plant be constructed capable of using such alternate materials. In addition, the plant needed to be capable of producing truck quantities sufficient for assessing the flowable fill product characteristics in commercial-scale applications.

A used batch plant was acquired and refurbished. The plant consisted of a sand weigh hopper for sand, a belt conveyor for sand conveyance to the truck load out, a fly ash hopper that was modified to include a fabric filter, a fly ash auger to transfer ash to a weigh hopper, and a fly ash auger to transfer the weighed ash from the ash weigh hopper to the truck. Photographs of the 
components of the batch plant are presented in Figure 34 through 37 . In addition, an office trailer for the facility and a front-end loader were acquired.

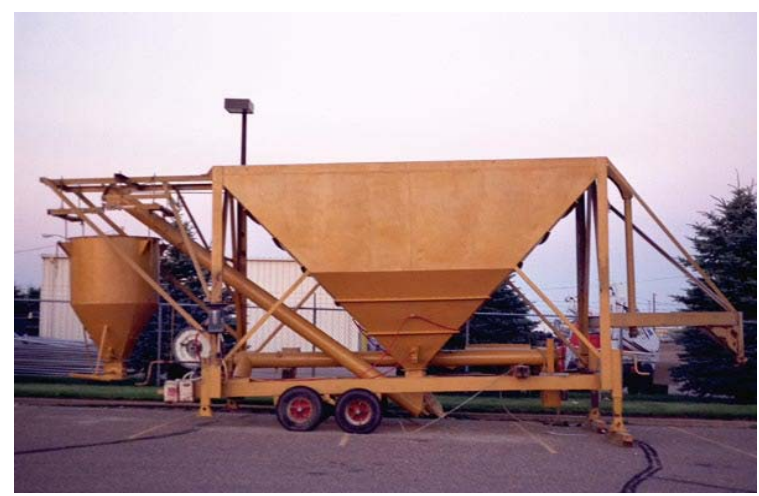

Figure 34. Ash Hopper with Weigh Hopper

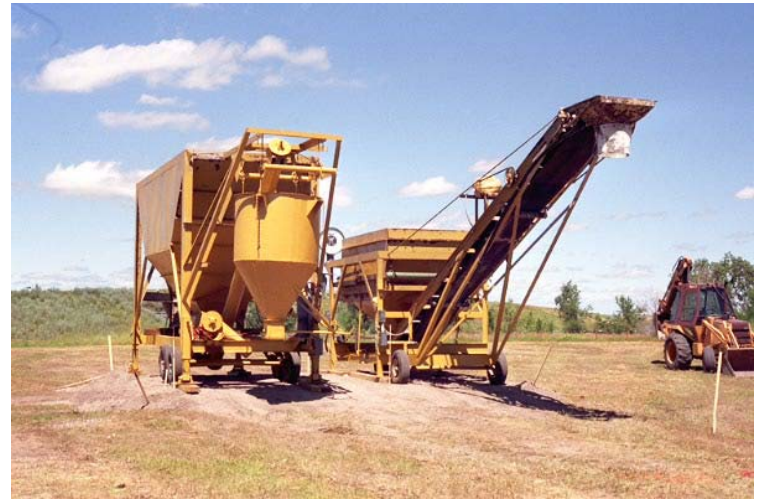

Figure 36. Placement of the Sand Hopper (Right) and Ash Hopper (Left)

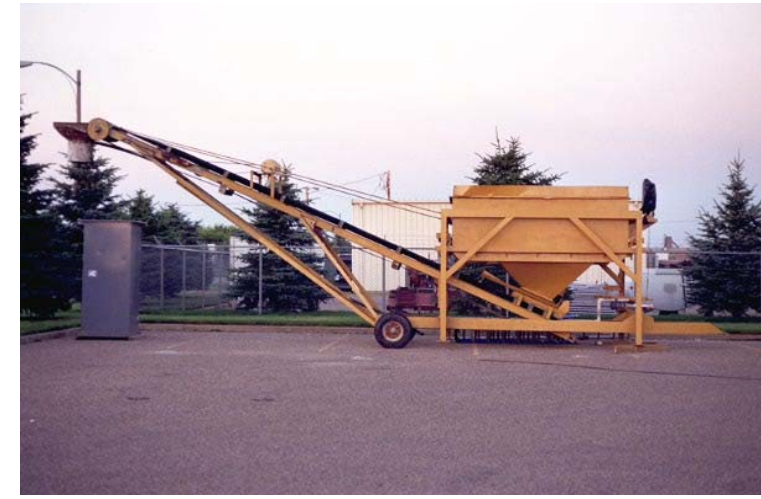

Figure 35. Sand Hopper with Conveyor Belt

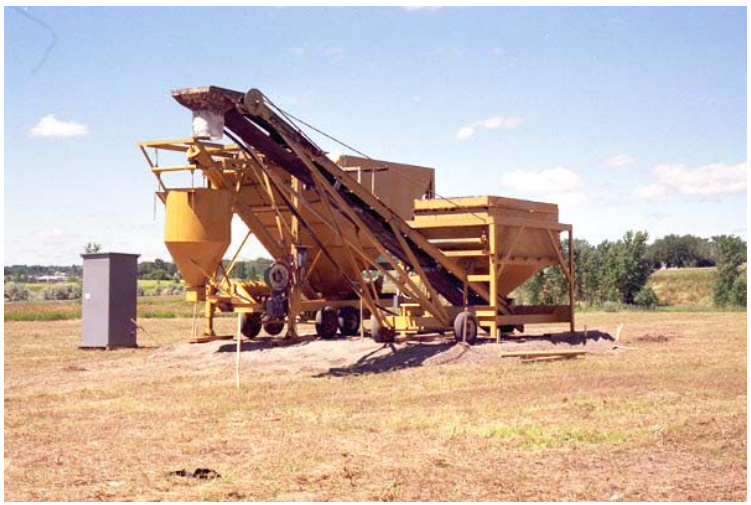

Figure 37. Placement of the Batch Plant at Site

The site for the batch plant was leased and located centrally between Dakota Ready-Mix and Atlas Ready-Mix. The site was prepared and the batch plant assembled and constructed on the site in the summer of 1999. A photograph of the completed batch plant is presented in Figure 38. 


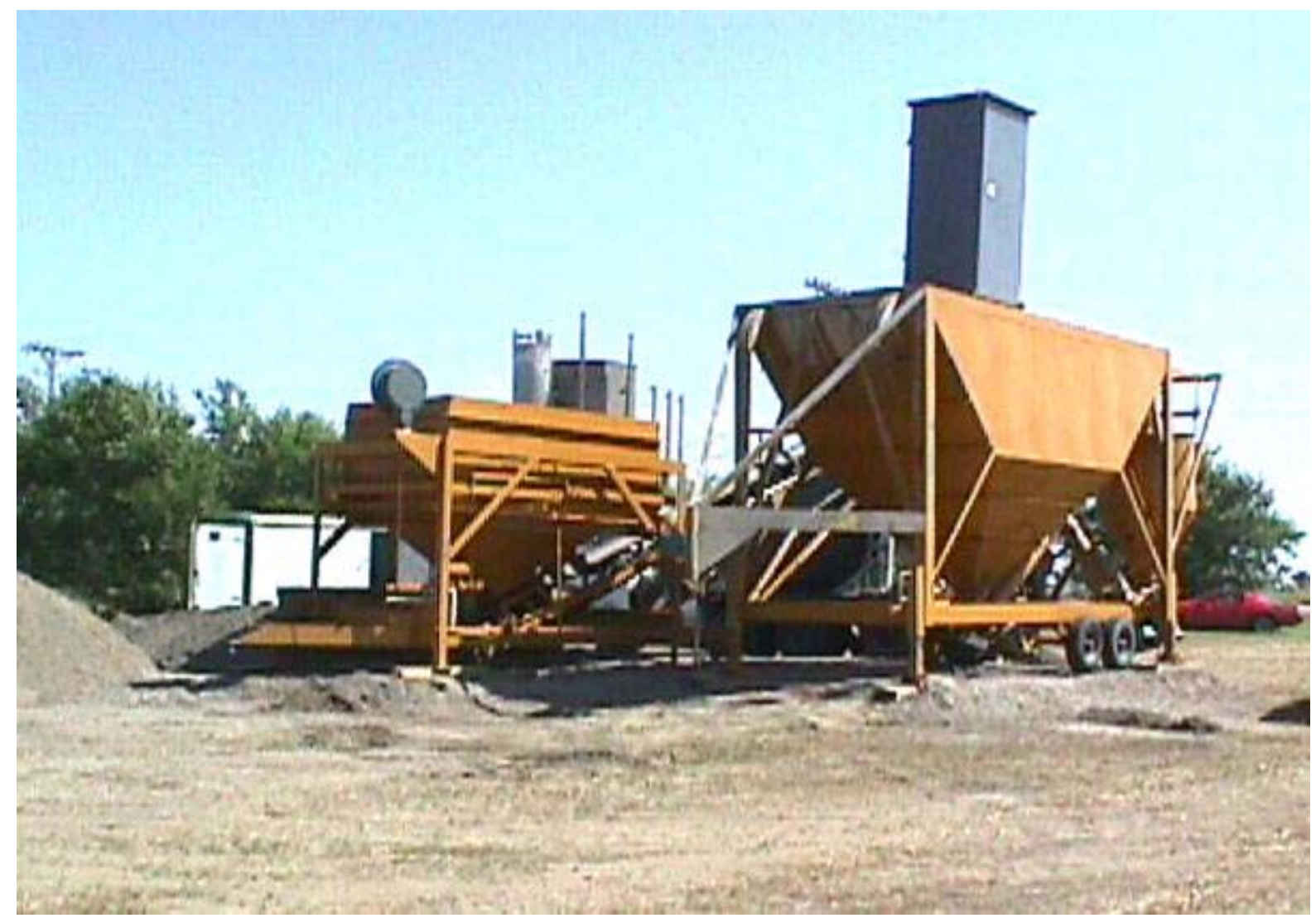

Figure 38. Assembled Ready-Fill Batch Plant in Bismarck, North Dakota

The ash was transported from the Heskett plant by cement tanker and pneumatically delivered into the ash hopper. The sand was delivered to the site by truck and stockpiled on site. Delivery of the sand to the sand hopper was accomplished with a front-end loader. The batch plant was in operation by the end of July 1999 and was capable of producing truck-load quantities of flowable fill material for the demonstration activities.

The flowable fill product using sand, MDU ash, cement, and water was trademarked as Ready-Fill and the batch plant operated under that name for both this project and future commercial activities. Ready-Fill is a product that is custom designed for the application. However, earlier developments have shown the product can be generally produced as E-grade and S-grade materials. Their general mix proportions and performance properties are presented in Table 25 . 
Table 25. Comparison of the Mix Proportions of the MDU Flowable Fill Materials and Medium- and Low-Strength Concrete

\begin{tabular}{|l|ccc|cc|}
\hline & \multicolumn{3}{|c|}{ MDU Flowable Fill Material } & \multicolumn{2}{c|}{ Portland Cement Concrete } \\
\cline { 2 - 5 } & E Grade & S Grade & S Grade & Low Strength $^{\mathbf{1}}$ & Medium Strength $^{\mathbf{1}}$ \\
\hline Mix Components & & & & & \\
Heskett Ash (pcy) & 200 & 350 & 350 & & 600 \\
Portland Cement (pcy) & 10 & 60 & 150 & 430 & 1,430 \\
Fine Aggregate (pcy) & 2,750 & 2,750 & 2,750 & 1,350 & 1,740 \\
Coarse Aggregate (pcy) & 550 & 565 & 570 & 300 & 300 \\
Water (pcy) & & & & & 4,520 \\
Properties & $<80$ & $<200$ & $>1,000$ & 2,650 & 135 \\
$\begin{array}{l}\text { Strength @ 28 days } \\
\text { (psi) }\end{array}$ & 120 & 123 & 125 & 130 & \\
Unit Weight (pcf) & & & & & \\
\hline
\end{tabular}

${ }^{1}$ Reference: Concrete, Structure, Properties and Materials (Mehta, 1986)

The facility was capable of batching a Ready-Fill product with a range of properties using fine off-spec sand and MDU ash. The sand was supplied by Fischer Sand and Gravel, the ash supplied by MDU, and the cement and water was supplied by either Dakota Ready Mix or Atlas Ready Mix. The facility was operated by MDU personnel. Any and all three of the local ready-mix concrete companies would have access to the Ready-Fill batch plant, and their trucks and drivers would be used for hauling the Ready-Fill product to the commercial-scale demonstration sites described in Task III.

\section{Results of Task 3 - Commercial-Scale Field Demonstrations of the Ready-Fill Product}

One of the main purposes of the project was to use different Ready-Fill grades and formulations in commercial-scale demonstrations and to monitor the geotechnical performance in order to assess the costs of these Ready-Fill products. The demonstrations would be of sufficient size to use conventional trucking and emplacement equipment. The demonstrations would be selected following extensive assessment of the types of markets that the Ready-Fill product could penetrate. MDU and WRI personnel contacted potential users, such as the city of Bismarck and Mandan, the MDU gas distribution division, and local residential and commercial contractors to define applications for the Ready-Fill product and to design appropriate demonstrations. Based on these contacts, six commercial-scale demonstrations were defined, constructed, and documented.

These demonstrations centered on three general applications for Ready-Fill, specifically excavatable, structural, and niche applications. 


\section{- $\quad$ Ready-Fill Excavatable Applications}

Demonstration at the Ready-Fill Batch Plant

Utility Trench Backfill for Residential Subdivision Development

Fill Material Main Street Repair Project for the City of Bismarck

\section{- $\quad$ Ready-Fill Structural Applications}

Base Material for Coal Rail Car Unloading Facility at Heskett Station

Storm Water Drainage Ditch Construction at Krider Equipment

\section{- $\quad$ Ready-Fill Niche Applications}

Repair of MDU Sweet Avenue Substation Retaining Wall Erosion

Base Material for Residential Brick Patio Construction

For each of the demonstrations, the Ready-Fill product was batched at the Ready-Fill facility constructed under Task II and the product delivered by either Dakota Ready-Mix or Atlas Ready Mix. Photographs in Figure 39 show the batching and loadout of Ready-Fill for these commercial-scale demonstrations. A summary of each of the demonstrations is provided below.

\section{$\underline{\text { Ready-Fill Excavatable Applications }}$}

Commercial-scale deployment of the Ready-Fill E-grade product was demonstrated at several sites. A small demonstration site that was available for monitoring was poured at the Ready-Fill batch plant site in Bismarck, North Dakota. Approximately 8 cubic yards of E-grade Ready-fill was poured in an area excavated for the demonstration. Figure 40 shows the consistency of the pour at the site. The E-grade Ready-Fill was allowed to cure overnight and had developed strength sufficient to support pick-up traffic the next day (Figure 41). The site was used to show prospective contractors, users, and regulatory personnel the characteristics of the material, including the excavatability of the material. The cured product could be excavated with a shovel.

A second application of the Ready-Fill E-grade product was at a local residential development where the product was used in a classical trench-filling application. Utility line trenches at the residential site were excavated so that they would underlay the streets of the subdivision. Figures 42 and 43 show the excavation of the utility lines and the placement of the Ready-Fill product for the utility trench-filling application.

For this application, the Ready-Fill material had been covered as part of the project, therefore visual and geotechnical monitoring of the performance of the placed Ready-Fill was not possible. However, contractors were pleased with its handling and placement. 

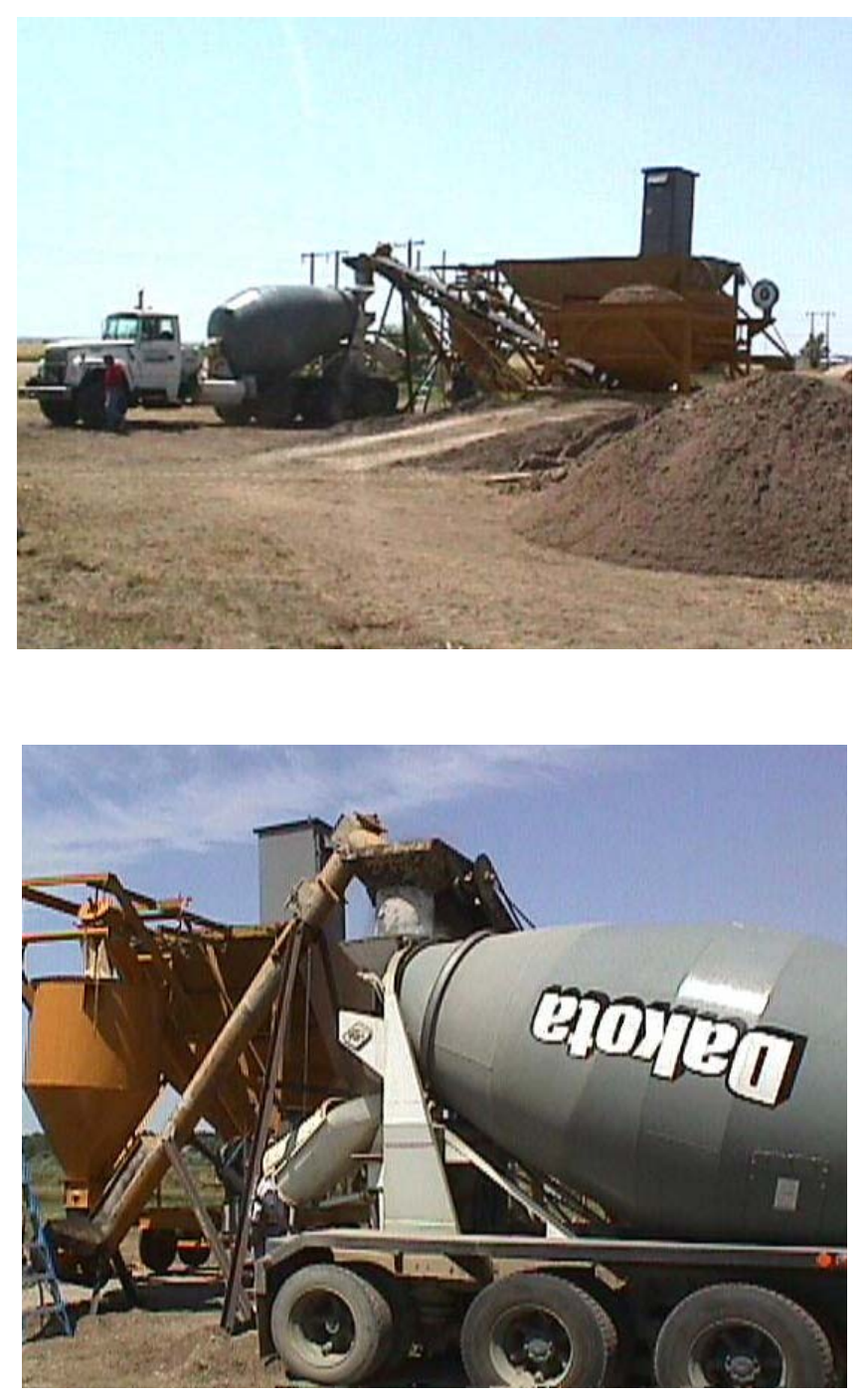

Figure 39. Photographs of the Batching and Loadout of the Ready-Fill Product 


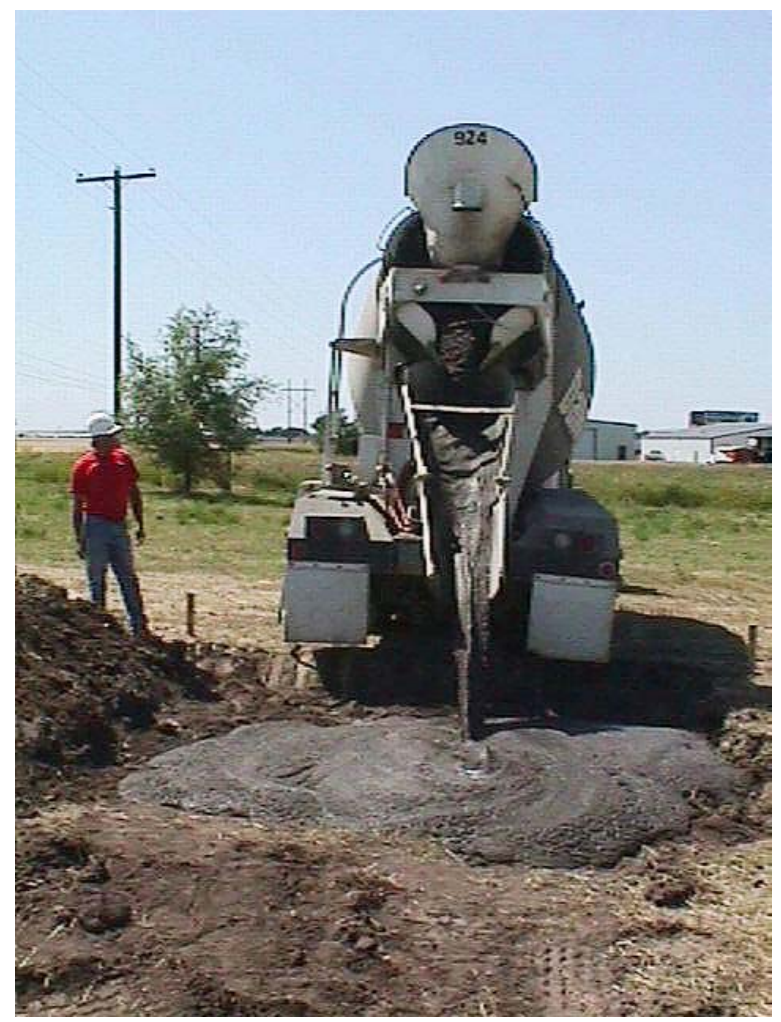

Figure 40. E-Grade Ready Fill Product Being Placed at Demonstration Site

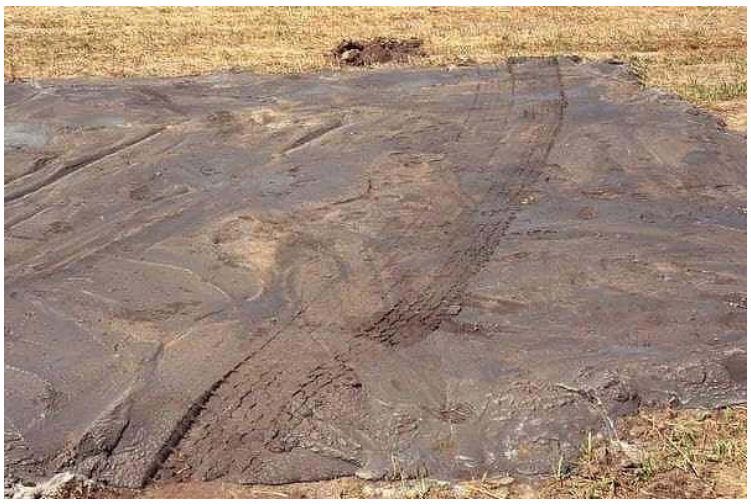

Figure 41. Pick-Up Truck Tire Track Indentation on Excavatable-Grade Ready-Fill After 24 Hours 


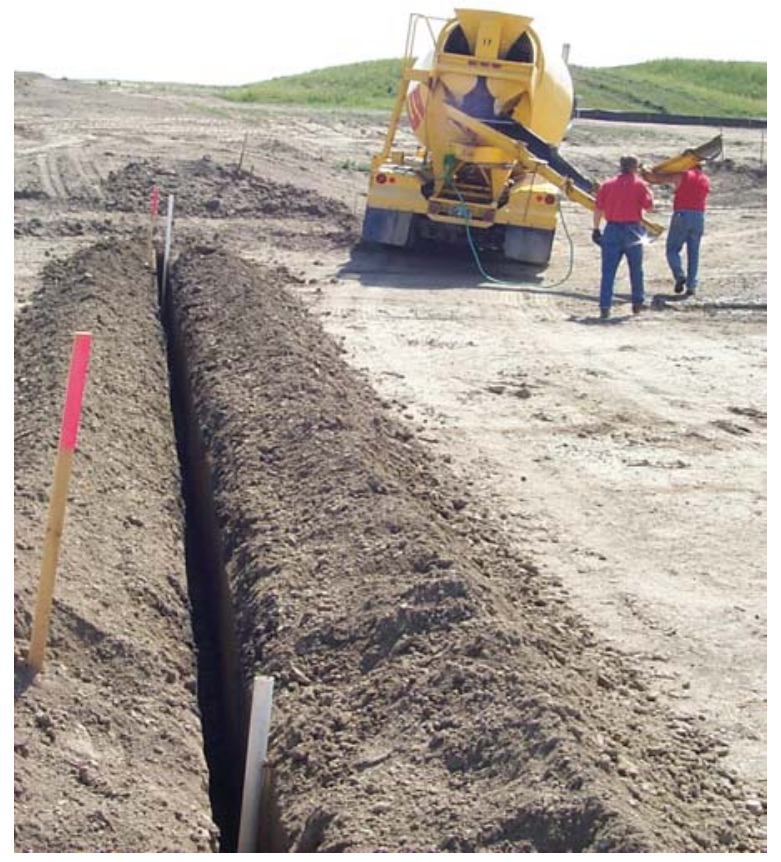

Figure 42. Excavated Utility Trench for Subdivision Development

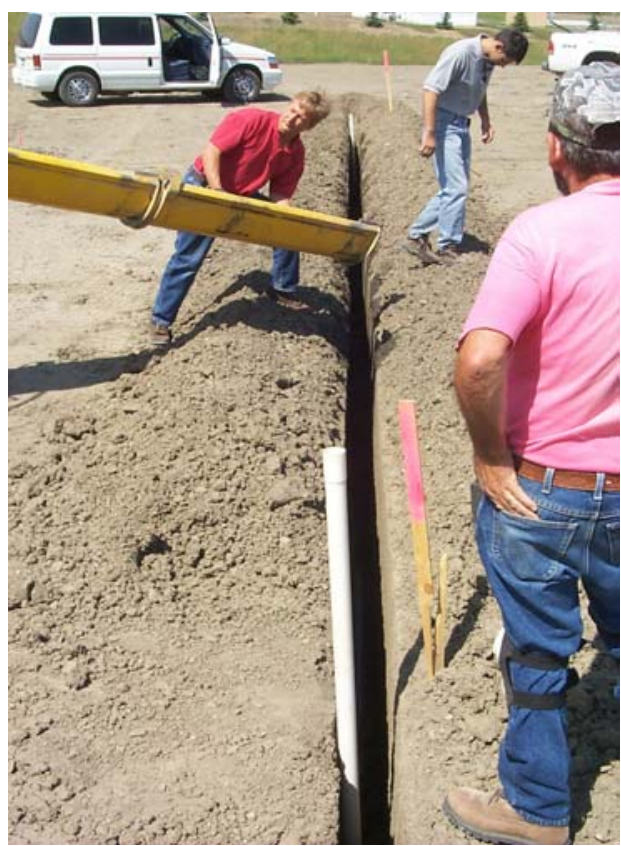

Figure 43. Placement of Ready-Fill for Utility Trench Fill 
A third commercial-scale demonstration of the Ready-Fill E-grade product was a recent Main Street repair by the city of Bismarck. Ready-Fill was used for trench and backfilling applications in that construction project. Approximately 16 cubic yards of E-grade Ready-Fill product were batched, delivered, and placed as part of the Main Street construction project (Figure 44).
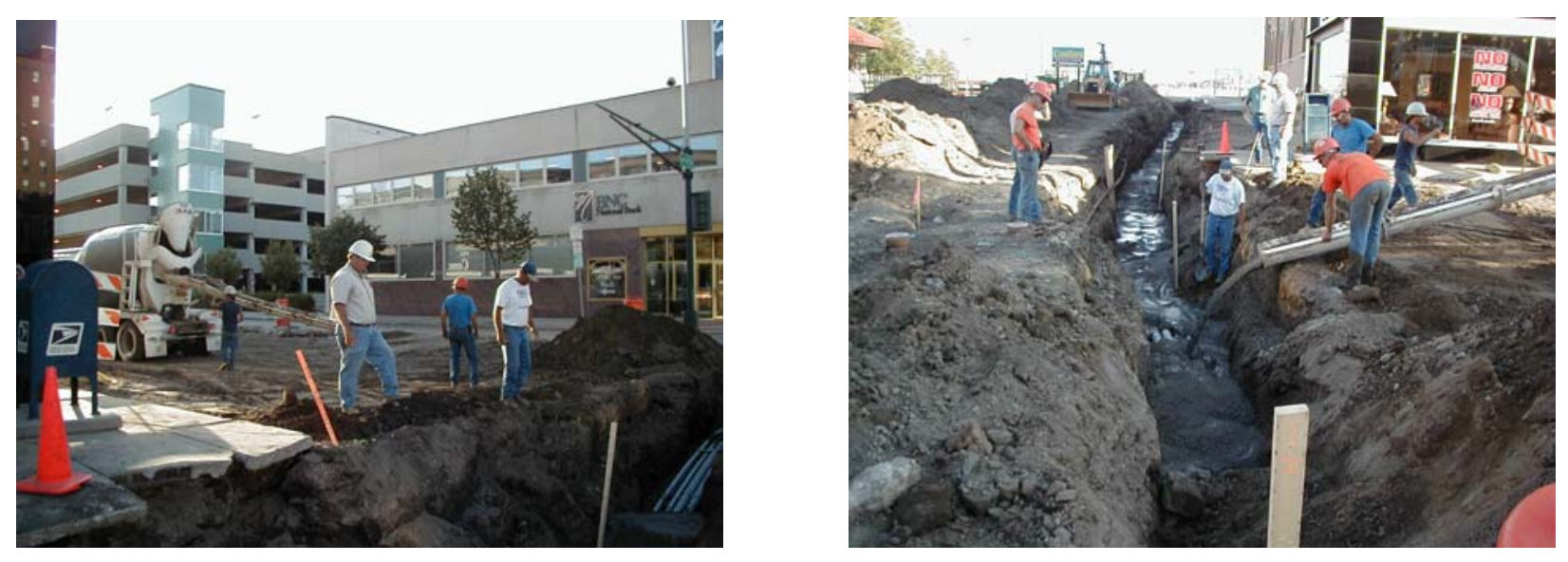

\section{Figure 44. Photographs Showing the Placement of Ready-Fill as Part of the Main Street Repair Project in Bismarck, North Dakota}

For this application, the Ready-Fill material had been covered as part of the project, therefore visual and geotechnical monitoring of the performance was not possible, but contractors were pleased with its handling and placement.

\section{$\underline{\text { Ready-Fill Structural Applications }}$}

The S-grade Ready-Fill product was demonstrated in a number of applications in the Bismarck, North Dakota area. Two of these applications include: (1) the use of the Ready-Fill product as a sub-base for front-end loader traffic associated with coal unloading facilities at the MDU Heskett Station in Mandan, North Dakota; and (2) the use of S-grade Ready-Fill for the construction of storm water drainage at a local equipment sales and rental facility in Bismarck, North Dakota.

The MDU Heskett demonstration was an extension of the earlier demonstration of the MDU structural-grade flowable fill product. In that demonstration approximately 48 cubic yards of S-grade Ready-Fill product was poured at the Montana-Dakota Heskett Station in Mandan as a base material for the construction of a work surface for front-end loader operation associated with the coal rail car unloading facility (Figure 45). A concrete work area was constructed over part of the flowable fill area. Front-end loaders are used to push rail cars into position and have operated over both the flowable fill base and the concrete work area for over three years without any deterioration of the base material. 


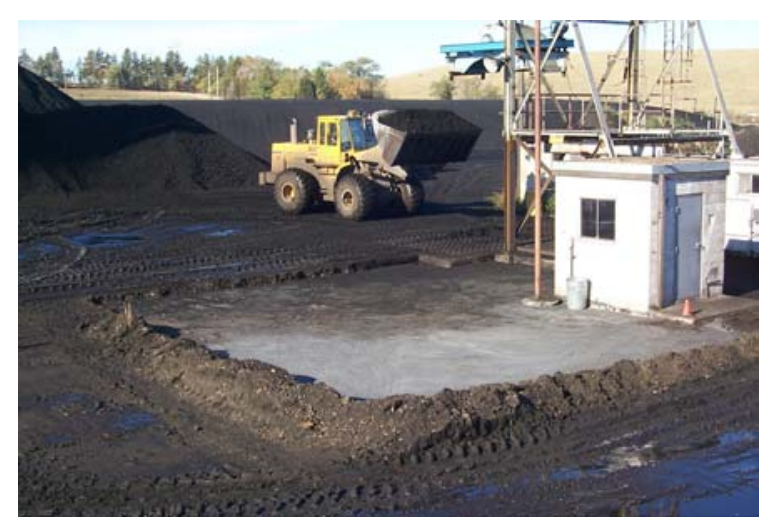

\section{Figure 45. Final Product Showing Front-End Loader Service}

The results of that earlier work were so well received by the workers at the coal rail car unloading facilities that an additional commercial-scale demonstration was conducted on the other side of the rail tracks where front-end loaders dump coal from stockpiles into the railloading hopper. The area is very soft and front-end loader traffic sinks into the soil and causes poor tire traction and overall increased fuel usage. Approximately 24 cubic yards of S-grade Ready-Fill were batched and placed in the excavated areas of front-end loader traffic (Figure 46).
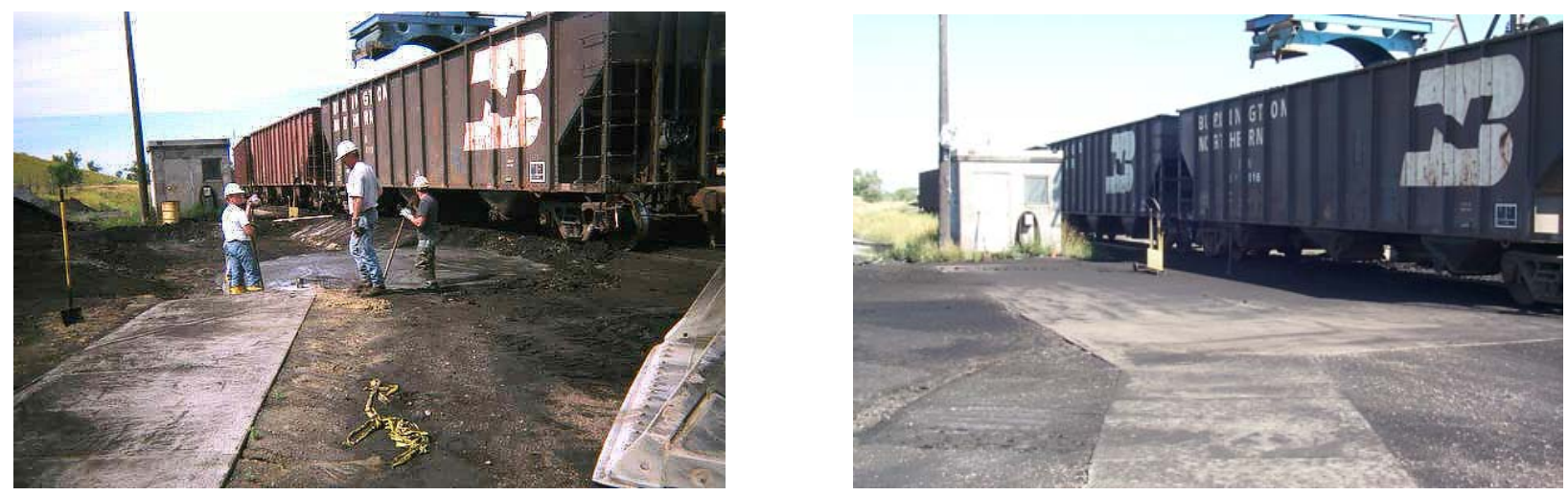

Figure 46. Photographs Showing the Location of the Ready-Fill Being Placed and the Final Work Area at the Heskett Station Second Demonstration

Both sites have been revisited on several occasions to determine how the Ready-Fill product is performing (Figure 47). Strengths in excess of 1,000 psi have been determined for the product used at the sites and there is no visual evidence of deterioration of the product in service. 


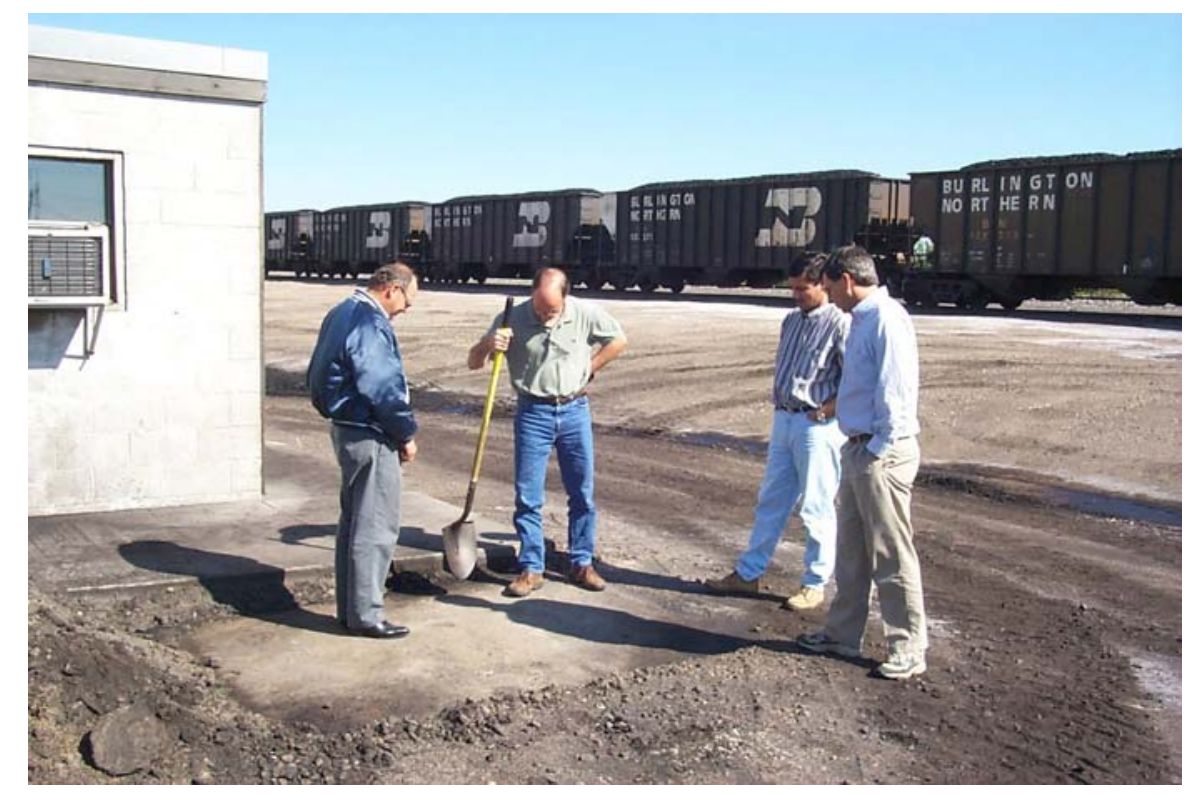

Figure 47. WRI, MDU, and NDDH Personnel Examine the Performance of the Ready-Fill Base Material at the MDU Heskett Station During One of the Monitoring Visits

A second application of the Ready-Fill S-grade product was demonstrated at the Krider Equipment site in Bismarck, North Dakota. The application at that site was for the construction of storm water drainage around the facility. The area for the storm drain was excavated and the E-grade Ready-Fill was placed in the excavated trench (Figure 48) and allowed to cure. The cured material was strong enough to support traffic that needed to cross the storm water drain, yet soft enough to be shaped with a grader blade to achieve the proper profile (Figure 49).

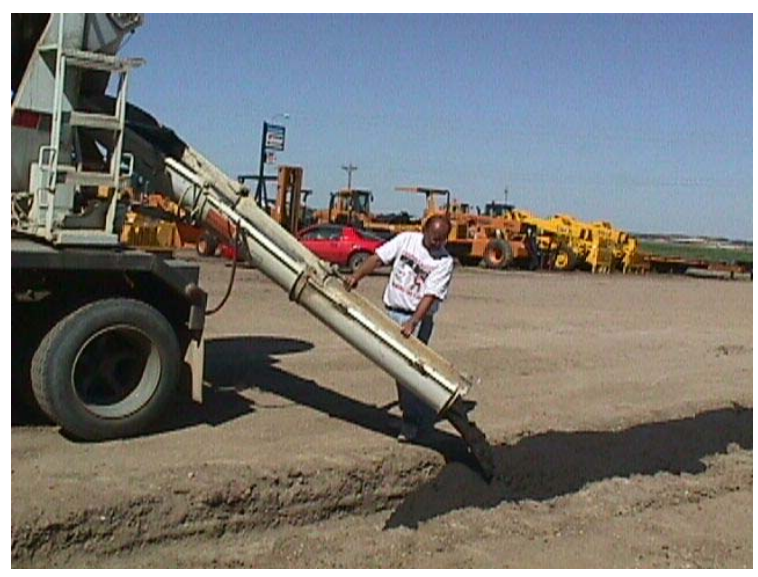

Figure 48. Placement of Ready-Fill at Krider Equipment Demonstration Site

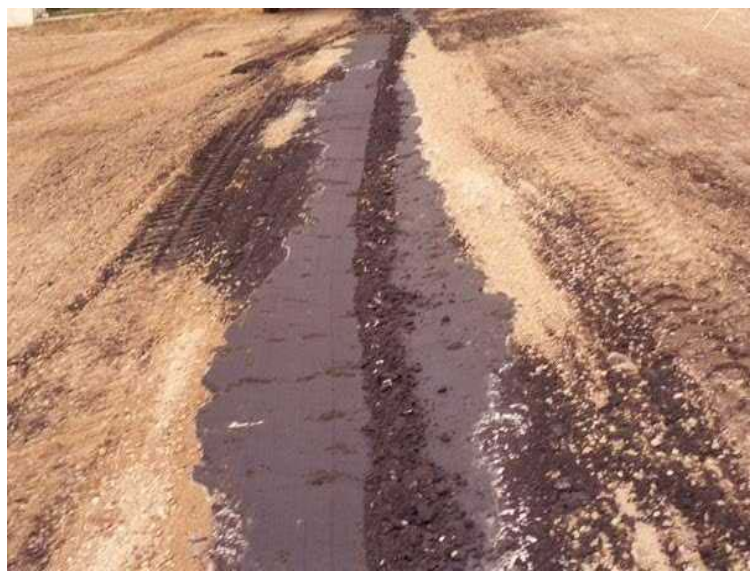

Figure 49. Blade-Shaped Ready-Fill Storm Water Drainage 


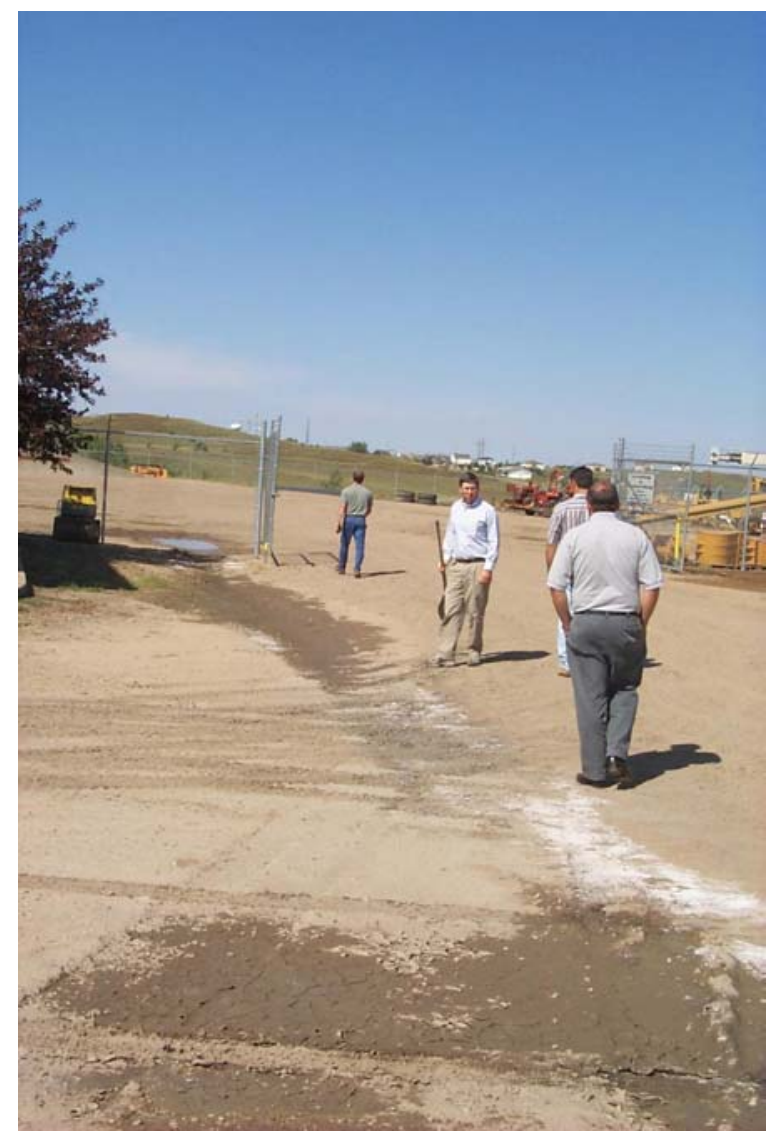

Figure 50. Monitoring the Storm Water Drainage Ditch Made From Ready-Fill at Krider Equipment

The site has been visually monitored (Figure 50) over a two-year period with some apparent softening of the surface in certain areas. The softening did not cause problems with the geotechnical performance; however, it did cause concern relative to possible leaching of components from the Ready-Fill into the environment. Samples of the material have been collected and analyzed for leachable metals by the NDDH. Additional samples of the S-grade and E-grade Ready-Fill were prepared and leachate analyses performed. The leaching procedure was modified at the request of the NDDH to reflect a 4:1 water to solid ratio instead of the standard 20:1 ratio specified in ASTM D-3987. A summary of these results is presented in Table 26. 
Table 26. Summary of the Ready-Fill Leachate Composition per Modified (4:1) ASTM D3987

\begin{tabular}{|c|c|c|c|c|c|}
\hline Test Description & $\begin{array}{c}\text { WRI/MVTL } \\
\text { Flowable Fill } \\
\text { D-3987 } \\
\text { 20:1 Extract }\end{array}$ & $\begin{array}{c}\text { E-Grade } \\
\text { Ready-Fill } \\
\text { D-3987 } \\
\text { 4:1 Extract }\end{array}$ & $\begin{array}{c}\text { S-Grade } \\
\text { Ready-Fill } \\
\text { D-3987 } \\
\text { 4:1 Extract }\end{array}$ & $\begin{array}{c}\text { EPA } \\
\text { Regulations } \\
\text { Domestic }\end{array}$ & $\begin{array}{l}\text { EPA } \\
\text { Regulations } \\
\text { Agriculture }\end{array}$ \\
\hline $\mathrm{pH}$ & 12.2 & 10.7 & 11.1 & $6.5-9.0$ & $4.5-9.0$ \\
\hline Total Dissolved Solids & 839 & 940 & 1,220 & 500 & 2,000 \\
\hline Specific Conductance & 3,070 & 1,610 & 2,670 & - & - \\
\hline Hydroxide & na & 76 & 350 & - & - \\
\hline Chloride & 4.2 & 1.4 & 3.6 & 250 & 100 \\
\hline Fluoride by IC & 0.16 & 0.43 & 0.49 & 2.4 & - \\
\hline Nitrate + Nitrite & $<1$ & 4.3 & 0.5 & & \\
\hline Sulfate by IC & 113 & 491 & 496 & 250 & 200 \\
\hline Phosphorous (Total) & na & $<0.1$ & $<0.1$ & - & - \\
\hline Sodium Adsorption Ratio & 1.34 & 6.6 & 18.6 & - & 8 \\
\hline Dissolved Metals, mg/L & & & & & \\
\hline Aluminum & 0.215 & 0.646 & 2.225 & - & 5 \\
\hline Antimony & na & $<0.002$ & $<0.002$ & - & - \\
\hline Arsenic & $<0.002$ & 0.0064 & 0.0076 & 0.05 & 0.1 \\
\hline Barium & 0.465 & 0.20 & 0.12 & 1 & - \\
\hline Beryllium & $<0.0002$ & $<0.0002$ & $<0.0002$ & - & 0.1 \\
\hline Boron & 0.14 & 0.76 & 0.42 & 0.75 & 0.75 \\
\hline Cadmium & $<0.0002$ & $<0.0002$ & $<0.0002$ & 0.01 & 0.01 \\
\hline Calcium & na & 94.6 & 33.7 & - & - \\
\hline Chromium & 0.19 & 0.0021 & 0.0091 & 0.05 & 0.1 \\
\hline Cobalt & $<0.002$ & $<0.1$ & $<0.1$ & - & 0.05 \\
\hline Copper & $<0.002$ & 0.0024 & 0.0037 & 1 & 0.2 \\
\hline Iron & $<0.002$ & $<0.1$ & $<0.1$ & 0.3 & 5 \\
\hline Lead & 0.0078 & $<0.002$ & $<0.002$ & 0.05 & 5 \\
\hline Magnesium & na & $<0.5$ & $<0.5$ & - & - \\
\hline Manganese & $<0.002$ & $<0.002$ & $<0.002$ & 0.05 & 0.2 \\
\hline Mercury & $<0.0002$ & $<0.0002$ & $<0.0002$ & 0.002 & - \\
\hline Nickel & $<0.002$ & 0.0042 & $<0.002$ & - & 0.02 \\
\hline Potassium & na & 11.3 & 23.5 & - & - \\
\hline Selenium & $<0.002$ & 0.0056 & 0.0099 & 0.01 & 0.02 \\
\hline Silica as $\mathrm{SiO}_{2}$ & na & 47.90 & 61.41 & - & - \\
\hline Silver & $<0.01$ & $<0.0002$ & $<0.0002$ & 0.05 & - \\
\hline Sodium & na & 234 & 397 & - & - \\
\hline Thallium & na & $<0.002$ & $<0.002$ & - & - \\
\hline Vanadium & $<0.002$ & 0.032 & 0.063 & - & 0.1 \\
\hline Zinc & 0.295 & 0.040 & 0.021 & 5 & 2 \\
\hline
\end{tabular}

na - not available but determined

nd - not determined

As shown in Table 26, the Ready-Fill meets the EPA (Environmental Protection Agency) Domestic and Agriculture Standards with the exception of $\mathrm{pH}$, sulfate, and marginally for SAR (Sodium Adsorption Ratio). If recalculated on the basis of 20:1 as per ASTM 3987, the leachates would meet the sulfate and SAR requirements as well. 
Ready-Fill is a versatile construction material and can be used in a number of niche applications and markets. Potential niche markets include: (1) housing construction industry use such as housing and patio sub-bases, backfill around poured basements, and crawl space construction; (2) erosion control and repair for a number of applications; and (3) even feedlot base material. Two of these niche markets were investigated and the use of Ready-Fill demonstrated. The first example of a niche use of Ready-Fill is for the repair and control of eroded areas. MDU was experiencing erosion behind a retaining wall at their Sweet Avenue electrical substation in Bismarck. Ready-Fill, due to its flow characteristics, made an ideal material to backfill the eroded area and prevent further erosion at the site (Figures 51 and 52).

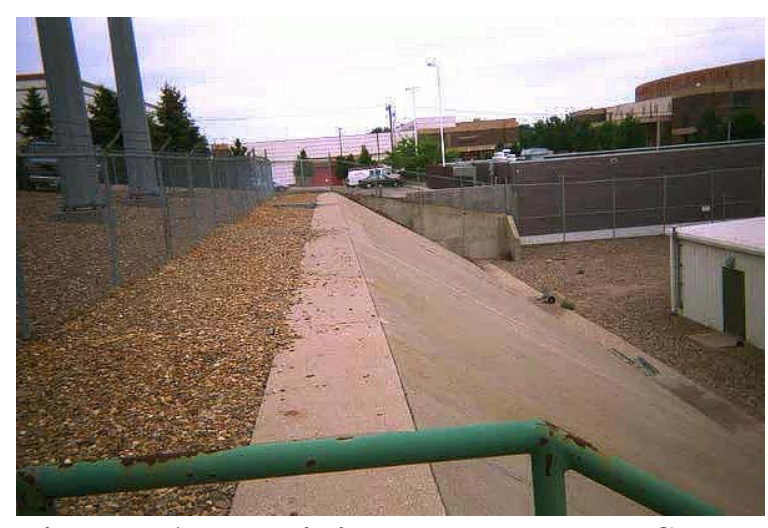

Figure 51. Retaining Wall at MDU Sweet Avenue Substation

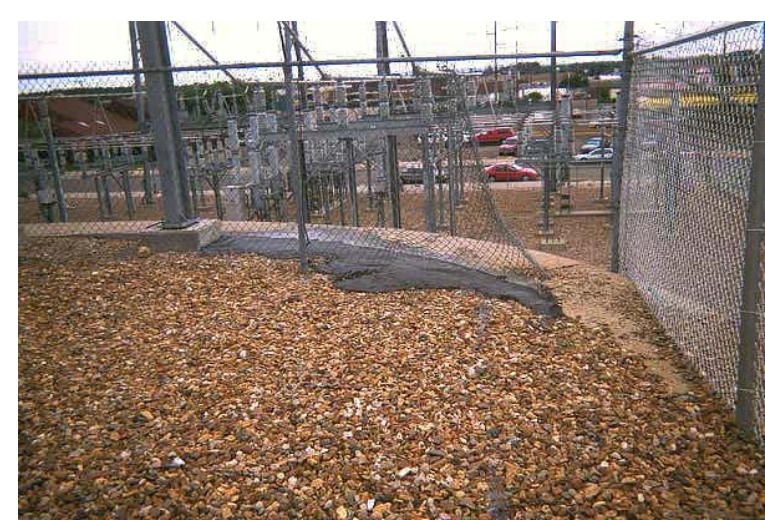

Figure 52. Poured Ready-Fill Repair at the MDU Sweet Avenue Substation

A second example of niche markets for the Ready-Fill material is its use as a base material for the construction of a residential bricked patio. Approximately 8 cubic yards of Ready-Fill product were placed as a base for the construction of the bricked patio at a subdivision in Bismarck. Figure 53 presents photographs showing this application. The product appears to be performing well in this application.
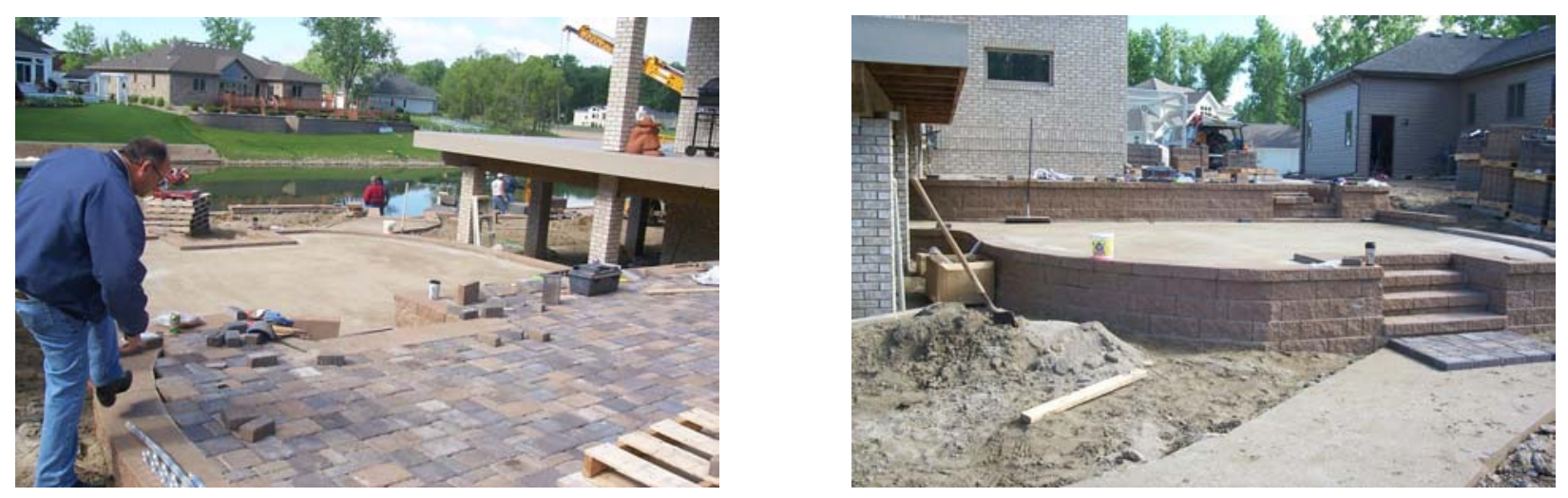

Figure 53. Photographs of the Use of Ready-Fill Product for Construction of a Bricked Residential Patio

Ready-Fill appears to be a versatile construction material with a wide range of applications ranging from excavatable to structural construction applications to a range of niche 
applications. WRI and MDU have entered into a joint venture to commercialize the MDU flowable fill material under the trade name of Ready-Fill. Ready-Fill is presently commercially available for a range of construction applications in the Bismarck-Mandan area of North Dakota. Ready-Fill is presently being wholesaled to one of the ready-mix concrete producers in Bismarck for transport to the job site. The price for Ready-Fill for the customer is in the range of \$30$35 \$ /$ cubic yard, which is competitive with other materials in the area. WRI and MDU, through this Ready-Fill joint venture, are currently pursuing conventional and new market applications for the Ready-Fill product.

In summary, the results of the second testing and demonstration activities proved the following:

- $\quad$ Ready-Fill can be produced in commercial-scale facilities using low-cost materials (sand and ash) that have geotechnical and environmental properties that meet industry needs.

- $\quad$ The geotechnical properties of the ash-based flowable fill (Ready-Fill) can be modified to meet the needs of a range of applications from structural fill applications to excavatable applications, such as utility trench fill.

- The environmental properties of the fill materials are compatible with numerous construction applications and do not pose a threat to either adjacent groundwater or soils.

- $\quad$ The demonstrations of Ready-Fill at a commercial scale were successful for excavatable, structural, as well as niche applications.

The Ready-Fill product appears to be a commercially viable option for the use of MDU ash in the Bismarck and Mandan area.

As a result of this project, new markets are commercially available for the ashes from the burning of lignite in fluidized-bed combustors. The state of North Dakota has benefited by establishing a commercial product for lignite-derived ash in flowable fill applications, thereby transforming a present waste product into a salable commodity in the construction industry and providing employment and economic growth. 


\section{REFERENCES}

Aubert, H. and M. Pinta, 1977, "Developments in Soil Science 7: Trace Elements in Soils." Elsevier, New York, 395 p.

Ferguson, J.E., 1990, “The Heavy Elements: Chemistry, Environmental Impact, and Health Effects." Chapter 9: Heavy Elements in Soils. Pergamon Press, New York.

Hutchinson, T. C. and K. M. Meema, 1987, Lead, Mercury, Cadmium and Arsenic in Environment. SCOPE 31 Report on the Scientific Committee on Problems of the Environment, John Wiley and Sons, New York.

Korcak, 1995, "Utilization of Coal Combustion By-Products in Agriculture and Horticulture," Chapter 6 in Agricultural Utilization of Urban and Industrial By-Products, American Society of Agronomy Special Publication No. 58, p. 107-130.

Mehta, P. K., 1986, Concrete, Structure, Properties and Materials, Prentice-Hall, Englewood Cliffs, NJ.

Portland Cement Association, "An Analysis of Selected Trace Metals in Cement and Kiln Dust," Portland Cement Association, Skokie, IL.

Smith, A. E., and J. B. Levenson, 1980, A Screening Procedure for the Impacts of Air Pollution Sources on Plants, Soils, and Animals. Report No EPA 450/2-81-078. U. S. Environmental Protection Agency, Office of Air Quality, Research Triangle Park, North Carolina.

Steen, D. O. and Bland, A. E., 2001, "Market Assessment and Demonstration of Lignite FBC Ash Flowable Fill Applications," Final Report to North Dakota Industrial Commission, Bismarck, ND, Contract No. NDIC FY97-XXVI-73, 61 pp. 


\section{BIBLIOGRAPHY}

Adaska, W.S. and W.C. Krell, 1992, "Bibliography on Controlled Low-Strength Materials (CLSM)," Concrete International, Vol. 14, No. 10, p. 42-43.

Ambroise, J., Amoura, A. and J. Pera, 1995, Development of Flowable High Volume-Fly Ash Mortars; In Proceedings of the 11th International Symposium on Use and Management of Coal Combustion By-Products (CCBs), American Coal Ash Association, EPRI TR104657, p.38-1 - 38-9.

American Concrete Institute, 1994, Controlled Low-Strength Material, ACI SP-150.

American Concrete Institute, 1994, "State-of-the-Art Report on Controlled Low Strength Materials (CLSM)," ACI Committee 229 Report.

ASTM, Annual Book of ASTM Standards, Philadelphia, PA.

Bacher, J. R. and R. L. Kolkka, 1991, "Design Applications with Flowable Fly Ash Backfill Indian River Power Station," In Proceedings of the 9th International Symposium on Ash Utilization, Orlando, FL, January, 1991, p. 7-1 to 7-15.

Balsamo, N., 1987, "Slurry Backfills - Useful and Versatile," Public Works, April, 1987, p. 5860.

Bhat, S.T., Lovell, C.W., Scholer, C.F. and T.E. Nantung, 1995, Flowable Fill Using Waste Foundry Sand, Proceedings of the 11th International Symposium on Use and Management of Coal Combustion By-Products (CCBs), American Coal Ash Association, EPRI TR-104657, p.39-1 - 39-14.

Bland, A.E., T.H. Brown, and D.O. Steen, 2001, Ready-Fill - Flowable Fill Materials Made from Lignite-Fired Fluidized Bed Combustion Ash," Proceedings: International Symposium on Management and Use of Coal Combustion Products (CCPs), American Coal Ash Association, Alexandria, VA, San Antonio, TX, January 23-26, 2001, pp 40-1 -40-19.

Bland, A.E., T.H. Brown, and D.O. Steen, 2001, "Ready-Fill - A Versatile FBC Ash-Based Construction Material," Proceedings: $16^{\text {th }}$ International Conference on Fluidized Bed Combustion, Reno, NV, May 13-16, 2001, pp. 200-1 - 200-18. 


\section{BIBLIOGRAPHY (continued)}

Brendel, G. F., N. J. Balsamo and P. E. Glogowski, 1987, “An Overview of the Use of Fly Ash in Slurried Placement Applications," In Proceedings of the 8th International Symposium on Ash Utilization, Washington, DC, October, 1987, p. 10-1 to 10-9.

Brewer, W.E., Schroeder, M. and D. Hirsch, 1995, Results of the Georgetown, Ohio Pavement Research Using Controlled Low Strength Material - Controlled Pavement Base, In Proceedings of the 11th International Symposium on Use and Management of Coal Combustion By-Products (CCBs), American Coal Ash Association, EPRI TR-104657, p.42-1 - 42-12.

Brewer, W. E., 1992, “An Assemblage of Five Reports on the Subject of Controlled Low Strength Material (CLSM)," Cincinnati Gas and Electric Company, Cincinnati, Ohio.

Collins, R. J., J. J. Colussi and L. M. Ruggiano, 1991, "Physical Considerations in the Design, Mixing and Placement of Flowable Fill Materials," In Proceedings of the 9th International Symposium on Ash Utilization, Orlando, FL, January, 1991, p. 6-1 to 6-14.

Electric Power Research Institute, 1988, “Laboratory Testing of Fly Ash Slurry,” Electric Power Research Institute, Report No. CS-6100, Palo Alto, CA, December 1988, 484 pp.

Fuston, J. J., W. C. Krell, and F. V. Zimmer, 1984, "Flowable Fly Ash: A New Cement Stabilized Backfill,” ASCE, Civil Engineering, March 1984, p. 48-51.

Grace Construction Products, 1996, "Darafill, Flowable Fill Performance Additive," W.R. Grace Co., Bedford Park, Illinois.

Korcak, 1995, "Utilization of Coal Combustion By-Products in Agriculture and Horticulture," Chapter 6 in Agricultural Utilization of Urban and Industrial By-Products, American Society of Agronomy Special Publication No. 58, p. 107-130.

Kuloszewski, J.A., 1995, "Strength Testing of Flowable Ash Mixtures," In Proceedings of the 11th International Symposium on Use and Management of Coal Combustion By-Products (CCBs), American Coal Ash Association, EPRI TR-104657, p.40-1 -40-10.

Larsen, R. L., 1990, “Sound Uses of CLSM's in the Environment," Concrete International, July 1990, p. 26-29. 
Maher, M. H. and P. N. Balaguru, 1991, "Mechanical Properties of Low Strength, High Volume Fly Ash Mortar"; In Proceedings of the 9th International Symposium on Ash Utilization, Orlando, FL, January, 1991, p. 8-1 to 8-17.

BIBLIOGRAPHY (continued)

McLaren, R. J., and N. J. Balsamo, 1989, "Fly Ash Design Manual for Road and Site Applications. Volume 2. Slurried Placement," Electric Power Research Institute, Report No.CS-4419, Palo Alto, CA, October, 1989.

Mings, M. L., 1985, "Pipe Bedding with Class 'C' Fly Ash Grout"; In Proceedings of the 7th International Ash Utilization Symposium and Exposition, Orlando, FL, March 4-7, 1985, Volume I, DOE/METC-85/6018.

Naik, T. R., L. E. Sohns, and B. W. Ramme, 1991, "Controlled Low Strength Material (CLSM) Produced with High-Lime Fly Ash," In Proceedings of the 9th International Symposium on Ash Utilization, Orlando, FL, January, 1991, p. 9-1 to 9-18.

Naik, T. R., B. W. Ramme and H. J., Kolbeck, 1990, "Filling Abandoned Underground Facilities with CLSM Fly Ash Slurry," Concrete International, July, 1990, p. 19-25.

Nantung, T.E., 1993, "Design Criteria for Controlled Low Strength Materials," Ph.D. Thesis, Purdue University.

National Ready Mix Concrete Association, "Ready Mixed Flowable Fill - A Controlled Density Material," NRMCA Publication MSP36, 4 pp.

Newman, F.B., DiGioia, Jr., A.M. and L.F. Rojas-Gonzalez, 1995, “CLSM Backfills for Bridge Abutments," In Proceedings of the 11th International Symposium on Use and Management of Coal Combustion By-Products (CCBs), American Coal Ash Association, EPRI TR-104657, p.4-1 -41-19.

Newman, F.B., Rojas-Gonzalez, L.F. and D.L. Knott, 1992, "Current Practice in Design and Use of Flowable Backfills for Highway and Bridge Construction," Pennsylvania Department of Transportation Research Project 90-12.

Russ, W. E., 1987, "Flowable Mortar in Iowa," In Proceedings of the 8th International Symposium on Ash Utilization, Washington, DC, October, 1987, p. 11-1 to 11-17.

Swaffer, K. M. and H. R. Price, 1987, “Tunnel Saved By Fly Ash,” ASCE, Civil Engineering, September 1987, p. 69-70. 
Torrey, S. 1978, "Fly Ash, Bottom Ash and Slag - The K-Krete Story," Noyes Data Corporation, 1978, p. 119-122.

\section{BIBLIOGRAPHY (continued)}

Weber, L., 1987, "Controlled Density Low Strength Material Backfill in Illinois," In Proceedings of the 8th International Symposium on Ash Utilization, Washington, DC, January, 1987, p. 12-1 to 12-13. 


\section{APPENDIX A}

CHEMICAL COMPOSITION DATA 
Attachment A-1.

MDU Fly Ash and Flowable Fill - ASTM D-3987 Extract Composition

\begin{tabular}{|lcc|}
\hline & $\begin{array}{c}\text { MDU Fly Ash } \\
\text { D-3987-85 }\end{array}$ & $\begin{array}{c}\text { MDU Flowable Fill } \\
\text { D-3987-85 }\end{array}$ \\
\hline & Extract & Extract \\
\hline pH & 12.7 & 12.2 \\
TDS & 6240 & 839 \\
Specific Conductance, umhos/cm & 140,900 & 3,070 \\
pH $(\mathrm{D}-3987-85$ Shake Extraction) & 12.5 & 12.1 \\
\% Solids $(\mathrm{D}-3987-85$ Shake Extraction) & 99.7 & 94.6 \\
\hline Total Alkalinity, mg/L CaCO3 & 3,000 & 676 \\
Phenolphthalein Alkalinity, mg/L CaCO3 & 2,940 & 661 \\
Bicarbonate, mg/L CaCO3 & $<1$ & $<1$ \\
Carbonate, mg/L CaCO3 & 120 & 30 \\
Hydroxide, mg/L CaCO3 & 2,880 & 646 \\
Total Hardness as CaCO3 & 3,120 & 559 \\
Hardness in grains/gal & 183 & 32.7 \\
\hline Fluoride, $\mathrm{mg} / \mathrm{L}$ & 2.03 & 0.16 \\
Chloride, $\mathrm{mg} / \mathrm{L}$ & 28.0 & 4.2 \\
Sulfate, $\mathrm{mg} / \mathrm{L}$ & 2,260 & 113 \\
Nitrate - Nitrite as N, mg/L & 1.8 & $<1$ \\
Nitrite as N, mg/L & $<0.2$ & $<0.2$ \\
Phosphorous as P Total, mg/L & $<0.1$ & $<0.1$ \\
\hline Aluminum, mg/L & 0.120 & 0.215 \\
Silicon, mg/L & 0.31 & 1.8 \\
Iron, mg/L & $<0.002$ & $<0.002$ \\
Calcium, mg/L & 1,250 & 224 \\
Sodium, mg/L & 856 & 72.8 \\
Potassium, mg/L & 41.1 & 19.0 \\
Magnesium, mg/L & $<0.5$ & $<0.5$ \\
Manganese, mg/L & $<0.002$ & 14.8 \\
\hline Cation Sum & 101.0 & 16.0 \\
Anion Sum & 108.0 & -3.77 \\
Percent Error & -3.50 & 1.34 \\
SAR & 6.66 & \\
\hline
\end{tabular}


Attachment A-2.

MDU Fly Ash and Flowable Fill - ASTM D-3987 Extract Composition

\begin{tabular}{|lcc|}
\hline & $\begin{array}{c}\text { MDU Fly Ash } \\
\text { D-3987-85 }\end{array}$ & $\begin{array}{c}\text { MDU Flowable Fill } \\
\text { D-3987-85 }\end{array}$ \\
\hline Trace Metals, ug/L & Extract & Extract \\
\hline Antimony & $<0.002$ & $<0.002$ \\
Arsenic & $<0.002$ & $<0.002$ \\
Barium & 0.215 & 0.465 \\
Berylium & $<0.0002$ & $<0.0002$ \\
Boron & 0.45 & 0.14 \\
Cadmium & $<0.0002$ & $<0.0002$ \\
Chromium & 0.0090 & 0.0190 \\
Cobalt & $<0.002$ & $<0.002$ \\
Copper & $<0.002$ & $<0.002$ \\
Lead & 0.0111 & 0.0078 \\
Mercury & $<0.0002$ & $<0.0002$ \\
Molybdenum & 0.182 & 0.022 \\
Nickel & $<0.002$ & $<0.002$ \\
Selenium & 0.0149 & $<0.002$ \\
Silver & $<0.01$ & $<0.01$ \\
Strontium & 27.01 & 3.28 \\
Thallium & $<0.002$ & 0.0157 \\
Titanium & $<0.01$ & $<0.002$ \\
Vanadium & $<0.002$ & $<0.002$ \\
Zinc & 0.970 & 0.295 \\
\hline Radioactivity (pCi/g) & & $<0.0003$ \\
Uranium & $<0.0003$ & $<1$ \\
Gross Alpha & $<1$ & $<1$ \\
Radium 226 & $<0.2$ & $<1.2$ \\
Radium 228 & $<1$ & \\
Comb. Ra226+228 & $<1.2$ & \\
\hline & & \\
\hline
\end{tabular}

